Plastic ingestion, retention, and transport in animals from the eastern Canadian Arctic

by

\title{
Madelaine Bourdages
}

A thesis submitted to the Faculty of Graduate and Postdoctoral Affairs in partial fulfillment of the requirements

for the degree of

\author{
Master of Science \\ in
}

Geography

Carleton University

Ottawa, Ontario

(C) 2020

Madelaine Bourdages 


\begin{abstract}
Plastic and microplastic pollution has been recognized as a global concern. I aimed to assess the retention and transport of plastic pollution in the Canadian Arctic using two important animals from the Arctic ecosystem: seals and seabirds. First, I examined 142 seal stomachs from four communities in the eastern Canadian Arctic to identify whether seals are accumulating plastics in their stomachs. No evidence of accumulated plastic debris in seal stomachs was found, suggesting that seals in the eastern Canadian Arctic are likely not exposed to plastics during foraging. Second, the faecal precursors of northern fulmars (Fulmarus glacialis) and thick-billed murres (Uria lomvia) were examined to identify if these birds are excreting microplastics in their guano. Anthropogenic particles were found in both species, however, there was no relationship between the microplastic particles in the faecal precursors and plastic debris found in the stomachs of the same birds.
\end{abstract}




\section{Preface}

A version of Chapter 3 has been published in Marine Pollution Bulletin (Bourdages, M.P.T., Provencher, J.F., Sudlovenick, E., Ferguson, S.H., Young, B.G., Pelletier, N., Murphy, M.J.J., D’Addario, A., Vermaire, J.C., 2020. No plastics detected in seal (Phocidae) stomachs harvested in the eastern Canadian Arctic. Mar. Pollut. Bull. 150, 1-5. https://doi.org/10.1016/j.marpolbul. 2019.110772). The published article is reproduced in full with minor changes including the placement of figures and tables within the text, figure and table numbering to correspond with thesis formatting, and reference to thesis appendices for supplementary material. I was the lead investigator for this project, and was responsible for all major areas of project conceptualization, data collection and analysis, data curation, and writing of the original manuscript. E.

Sudlovenick, was involved in project conceptualization, participated in the collection of field data, and contributed to manuscript edits. S.H. Ferguson and B.G. Young were involved in project conceptualization, funding acquisition, and contributed to manuscript edits. N. Pelletier, M.J.J. Murphy, and A. D’Addario helped with stomach dissections and contributed manuscript edits. J.F. Provencher and J.C. Vermaire supervised this project and were both involved with conceptualization, funding acquisition, providing advice throughout the project, and manuscript edits.

Chapter 4 has been submitted for publication to Science of the Total Environment - Plastic Pollution in the Arctic special issue. I was the lead investigator for this project, and was responsible for all major areas of project conceptualization, data collection and analysis, data curation, and writing of the original manuscript. J.E. Baak provided data for the bird morphometric features and dissection data for the bird gastrointestinal tracts, and contributed to manuscript edits. M.L. Mallory was involved in conceptualization of the study, funding 
acquisition, and contributed to manuscript edits. J.F. Provencher and J.C. Vermaire supervised this project and were both involved with conceptualization, funding acquisition, providing advice throughout the project, and manuscript edits.

Madelaine P.T. Bourdages Signature
July 25,2020

Date

We are in agreement with the above contribution statement.

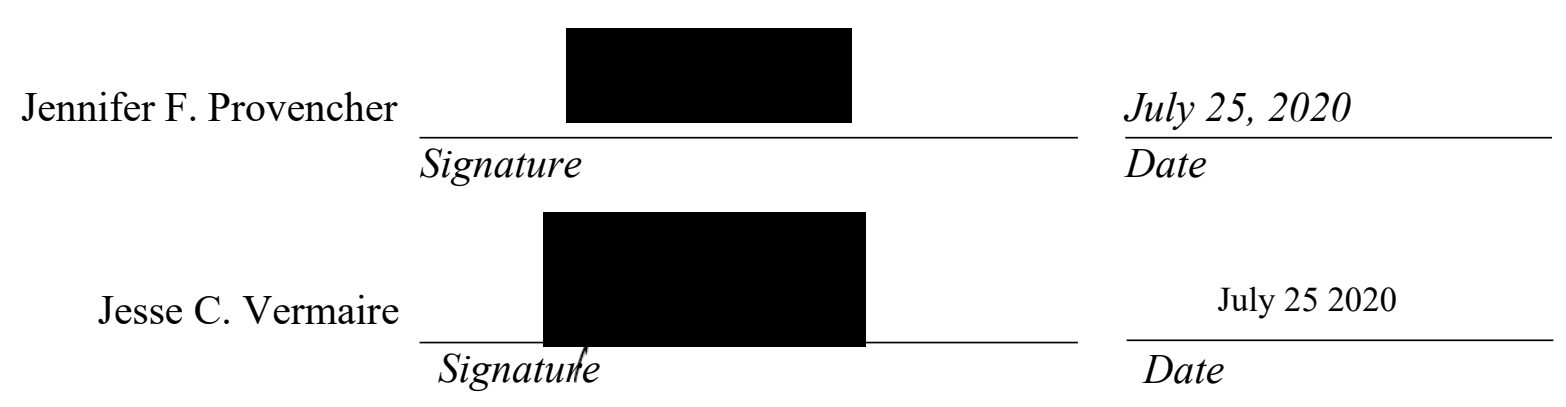




\section{Acknowledgements}

I would like to thank everyone that helped and supported me along the way to completing my Master's. I would especially like to thank Dr. Jesse Vermaire for his continued support, guidance, and for the many research and networking opportunities he has given me throughout the past two years. I would also like to thank Dr. Jennifer Provencher for her guidance and for opening the door to Arctic research. I am immensely grateful for the opportunity to conduct research in the Arctic, and I look forward to continuing with similar work. Working with both of you has been an incredible learning opportunity, and I look forward to continuing to work and collaborate with you.

Thank you to all of the faculty, staff, and graduate students in my program and in my lab that provided both academic and emotional support throughout my Master's. I would especially like to thank Lindsay Trottier, Emma Stockton, and Patrick Beaupre for their support. Whether it was company during long days of working on campus, talking through problems with data and statistics, or social outings to take our minds off of our work, these past two years would have been much harder and less enjoyable without you.

Finally, I would like to thank my friends and family for always supporting me and for patiently listening to me lecture about plastic pollution. To my parents, Pamela and Mike Bourdages, thank you for instilling in me my love for the environment and for always supporting me and encouraging me to follow my dreams and goals. I would not be where I am today without your guidance and support. 


\section{Table of Contents}

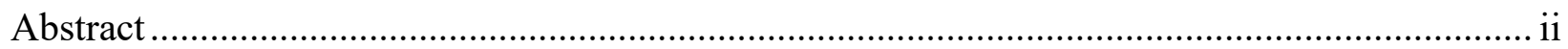

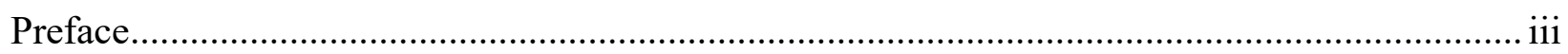

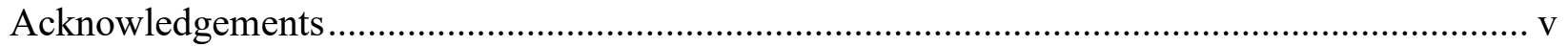

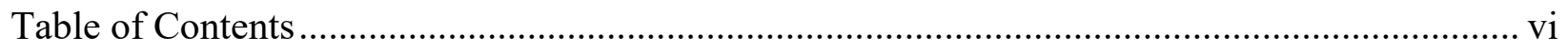

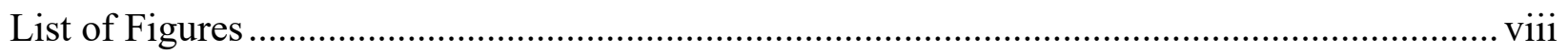

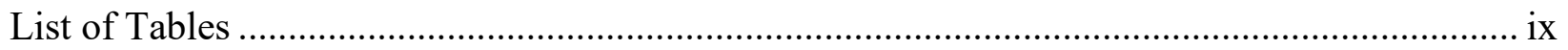

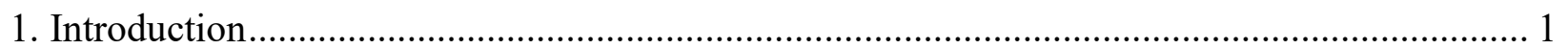

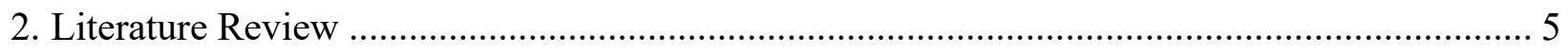

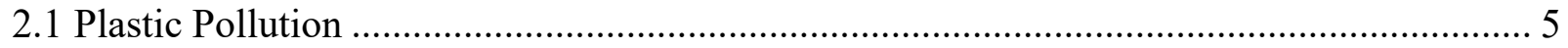

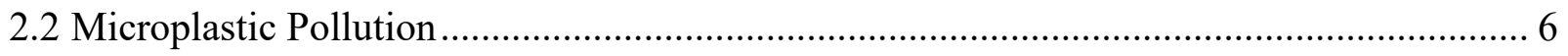

2.3 Sources, Drivers, and Distribution of Plastic and Microplastic Pollution in the Environment

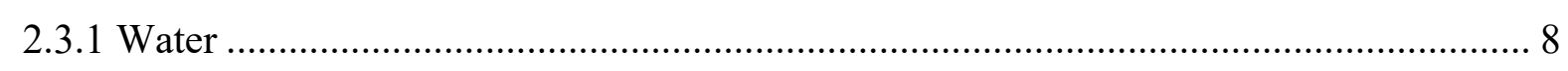

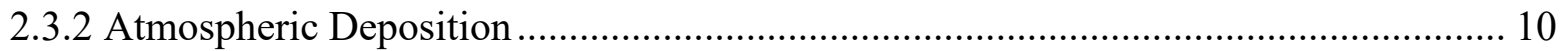

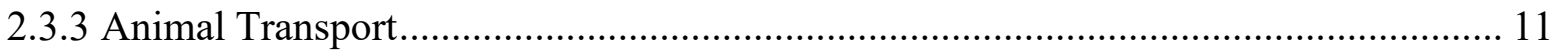

2.4 Consequences of Plastic Pollution ........................................................................... 12

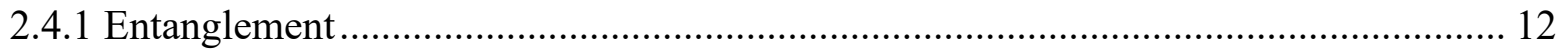

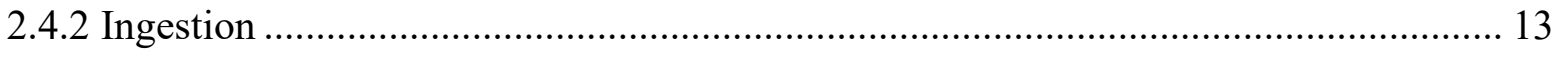

2.4.2.1 Ingestion of Plastic Pollution by Marine Mammals.......................................... 14

2.4.2.2 Ingestion of Plastic Pollution by Seabirds ........................................................ 17

2.4.3 Chemical \& Toxin Transfer.......................................................................... 21

2.5 Methods Used to Research Plastic Pollution in Animals ............................................... 21

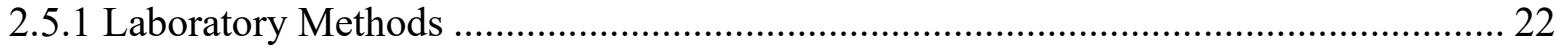

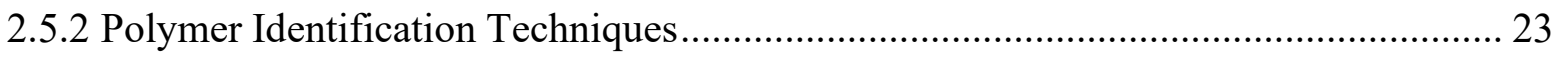

3. No Plastics Detected in Seal (Phocidae) Stomachs Harvested in the Eastern Canadian Arctic 25

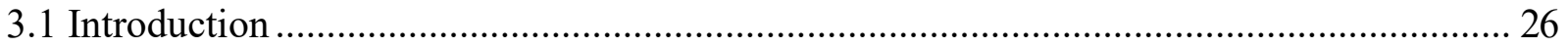

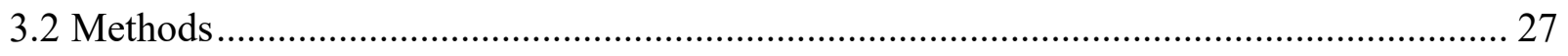

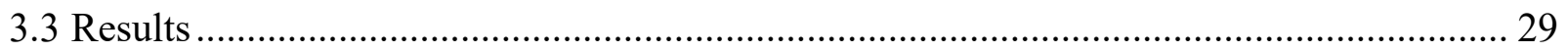

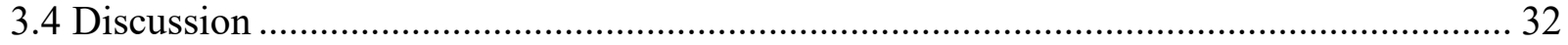

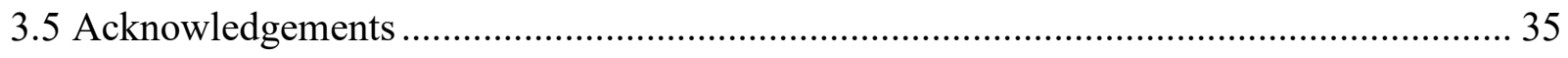


4. Breeding Seabirds as Vectors of Microplastics From Sea to Land: Evidence From Colonies in

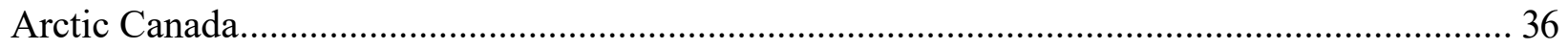

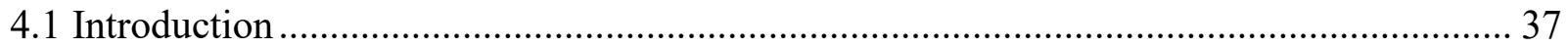

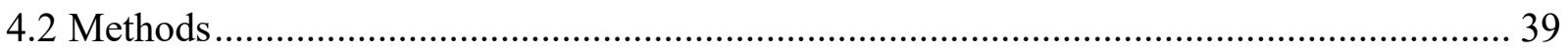

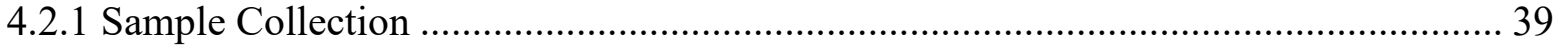

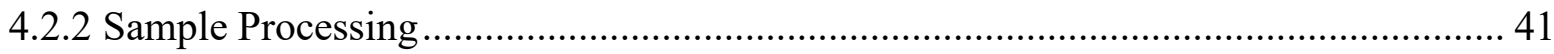

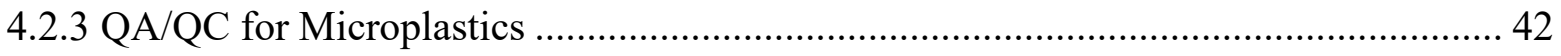

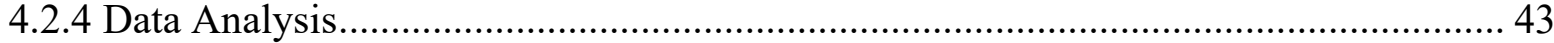

4.2.5 Estimates of Microplastics Deposited Around the Colonies .................................. 43

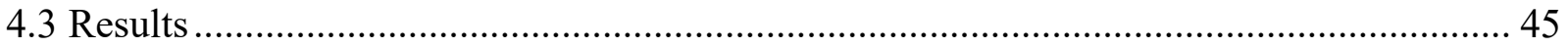

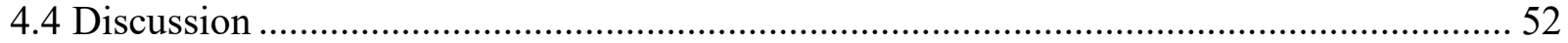

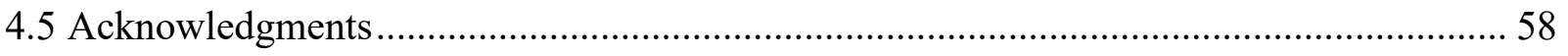

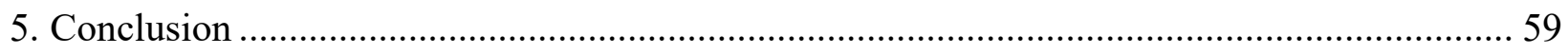

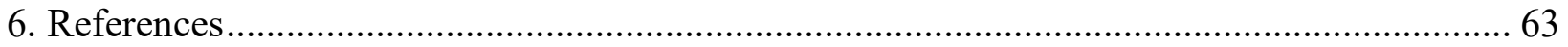

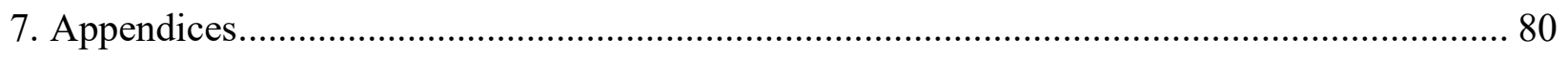

A. Review of Marine Debris Ingestion by Marine Mammals .......................................... 80

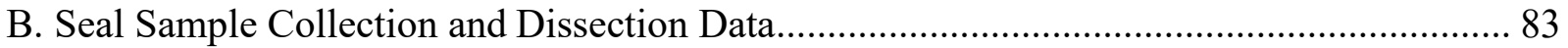

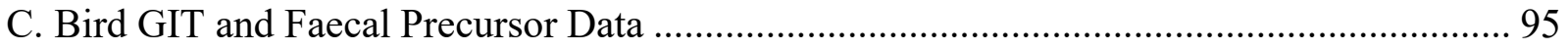




\section{List of Figures}

Figure 2.1: The gastrointestinal tract of a northern fulmar (Fulmarus glacialis). Hard, ingested material, including plastics, typically accumulate in the muscular gizzard where they are mechanically ground up until they are small enough to move through the intestines and be excreted via the cloaca. Bird stomachs, including the proventiculus and the gizzard are typically dissected in plastic ingestion studies, however, the faecal precursor samples (cloaca and a section of the small intestine) are useful to assess concentrations of excreted microplastics. Figure taken from Provencher et al. (2018) and reprinted with permission from Elsevier..... 20

Figure 3.1: Locations in Nunavut, Canada, where Inuit subsistence hunters collected seal stomachs for this study: Arviat $\left(61.1078^{\circ} \mathrm{N}, 94.0624^{\circ} \mathrm{W}\right)$; Naujaat $\left(66.5283^{\circ} \mathrm{N}, 86.2447^{\circ} \mathrm{W}\right)$; Sanikiluaq $\left(56.5408^{\circ} \mathrm{N}, 79.2232^{\circ} \mathrm{W}\right)$; and Iqaluit $\left(63.7467^{\circ} \mathrm{N}, 68.5170^{\circ} \mathrm{W}\right)$. The numbers of seals collected from each location are indicated on the map. 28

Figure 3.2: Stomach contents from the 142 seals examined for this study. A: the frequency distribution of dominant stomach contents from the 142 seals. B: the dominant stomach contents observed during dissections, including euphausiids (I), fish (II), roundworms (III), kelp (IV), and rocks (V). (VI) shows the large rocks removed from the same stomach shown in (V) 31 Figure 4.1: Map showing the Qaqulluit and Akpait National Wildlife Areas (NWA) located near Qikiqtarjuaq, Nunavut in the eastern Canadian Arctic. In August 2018, northern fulmars were collected from the Qaqulluit NWA $\left(67.2333^{\circ} \mathrm{N}, 62.4667^{\circ} \mathrm{W}\right)$ and thick-billed murres were collected from the Akpait NWA $\left(66.9333^{\circ} \mathrm{N}, 61.7667^{\circ} \mathrm{W}\right)$

Figure 4.2: Distribution of particle shape categories from the stomach and faecal precursor samples of northern fulmars (NOFU) and thick-billed murres (TBMU), with (A) showing the count of particles and (B) showing the proportion of particles.... 46

Figure 4.3: Shape categories, colours, and chemical classifications of particles recovered from the faecal precursor samples of northern fulmars. Examples of spectral matches from microRaman spectroscopy are provided for different chemical classification types. Each black wavelength represents a sample particle spectrum and each red wavelength represents a known spectrum from the spectral libraries. The x-axes show the wavelengths $\left(\mathrm{cm}^{-1}\right)$ and the $y$-axes show the Raman intensity.

Figure 4.4: Shape categories, colours, and chemical classifications of particles recovered from the faecal precursor samples of thick-billed murres. Examples of spectral matches from microRaman spectroscopy are provided for different chemical classification types. Each black wavelength represents a sample particle spectrum and each red wavelength represents a known spectrum from the spectral libraries. The $\mathrm{x}$-axes show the wavelengths $\left(\mathrm{cm}^{-1}\right)$ and the $\mathrm{y}$-axes show

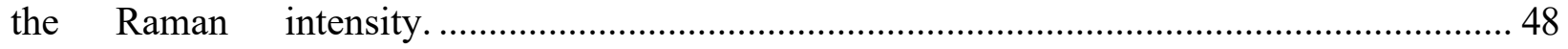

Figure 4.5: Examples of anthropogenic particles recovered from the faecal precursor samples of northern fulmars (A-B) and thick-billed murres (C-D). A: a blue synthetic dye fibre, an anthropogenic unknown fibre, and a blue polyethylene fragment. B: a white polyester fibre and two blue synthetic dye fibres. C: a blue polyethylene fragment. D: an acrylic yellow fibre 50 


\section{List of Tables}

Table 3.1: Distribution of species and sex of seals harvested from four communities in Nunavut, Canada between 2007 and 2019. 30

Table 4.1: Count, frequency of occurrence (with Jeffreys 95\% confidence interval), mean, median, and range of all anthropogenic particles and different categories of particles recovered from the stomachs (Baak et al., 2020) and faecal precursor samples of northern fulmars and thick-billed murres collected in August 2018 from two colonies near Qikiqtarjuaq, Nunavut .... 49 Table 4.2: Calculations for estimating the potential deposition of anthropogenic particles via guano for northern fulmars (NOFU) and thick-billed murres (TBMU) during the breeding season at colonies near Qikiqtarjuaq, Nunavut

Table 7.1: Summary of a selection of studies reporting on the ingestion of anthropogenic debris by marine mammals

Table 7.2: Supplementary data including field measurements and dissection data of collected seal.

Table 7.3: Counts and shape categories of plastics in gastrointestinal tracts and anthropogenic particles in guano samples for northern fulmars (NOFU) and thick-billed murres (TBMU) ....... 95

Table 7.4: Shape, colour, and polymer classification of anthropogenic particles found in northern fulmar (NOFU) and thick-billed murre (TBMU) faecal precursors from colonies near Qikiqtarjuaq, NU 


\section{Introduction}

Plastics are immensely useful, however, as a consequence of their ubiquity in society, plastic pollution, which defines discarded plastics that have entered the environment outside of established waste management (ECCC, 2020), has been documented in nearly every environment on Earth. Since the start of large-scale production of plastics in the 1950s, humans have produced immense amounts of plastic material, many of which have been intended for single use and have been discarded almost immediately after use (Geyer et al., 2017). Bodies of water including lakes, rivers, and oceans have, for a long time, been used as convenient locations for waste disposal, and out of all anthropogenic material entering these waters, plastics are considered to be the most problematic given their persistence in the environment (GESAMP, 2015). The first major concerns surrounding plastic debris in aquatic environments were focused on large plastic material ( $>5 \mathrm{~mm})$ - referred to as macroplastics - after reports were made of the deleterious effects floating debris was having on marine animals, including entanglement and suffocation (Browne et al., 2007; Derraik, 2002; GESAMP, 2015). Although initial accounts of small plastic debris floating in oceanic waters were published in the early 1970s (Carpenter et al., 1972; Carpenter and Smith, 1972), it is only more recently that small plastic pollution has received greater international attention as an emerging contaminant (Browne et al., 2007).

Plastics do not biodegrade but many can breakup into smaller fragments that can be easily transported throughout the environment (Barnes et al., 2009). Microplastics, which are defined as plastic particles smaller than five millimeters (Arthur and Baker, 2011), can enter the environment through various different sources and are of particular concern as they can be ingested by many organisms, causing a range of harmful effects (Browne et al., 2007). Some have even suggested that the extent of plastic pollution is so pervasive that plastic particles in the 
Earth's sediment can be used as indicators for the onset of the Anthropocene, a newly proposed geological Epoch where humans are influencing Earth system processes (Zalasiewicz et al., 2016). The presence and distribution of plastic and microplastic pollution throughout the environment highlights how humans alter the physical and biological conditions of the Earth's surface.

Although plastic pollution is increasingly being reported in many environments around the world, there has been less overall work conducted in the Arctic than in temperate regions (Halsband and Herzke, 2019). However, plastic and microplastic pollution has been reported in various Arctic environmental matrices such as surface waters (Huntington et al., 2020; Lusher et al., 2015b), deep-sea sediments (Bergmann et al., 2017), sea ice (Obbard et al., 2014; Peeken et al., 2018), and snow (Bergmann et al., 2019; Huntington et al., 2020). There have also been numerous studies that have reported on the ingestion of plastics by certain species of Arctic seabirds (Provencher et al., 2017), however, mammals in the Arctic have been understudied for plastic ingestion. The Arctic Ocean has been suggested as an accumulation point for plastic pollution (Cózar et al., 2017), and as such, understanding the distribution and fate of plastic pollution in the Arctic is increasingly becoming a research priority (e.g. Protection of the Arctic Marine Environment (PAME), 2019).

The overarching research objective of my thesis was to assess the retention and transport of plastic pollution in the Canadian Arctic using two key groups of Arctic animals: seals and seabirds. Although seabirds are known to ingest plastics, little is known about the ingestion and retention of plastics by Arctic mammals such as seals. Furthermore, how seabirds known to ingest plastic pollution may be acting as vectors of microplastics has yet to be fully examined. 
The ways in which these animals interact with plastic pollution provide insight into environmental concentrations of this pollutant, as well as help narrow future research priorities.

To meet these objectives, in Chapter 3, I investigated whether seals collected from four communities in the eastern Canadian Arctic were ingesting and retaining plastics in their stomachs. Through this collaborative project with Inuit hunters, I examined the stomach contents of 142 seals (ringed seals [Phoca hispida; $n=135$ ], bearded seals [Erignathus barbatus; $n=6$ ], and a harbour seal [Phoca vitualina; $n=1$ ]) that were hunted between 2007 and 2019 from communities in Nunavut. Seals are an important part of the Arctic ecosystem and make up an important portion of the diets of Inuit. Seals hold high cultural, social, and economic value for many northern communities (Searles, 2019), and as such, it is critical to examine plastic ingestion and accumulation in species that may result in negative effects on wildlife. The main objective of this chapter was to assess whether seals in the eastern Canadian Arctic are ingesting and retaining plastics (>425 $\mu \mathrm{m}$ ) in their stomachs. These data provide important baseline information for future plastic pollution monitoring programs in the Arctic.

In Chapter 4, I analysed the faecal precursors (the last approximately $10 \mathrm{~cm}$ of intestine including the cloaca) of two species of Arctic colonial seabirds - northern fulmars (Fulmaris glacialis; $n=27$ ) and thick-billed murres (Uria lomvia; $n=30$ ) - from two National Wildlife Areas on eastern Baffin Island, Nunavut. The objectives of this project were to assess if these seabirds are excreting microplastics via their guano, and if there was a relationship between plastics found in their gastrointestinal tracts and guano. In this study, I also used colony population data from 2018 (Mallory et al., 2020a), and the proportion of birds containing anthropogenic particles in their faecal precursor samples to estimate how many microplastic 
particles could potentially be deposited through guano to remote Arctic islands each year during the breeding periods.

This thesis provides important information on the interaction with, and current threat, plastic pollution may pose to two key animal groups in the eastern Canadian Arctic. As Canada continues to work with its international partners to tackle the problem of plastic pollution, the studies from this thesis provide policy makers with important information on current environmental concentrations of plastic and microplastic pollution, and fill knowledge gaps on methods for monitoring plastic and microplastic pollution. This thesis is presented as an integrated thesis. Chapter 1 provides a brief introduction to the thesis and to the topic of plastic pollution in the Arctic. Chapter 2 is a literature review that discusses plastic and microplastic pollution in the environment and how plastic pollution has been shown to interact with wildlife. My literature review focusses on the Arctic environment, while highlighting the need for further research on plastic pollution in the Arctic. Chapter 3, focusing on plastic ingestion and retention by seals, was published in Marine Pollution Bulletin (Bourdages et al., 2020). Chapter 4, investigating microplastic ingestion and dispersal in seabirds, was submitted in July 2020 as a research paper to a special issue on Plastic Pollution in the Arctic in the journal Science of the Total Environment. Chapter 5 summarizes the conclusions from the research conducted for this thesis. 


\section{Literature Review}

Plastic pollution has become a widespread concern around the world, and there are many studies aiming to understand environmental concentrations of this emerging pollutant as well as its effects on the environment. The field of plastic pollution is still considered to be in its infancy, and as such, definitions and research methods connected to plastic pollution continue to evolve as increased research continues on the topic (Hartmann et al., 2019). Although the number of studies are increasing, less is known about plastic pollution in the Arctic (Halsband and Herzke, 2019). Researching plastic pollution in the Arctic is particularly imperative given that the Arctic supports many ecologically and economically important species, and the overall Arctic environment is greatly relied upon by northern communities (Lusher et al., 2015b).

\subsection{Plastic Pollution}

Plastics are viewed as an incredibly beneficial material, particularly within the medical and food industries, however, increased waste production and improper waste management of plastics can negatively impact the environment. Even though large-scale production of plastics only dates back to the 1950s (Geyer et al., 2017), plastic material is so ubiquitous that it is difficult to imagine a society that does not rely on plastics. According to PlasticsEurope (2019, 2008), global production of plastic resins and fibres increased from approximately $1.5 \mathrm{Mt}$ in 1950 to more than $360 \mathrm{Mt}$ in 2018 . Virgin polymers are rarely used on their own, and instead, plastics are typically manufactured by combining polymers with a variety of additives (Thompson et al., 2009). The additives (e.g. plasticizers, stabilizers, and flame retardants) used in plastic manufacturing alter the plastics to achieve certain properties (Thompson et al., 2009), which is beneficial for consumers, however, can make positive identification of polymer particles challenging given the numerous combinations of possible ingredients. 
The majority of plastic waste comes from single-use packaging, and ever since the recent global shift from using reusable containers to single-use containers, single-use packaging has greatly increased (Geyer et al., 2017). Geyer et al. (2017) estimated that around $4900 \mathrm{Mt}$ of all plastic ever produced have been discarded and are either accumulating in landfills or in the environment. Globally, waste is regularly being released into the environment through littering, large-scale dumping, and poorly managed waste collection and landfill sites (Duis and Coors, 2016). Furthermore, for a long time, oceans, lakes, and rivers have been convenient locations for waste disposal, and according to GESAMP (2015), since plastics are inherently persistent, they are considered to be the most problematic out of all anthropogenic material being disposed of in these waters. Plastic pollution and plastic debris in the aquatic environment first became a concern following reports of harm being caused to marine animals from floating macroplastics (plastics larger than $5 \mathrm{~mm}$ ), including entanglement and suffocation from ingestion (Browne et al., 2007; Derraik, 2002; GESAMP, 2015).

\subsection{Microplastic Pollution}

Microplastics, which are defined as plastic particles smaller than five millimeters (Arthur and Baker, 2011), are an emerging anthropogenic contaminant polluting aquatic and terrestrial ecosystems worldwide. Plastics do not biodegrade but many plastics can breakup into smaller particles that can be transported throughout the environment (Barnes et al., 2009). These particles can enter the environment through various different sources and are of particular concern as they can be ingested by many organisms, causing a range of harmful effects (Browne et al., 2007). Floating microplastics in oceanic waters were first reported in the early 1970s (Carpenter et al., 1972; Carpenter and Smith, 1972), however, this pollutant has only recently

received increased international attention as a contaminant of concern (Browne et al., 2007). 
Microplastic particles range greatly in both shape and colour, and particles can be classified into categories that can further assist with identifying the source of the particle (Helm, 2017; Rochman et al., 2019). There is some variation in the amount of particle shape categories that are reported in studies, however, common categories include fibre, fibre bundle, film, foam, fragment, pellet (also referred to as nurdle), and sphere (also referred to as bead/microbead; Rochman et al., 2019). Microplastics are also classified by their general origin and are grouped into either primary or secondary microplastics. Primary microplastics are those which have been manufactured at a size smaller than $5 \mathrm{~mm}$ (Cole et al., 2011; De Witte et al., 2014) and are created either as raw material for the fabrication of user plastics (i.e. pellets/nurdles; Duis and Coors, 2016), or for various applications such as scrubbers in personal care products (i.e. spheres/microbeads; Fendall and Sewell, 2009; Leslie, 2014), or as abrasives in industrial applications (i.e. plastic media airblasting; Gregory, 1996). Secondary microplastics are plastic particles which have fragmented off of other plastic material, typically as a result of physical and/or chemical weathering of plastics already present in the environment, or from the regular use of plastic material (Andrady, 2003; Browne et al., 2007; Cole et al., 2011; Talvitie et al., 2017).

When referring to plastic debris in the environment, it is increasingly common for studies to refer to plastics as being either of industrial or user origin (Poon et al., 2017; Provencher et al., 2017; Provencher et al., 2015; van Franeker and Law, 2015). Industrial plastics, which are also classified as primary plastics, are the raw plastics also known as nurdles or pre-production pellets used to manufacture user plastics, while user plastics include any items that are used as commercial goods (Karlsson et al., 2018; Van Franeker and Law, 2015). The difference between 
secondary microplastics and user plastics is that the latter do not necessarily have to be microplastics as they can encompass all user plastic debris, whether it be micro- or macroplastic.

\subsection{Sources, Drivers, and Distribution of Plastic and Microplastic Pollution in the Environment}

\subsubsection{Water}

The presence and persistence of plastic and microplastic pollution in the environment is becoming increasingly appreciated, however, understanding their distribution within different environmental systems is still a topic that needs to be investigated further. One way that plastic and microplastic debris is known to circulate through environmental systems is by water. Microplastics can enter the aquatic environment through several routes, yet studies are increasingly recognizing that wastewater effluent is an important conduit for microplastic pollution in aquatic environments (Duis and Coors, 2016; Leslie et al., 2017; Mason et al., 2016; Talvitie et al., 2015; Vermaire et al., 2017; Ziajahromi et al., 2017). Conventional wastewater treatment has been found to be effective at removing most microplastics (Gies et al., 2018; Murphy et al., 2016), however, large quantities of microplastics can still be discharged into receiving waters given the large volume of wastewater effluent (Mason et al., 2016; Murphy et al., 2016; Talvitie et al., 2017). The plastic pollution in these waters predominantly includes primary microplastics from personal care products and microplastic fibres released from textiles during laundering (Almroth et al., 2018; Duis and Coors, 2016; Salvador Cesa et al., 2017; Vassilenko et al., 2019). In addition to the input of microplastics to the environment from wastewater effluent, many microplastics can settle into sludge during treatment, which is then often applied to land in the form of biosolids for agrosystems and industrial site reclamations (Habib et al., 1998; Leslie et al., 2017; Mahon et al., 2017; Zubris and Richards, 2005). These biosolids that are applied to land can represent another important route for microplastic 
contamination, as they can be washed into aquatic systems during rainfall and runoff events (Habib et al., 1998; Leslie et al., 2017; Mahon et al., 2017; Zubris and Richards, 2005). Since the majority of research investigating the input of microplastic pollution via wastewater treatment has focused on regions with larger population densities, the concentrations provided by these studies may be less representative for more remote areas with smaller populations, such as the Arctic.

Studies have identified oceans as sinks for plastic and microplastic pollution (Eriksen et al., 2014; Horton and Dixon, 2017) with freshwater and terrestrial environments acting as important routes for this pollution (Jambeck et al., 2015; Lechner et al., 2014). A large part of the plastic debris in marine environments has converged and accumulated in ocean gyres (Eriksen et al., 2014; van Sebille et al., 2015), however, there is increasing recognition that some marine plastic pollution is moving towards the Arctic and Antarctic regions (Lusher et al., 2015b; Moore et al., 2001; Ryan et al., 2009; Thompson et al., 2009). A recent study has even suggested that the Arctic Ocean may act as an accumulation point for plastic pollution (Cózar et al., 2017). These studies indicate that inputs from urban areas further south, such as wastewater effluent, could still represent a source for Arctic plastic pollution. The movement of plastic pollution in water means that this pollutant can easily be transported to regions where there may be fewer local inputs, and which have previously been considered as "untouched" or "pristine" (Bergmann et al., 2019; Halsband and Herzke, 2019; Kühn et al., 2018). Furthermore, even if inputs of plastics into the World's oceans decreases, plastic pollution in the Arctic is expected to continue increasing (Cózar et al., 2017). The movement and spread of plastic pollution via water increases the likelihood of aquatic animals encountering it, which may increase the opportunities for entanglement and/or ingestion. 
Recently, Huntington et al. (2020) found between 0 and 0.61 anthropogenic particles per litre from grab samples of surface waters in Hudson Bay, Canada and around the Canadian Arctic Archipelago. Near the coast of Svalbard, Norway, Lusher et al. (2015) found concentrations between 0 and 1.31 microplastic particles per $\mathrm{m}^{3}$ in surface water samples collected with a manta trawl, and between 0 and 11.5 microplastic particles per $\mathrm{m}^{3}$ in subsurface water samples collected at a depth of 6 metres using a pump. Similarly, Morgana et al. (2018) sampled Arctic waters off northeast Greenland at 6 metres below the surface and reported between 1 and 3 microplastic fragments per $\mathrm{m}^{3}$, however, did not include estimates for microfibres due to concerns about contamination. Many plastics are buoyant and will therefore float near the surface of the water, however, certain plastics with a greater density will tend to sink to the benthic zone (Andrady, 2011; GESAMP, 2015). Buoyant microplastic particles can also sink as a result of biofilm aggregation and biofouling (Lobelle and Cunliffe, 2011). As such, plastic and microplastic pollution has been found in deep-sea sediments (Bergmann et al., 2017; Tekman et al., 2017; Van Cauwenberghe et al., 2013). Tekman et al. (2017) found through photographic time-series surveys that marine debris on the deep Arctic seafloor has increased greatly between 2002 and 2014, and Bergmann et al. (2017) found concentrations of microplastic pollution between 42 and 6595 microplastic particles per $\mathrm{kg}$ of deep sea sediments collected from the HAUSGARTEN observatory in Norway.

\subsubsection{Atmospheric Deposition}

Although specific to microplastic pollution, and even more commonly for microfibres, an emerging means of microplastic distribution throughout the environment gaining increasing attention is that of atmospheric deposition. Atmospheric deposition of microplastics has been reported in various studies around the world and has focused on both urban environments (e.g. 
Cai et al., 2017; Dehghani et al., 2017; Dris et al., 2016, 2015) and remote environments (e.g. Allen et al., 2019; Free et al., 2014). Although the most dominant particle type transported by the atmosphere is microfibre, some research suggests other particle types such as fragments, films, and foams may also be transported through atmospheric deposition (Cai et al., 2017; Kole et al., 2017). Another recent study suggests that although synthetic microfibres have been found in atmospheric samples, many microfibres being transported in the atmosphere are likely from natural textiles such as cotton or wool (Stanton et al., 2019).

Atmospheric deposition is likely another way that microplastics are being inputted to the Arctic. Various contaminants such as organic compounds and metals have been documented in the Arctic as a result of long-range transport (Barrie et al., 1992; Cotham and Bidleman, 1991; Macdonald and Bewers, 1996; Zhang et al., 2013), therefore, it is expected that microplastics are also being transported to the Arctic in a similar way. Recently, studies have identified microplastics in Arctic snow indicating the transport of microplastic pollution to the Arctic through the atmosphere (Bergmann et al., 2019; Huntington et al., 2020). Microplastics have also been recently reported in Arctic sea ice, and ice has been suggested as a potential sink for this contaminant in the Arctic (Obbard et al., 2014; Peeken et al., 2018). The accumulation of microplastics in Arctic sea ice can be attributed to an uptake from microplastics in the surrounding surface waters (Obbard et al., 2014; Peeken et al., 2018), as well as microplastics being deposited on top of ice via atmospheric deposition (Bergmann et al., 2019).

\subsubsection{Animal Transport}

Another way that microplastics might move around the environment is through animal transport. Recent studies have shown that some animals are excreting microplastic particles in their faeces, including birds (Gil-Delgado et al., 2017; Provencher et al., 2018) and seals 
(Donohue et al., 2019; Eriksson and Burton, 2003; McMahon et al., 1999; Nelms et al., 2018). Although microplastic particles have been found in freshwater bird (e.g. Gil-Delgado et al., 2017) and seal scats (e.g. Donohue et al., 2019), the counts of microplastics are typically low and these animals do not usually remain in largely populated groups. As such, these animals may not be a notable source of microplastic pollution in the environment. Arctic seabirds, conversely, could be a particularly important source of microplastic pollution in the Arctic given that they are colonial breeders and congregate annually in very large populations.

It has been well documented that northern seabirds can act as biovectors moving contaminants from marine systems into terrestrial Arctic environments (Blais et al., 2005; Choy et al., 2010; Michelutti et al., 2009), however, the role of animals as vectors for microplastic pollution has yet to be fully examined. A recent study was conducted on the presence of microplastics in seabird guano (Provencher et al., 2018), which showed a positive (although nonsignificant) correlation between plastics found in the stomachs of birds and microplastic particles in the bird guano. However, environmental samples in areas with high concentrations of seabird guano have not yet been looked at to see whether the microplastics being excreted via guano are being accumulated in the environment. Nonetheless, since seabirds have the ability to excrete large quantities of guano, the presence of bird colonies could be a driver of microplastics in nearby water and sediment. The process of excretion of microplastics in seabird guano is discussed further in section 2.4.2.

\subsection{Consequences of Plastic Pollution}

\subsubsection{Entanglement}

Plastic debris has been found to cause many deleterious effects on nearly all exposed animals, primarily through entanglement and ingestion (Derraik, 2002; Gall and Thompson, 
2015; Kühn et al., 2015; Laist, 1997). Entanglement is typically a consequence of macroplastic debris and is often linked to debris such as derelict fishing gear, as well as most other anthropogenic material that ends up in the environment (Kühn et al., 2015). Entanglement can cause a range of harm, including drowning, starvation as a result of not being able to acquire food, and physical wounds (Kühn et al., 2015; Laist, 1997).

One of the earliest reports of plastic entanglement in the literature dates back to 1931 when a shark was found trapped in a rubber automobile tire (Gudger and Hoffmann, 1931). Since then, hundreds of species have been reported to suffer from entanglement in anthropogenic debris (Kühn et al., 2015; Laist, 1997), and as concentrations of plastic pollution continue to increase, the encounters animals have with anthropogenic debris have become more frequent over time (Gall and Thompson, 2015). Furthermore, an increasing number of studies examining the effects of plastic pollution in the environment are revealing that the amount of different species suffering from entanglement and/or ingestion of plastics is also increasing (Gall and Thompson, 2015; Provencher et al., 2017).

\subsubsection{Ingestion}

The majority of studies on plastic ingestion have focused on marine birds (Provencher et al., 2017), however, other animals that have been reported to ingest plastic and microplastic pollution include mammals (e.g. de Stephanis et al., 2013; Denuncio et al., 2017), fishes (e.g. Foekema et al., 2013; Rummel et al., 2016), reptiles (e.g. Schuyler et al., 2012), and invertebrates (e.g. Cole et al., 2013; Li et al., 2019). The ingestion of plastic pollution can have many harmful effects including the obstruction of and physical damage to the digestive tract (Carey, 2011; Kühn et al., 2015; Pettit et al., 1981), appetite suppression and a false sense of satiation from accumulated plastics (Kühn et al., 2015; Ryan, 1988), poor nutrition or starvation 
as a result of plastics obstructing the passage of food (Auman et al., 1997; Dickerman and Goelet, 1987; Pierce et al., 2004), and reduced growth rates (Sievert and Sileo, 1993). Though many negative effects of plastic ingestion have been reported, it is possible that microplastics also simply move through the systems of larger animals and are excreted out, without causing harm to the organism, however, this needs further investigation.

Fewer studies exist for plastic ingestion by animals in the Arctic, however, with the growing recognition that plastic pollution in the Arctic is likely to increase (Cózar et al., 2017), assessing the interaction Arctic animals have with plastic pollution is becoming an important area of inquiry. Studies investigating the effects of and ingestion frequencies of plastic pollution by animals in the Arctic have been largely dominated by seabird studies (Provencher et al., 2017), however, other Arctic animals have been examined such as fishes (Bråte et al., 2016; Kühn et al., 2018; Morgana et al., 2018; Nielsen et al., 2014), whales (Moore et al., 2020) and seals (Donohue et al., 2019).

\subsubsection{Ingestion of Plastic Pollution by Marine Mammals}

Although some studies exist, there have been far fewer reports of plastic ingestion by marine mammals than seabirds, and this is especially true for marine mammals in the Arctic. Nevertheless, the ingestion of plastic pollution has been documented around the world for some marine mammals including pinnipeds (Bravo Rebolledo et al., 2013; Denuncio et al., 2017; Donohue et al., 2019; McMahon et al., 1999; Nelms et al., 2019, 2018; Unger et al., 2017), cetaceans (Lusher et al., 2018; Nelms et al., 2019; Panti et al., 2019; van Franeker et al., 2018), and sirenians (Attademo et al., 2015; Beck and Barros, 1991). Most studies for ingested plastic pollution in marine mammals tend to focus on macro- and/or microplastics in the gastrointestinal tracts (GITs; either entire GIT or occasionally only a section; e.g. Denuncio et al., 2017; Nelms 
et al., 2019; Unger et al., 2017), however, some look at egested microplastics in scat samples (e.g. Donohue et al., 2019; Eriksson and Burton, 2003; Nelms et al., 2018), or a combination of GIT and scat (e.g. Bravo Rebolledo et al., 2013; Moore et al., 2020). Cetaceans appear to be most commonly reported on for ingested plastic pollution, and few studies currently exist for any Arctic marine mammal (e.g. Donohue et al., 2019; Moore et al., 2020), yet none of which are based in the eastern Canadian Arctic. Except for some cases, many of the results from studies reporting on the ingestion of plastic pollution and anthropogenic debris show generally low frequencies of occurrence of plastic pollution in the animals. The occurrence of ingested plastic pollution in some species, such as filter-feeders, could be the result of indiscriminate feeding (Besseling et al., 2015; Nelms et al., 2018). The ingestion of macroplastics appears to be less common for pinnipeds, suggesting that these animals could be less likely to encounter larger plastic debris during feeding. A summary of a selection of studies that have reported macroand/or microplastic pollution in the GITs of marine mammals is provided in Table 7.1.

In 2015, Donohue et al. (2019) conducted a study to investigate northern fur seal (Callorhinus ursinus) scat from two islands in Alaska, U.S.A. and one island in California, U.S.A. for microplastic pollution. They found 437 microplastic particles in the 35 seal scats collected from two islands in Alaska, and 32 microplastic particles in 7 seal scats collected from California (Donohue et al., 2019). Similar to prior studies that have looked for microplastic pollution in seal scats (e.g. Bravo Rebolledo et al., 2013; Eriksson and Burton, 2003; McMahon et al., 1999; Nelms et al., 2018; Perez-Venegas et al., 2018), Donohue et al. (2019) demonstrates the exposure of these seals to microplastic pollution, and suggests the use of faecal collection as a potential non-invasive way of monitoring microplastic pollution exposure in some marine mammals. However, a potential challenge with this method is that it may not always be possible 
to discern between plastic particles in the scat with those originating from atmospheric deposition (Dris et al., 2016).

Another recent study looked for microplastic pollution in the GITs of seven beluga whales (Delphinapterus leucas) from Tuktoyaktuk, Northwest Territories, Canada (Moore et al., 2020). They found a total of 350 suspected microplastic particles, and identified particles in each sampled whale (Moore et al., 2020). The results from this study further validate the idea that microplastics within these large mammals are likely transitory, and are entering and exiting the animals as they move throughout the environment (Lusher et al., 2018; Moore et al., 2020; Nelms et al., 2019). Microplastic particles found in seal scat are likely to be from secondary ingestion of microplastics, whereby seals ingest prey items that already contained microplastic particles (Donohue et al., 2019; Eriksson and Burton, 2003; Nelms et al., 2018). This situation was suggested in McMahon et al. (1999) when the authors found microplastic fragments in scats collected from Hooker's sea lions (Phocarctos hookeri) concurrently with otoliths from lanternfish (Electrona subaspera). In the Arctic, fishes such as the polar cod (Boreogadus saida) and the Atlantic cod (Gadus morhua), which are important prey for many Arctic marine mammals, have been found to contain microplastic pollution (Bråte et al., 2016; Kühn et al., 2018; Morgana et al., 2018), suggesting a potential source of microplastic pollution in Arctic marine mammals.

Generally, marine mammals can be difficult to study for ingested plastics for a few reasons. Firstly, the size of the GITs is substantial, which makes laboratory processing challenging, especially when looking for microplastic particles where stomach contents need to be chemically digested. Further, many studies that have assessed plastic pollution ingestion by marine mammals have had to rely on opportunistic sampling where the mammals are either 
found stranded ashore or found dead as a result of fishery bycatch, which means that a large sample size is not often possible (Lusher et al., 2018). However, monitoring certain marine mammals in the Arctic may be possible given the regular harvest of certain species for subsistence. Arctic seal stomachs, for example, may be readily available and could provide an opportunity for plastic monitoring in a marine mammal, similar to current monitoring using northern fulmars (Fulmarus glacialis). That said, many of the studies that have looked at marine mammal GITs have reported generally low occurrences of macro- and/or microplastics (see Table 7.1). This, again, could likely be attributed to feeding strategies, where many marine mammals, and particularly pinnipeds, tend to pursue their prey within the middle of the water column as opposed to foraging on the surface of the water.

\subsubsection{Ingestion of Plastic Pollution by Seabirds}

The ingestion of debris by a seabird was first reported in 1838 when part of a candle stick was found in the gut of a Wilson's storm petrel (Oceanites oceanicus; Provencher et al., 2017 citing Couch 1838), and seabirds in Canada have been reported to ingest plastic pollution since the early 1960s (Rothstein, 1973; Threlfall, 1968). Since these times, many other species of seabirds as well as the quantity and frequency of reports on seabird ingestion of plastic pollution have increased exponentially (Provencher et al., 2017). Some species of seabirds are more likely to ingest plastics than others because of their feeding strategies. For example, birds that feed on the surface where many plastics are known to float, such as Procellariiformes (e.g. albatrosses, Diomedeidae spp.; petrels, Procellariidae spp.; shearwaters, Ardenna spp.; and storm-petrels, Hydrobatidae spp. and Oceanitidae spp.), have been found to ingest and accumulate more plastic pollution than birds that feed below the surface (Azzarello and Van Vleet, 1987; Moser and Lee, 1992; Poon et al., 2017; Robards et al., 1995). However, pursuit/diving feeders have still been 
reported having plastic debris in the GITs (e.g. Bond et al., 2013; Tavares et al., 2017). Some species of seabirds have also been found to feed plastics to their chicks. This has been most commonly seen in albatrosses (Auman et al., 1997; Fry et al., 1987; Rapp et al., 2017; Sievert and Sileo, 1993) and shearwaters (Carey, 2011; Cousin et al., 2015; Fry et al., 1987; Lavers et al., 2014; Verlis et al., 2018, 2013), but has also been reported in Bonin petrels (Pterodroma hypoleuca), Cory's shearwaters (Calonectris diomedea), masked boobies (Sula dactylatra), redtailed tropicbirds (Phaethon rubricauda), Tristram's storm-petrels (Oceanodroma tristrami), and Wilson's storm-petrels (Oceanites oceanicus; e.g. Rapp et al., 2017; Rodríguez et al., 2012; van Franeker and Bell, 1988). Chick regurgitates from black-legged kittiwakes (Rissa tridactyla), northern fulmars and great cormorants (Phalacrocorax carbo) from breeding colonies in Ireland have also been found to contain plastic pollution (Acampora et al., 2017). The ingestion of plastics by chicks in the Arctic, however, has been understudied.

Colonial seabirds, such as northern fulmars and thick-billed murres (Uria lomvia), are relatively easy to study for plastic ingestion compared to other animals since they can typically be easy to access when breeding in large quantities on land (Provencher et al., 2017). As such, these seabirds have been largely used as biomonitors for regional plastic pollution, especially in the Arctic (Provencher et al., 2017). Since seabirds can forage over large areas, studying the plastics they ingest provides an insight to the extent of plastic pollution in the surrounding region (Avery-Gomm et al., 2018; Provencher et al., 2015). Further, fulmarine petrels are more likely to retain plastic pollution in their guts compared to other species of seabirds because they have a limited ability to regurgitate debris (van Franeker and Law, 2015), which may make ingestion by these seabirds easier to monitor. Indigestible hard items are rarely regurgitated since these birds tend to only expel ingested material when feeding their chicks or in response to acute stress (van 
Franeker and Law, 2015). The material that is expelled during these situations is only what is present in the cranial proventriculus because any material that has made its way to the gizzard is trapped by the narrow passage between the proventriculus and the gizzard (Ryan and Jackson, 1986). Typically, hard food items and debris (e.g. plastics) accumulate in the muscular gizzard where they are ground up until they are fragmented into small enough pieces to pass into the intestines and be excreted through the cloaca (Figure 2.1; Provencher et al., 2018; Reynolds and Ryan, 2018; van Franeker and Law, 2015). That said, although microplastics that are excreted via guano could have originated from larger plastic pollution that has been mechanically ground up by the gizzard, a portion of microplastics in guano may be so small that they would not have been retained in the GIT, and would have simply passed through the GIT unobstructed (Provencher et al., 2018).

A recent study examined the faecal precursors (last approximately $10 \mathrm{~cm}$ of the gastrointestinal tract including a section of the small intestine and the cloaca) of 30 northern fulmars collected from the Labrador Sea in 2015 (Provencher et al., 2018). This study aimed to first identify if there were any microplastics in the bird guano, and then to also assess whether a relationship existed between microplastic particles in faecal precursor samples and plastic debris found in the same bird stomachs that had been previously reported by Avery-Gomm et al. (2018). Provencher et al. (2018) found that $97 \%$ of the bird GITs contained plastic pollution, while $47 \%$ had microplastics in the faecal precursor samples. These results suggest that seabirds may be acting as a vector for transporting microplastics from the marine environment to the terrestrial environment (Provencher et al., 2018). Furthermore, since seabirds are often colonial breeders and tend to congregate in large groups during the breeding period (Gaston et al., 2012), 
their guano could represent a significant source of microplastic pollution in the environment, and especially in the Arctic where there are fewer direct inputs.

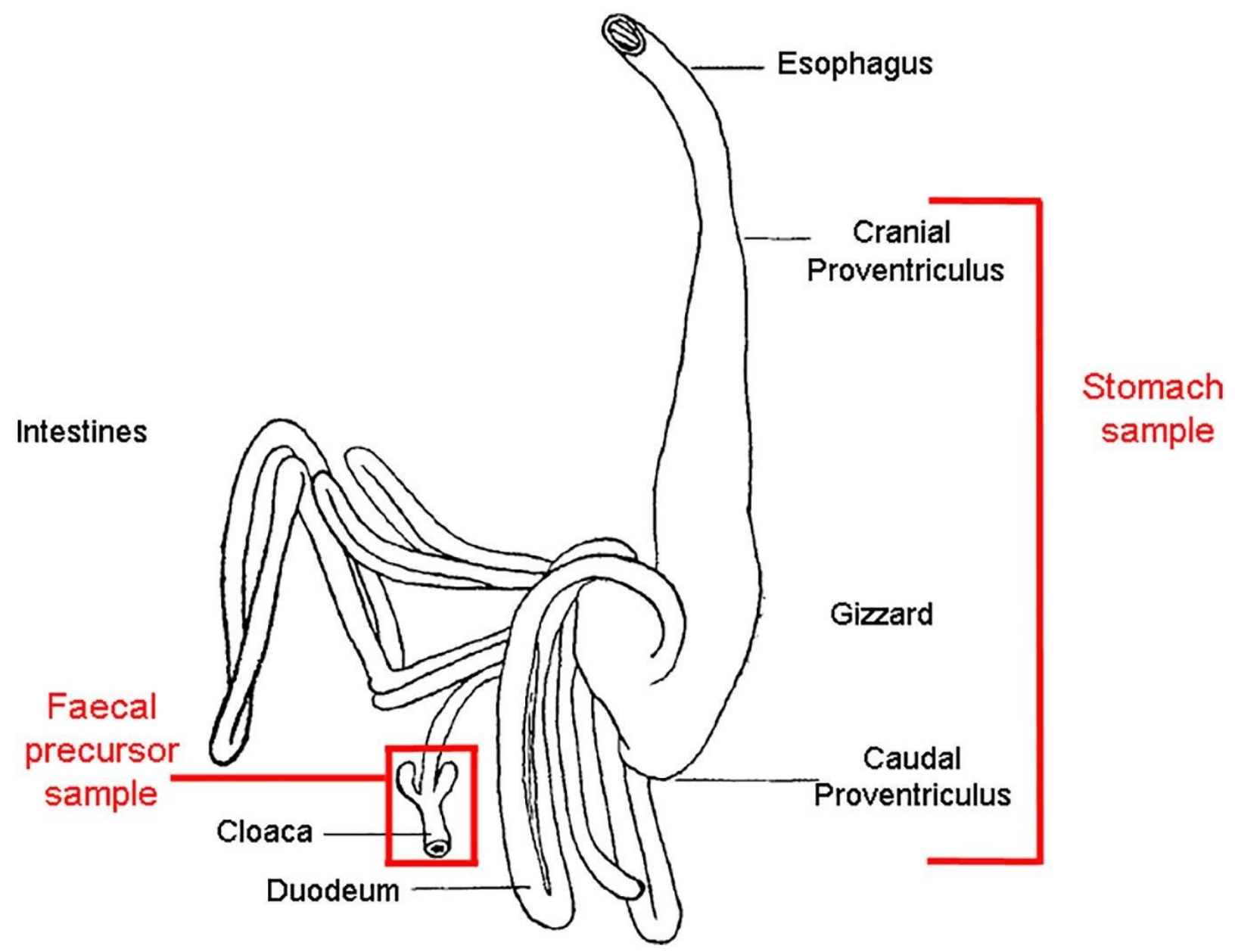

Figure 2.1: The gastrointestinal tract of a northern fulmar (Fulmarus glacialis). Hard, ingested material, including plastics, typically accumulate in the muscular gizzard where they are mechanically ground up until they are small enough to move through the intestines and be excreted via the cloaca. Bird stomachs, including the proventiculus and the gizzard are typically dissected in plastic ingestion studies, however, the faecal precursor samples (cloaca and a section of the small intestine) are useful to assess concentrations of excreted microplastics. Figure taken from Provencher et al. (2018) and reprinted with permission from Elsevier. 


\subsubsection{Chemical \& Toxin Transfer}

Another potential consequence of plastic ingestion that more studies are now looking into is the way in which microplastics may act as a pathway for contaminants and toxins to enter an organism's body (Andrady, 2011). Studies have found that chemicals associated with plastic pollution (e.g. additives such as polybrominated diphenyl ethers (PBDEs), substituted diphenylamine antioxidants (SDPAs) and benzotriazole UV stabilizers (BZT-UVs)), as well as those that have adsorbed onto plastics while in the environment (e.g. trace elements and persistent organic pollutants) can be passed to the organisms that have ingested the plastics (Browne et al., 2007; Lavers et al., 2014; Lu et al., 2019; Tanaka et al., 2013; Teuten et al., 2009). These chemicals can have harmful effects such as disruption to the endocrine system (Liang et al., 2017; Teuten et al., 2009). The toxins that are ingested by organisms at lower trophic levels can further biomagnify in predators, which may enhance the chemical consequences of these toxins (Teuten et al., 2009). Further to the transfer of toxins within or adsorbed to microplastic particles, very small microplastic particles may even be able to translocate within an organism at a cellular level, however, the effects of this are still largely unknown (Browne et al., 2008).

\subsection{Methods Used to Research Plastic Pollution in Animals}

Since plastic pollution and microplastics research is a relatively new area of research, there remains a lack of harmonization and standardization of methodologies for sample collection, analysis, and reporting. Scientists for several years have been urging for the harmonization and standardization of methods (Eriksen et al., 2014; Filella, 2015; Koelmans et al., 2019; Löder and Gerdts, 2015; Provencher et al., 2017; Rocha-Santos and Duarte, 2015; Rochman et al., 2017; Ryan et al., 2009; Salvador Cesa et al., 2017; Twiss, 2016; Van 
Cauwenberghe et al., 2015), particularly because without harmonization and/or standardization, the comparison of data between studies is challenging if not impossible. There is greater variation in methods for environmental samples looking at microplastic pollution (i.e. water and sediment studies), however, variation also exists in studies assessing plastic pollution in animals.

\subsubsection{Laboratory Methods}

Methods for processing samples in the laboratory will vary depending on the size range being examined. Nested sieves are commonly used to separate size classes of plastic debris as well as to pick out debris items from other stomach contents (Provencher et al., 2017). One challenge with quantifying microplastic particles in biota, especially fibres and small particles that may be easily overlooked, is that the particles are often hidden by organic material, making them difficult to isolate. To facilitate with isolating particles, organic material can be digested using various chemicals before sieving/filtering the samples and inspecting for microplastic particles (Lusher et al., 2017). Certain chemicals that have been used to digest organic material, notably strong oxidizing agents, have also been shown to degrade synthetic polymers, especially when high temperatures are used to facilitate digestion (Lusher et al., 2017). As such, recent studies are suggesting that potassium hydroxide $(\mathrm{KOH})$ should be the predominant chemical used for digestion (Hurley et al., 2018; Kühn et al., 2017; Lusher et al., 2017; Miller et al., 2017). Overall, the type of chemicals used to digest organic material, as well as the filtering techniques and ways particles are picked can vary among studies (Lusher et al., 2017).

Another important consideration for microplastics research is the risk of contamination. As some studies have shown, atmospheric deposition of microfibres can occur in remote locations (e.g. Free et al., 2014; Obbard, 2018), highlighting the need to collect field controls during sample collection to account for any potential contamination. Further, the potential for 
indoor contamination is particularly important to consider when processing samples, as microfibres can be shed from clothing, laboratory coats, or be present in dust (Dris et al., 2017). As such, collecting laboratory controls or blanks is important to ensure potential contamination is considered in the results and can be subtracted from the sample counts.

\subsubsection{Polymer Identification Techniques}

The first step in particle classification and identification is usually done through visual classification of the particles using stereo-microscopy, which is then followed by chemically identifying a subset of the particles from the sample (Crawford and Quinn, 2017; Lusher et al., 2017). During microscopy, particles are classified by their morphological characteristics, including shape (e.g. fibre, film, foam, fragment, pellet, sphere), colour, and size (Lusher et al., 2017). Many studies use a broad spectrum of colours for grouping particles (e.g. a Munsell colour chart; Provencher et al., 2017), however, colour differentiation can be largely subjective and thus colour cannot be used as the only method of identification or categorization (Lusher et al., 2017).

Chemically identifying and characterizing particles is becoming an increasingly crucial step in order to ensure particles are in fact plastic or of anthropogenic origin, and to avoid overestimating counts of anthropogenic particles (Lenz et al., 2015; Munno et al., 2020). This is particularly relevant as more studies are now reporting on very small particles that are impossible to positively confirm visually (Lenz et al., 2015; Munno et al., 2020). Particle identification and characterization is most commonly done through Fourier-transform infrared spectroscopy (FTIR; e.g. Besseling et al., 2015; Bråte et al., 2016; Covernton et al., 2019; Foekema et al., 2013) and Raman spectroscopy (e.g. Cole et al., 2014; Van Cauwenberghe and Janssen, 2014). Using Scanning Electron Microscopes (SEM; e.g. Eriksson and Burton, 2003) and Nile red dye (e.g. 
Catarino et al., 2018) have also been published as methods of identifying polymers, however, these methods seem to be less commonly employed in studies assessing microplastics ingested by animals. Recently, spectral libraries have been developed specifically for identifying microplastic particles and various additives commonly used in the production of plastics (Munno et al., 2020; Primpke et al., 2018), which greatly improves the ability and accessibility of positively identifying particles. 


\section{No Plastics Detected in Seal (Phocidae) Stomachs Harvested in the Eastern Canadian Arctic}

Madelaine P.T. Bourdages ${ }^{1}$, Jennifer F. Provencher ${ }^{2}$, Enooyaq Sudlovenick ${ }^{3}$, Steven H.

Ferguson ${ }^{4}$, Brent G. Young ${ }^{4}$, Nicolas Pelletier ${ }^{1}$, Michael J.J. Murphy ${ }^{1}$, Alexa D’Addario ${ }^{1}$, Jesse C. Vermaire ${ }^{1,5}$

${ }^{1}$ Carleton University, Geography and Environmental Studies, 1125 Colonel By Drive, Ottawa, ON K1S 5B6, Canada

${ }^{2}$ Environment and Climate Change Canada, 200 Boulevard Sacré-Coeur, Gatineau, QC J8X 4C6, Canada

${ }^{3}$ University of Prince Edward Island. Current address: University of Manitoba, 66 Chancellors Cir, Winnipeg, MB R3T 2N2, Canada

${ }^{4}$ Fisheries and Oceans Canada, 501 University Crescent, Winnipeg, MB R3T 2N6, Canada

${ }^{5}$ Carleton University, Institute for Environmental and Interdisciplinary Sciences, 1125 Colonel By Drive, Ottawa, ON K1S 5B6, Canada

This paper has been published in Marine Pollution Bulletin (Bourdages et al., 2020). 


\subsection{Introduction}

Plastic pollution has been found in virtually all oceanic and coastal regions (Kühn et al., 2015) and there is increasing recognition that some marine plastic pollution is moving as far as the Arctic and Antarctic regions (Thompson et al., 2009). It has even been suggested that portions of the Arctic Ocean act as a final accumulation point for plastic movement in the World's Oceans (Cózar et al., 2017). Therefore, it is critical that we gain a better understanding of the prevalence and concentration of plastic pollution in the Arctic and how this plastic debris may be impacting Arctic wildlife.

Few studies of plastic ingestion and retention rates in stomachs exist for marine mammals and this is particularly true for Arctic marine mammals. Seals (Phocidae) are an important component of marine Arctic ecosystems and also make up an important portion of the diets of Inuit, holding high cultural, social and economic value for many northern communities (Searles, 2019). In regions where subsistence hunting accounts for an important nutrient source, it is critical to examine plastic ingestion and accumulation in species that may result in negative effects on wildlife or its consumers.

In this study, we examined the stomach contents of 142 seals (ringed seals [Phoca hispida; $n=135$ ], bearded seals [Erignathus barbatus ; $n=6$ ], and a single harbour seal [Phoca vitulina $; n=1])$ to investigate if seals from the eastern Canadian Arctic are ingesting and retaining plastics. Given that some avian species in the region have been found to ingest and accumulate plastic debris (e.g. Provencher et al., 2010), and that contaminants potentially derived from plastics were found in Arctic seal tissues (Lu et al., 2019), we predicted that we would find plastic debris in the seal stomachs. These data are important as they provide the first 
assessment of plastic pollution in an ecologically and culturally important marine mammal in the eastern Canadian Arctic.

\subsection{Methods}

Stomachs were collected from 142 seals harvested by Inuit hunters for subsistence in 2007, 2008, 2018 and 2019 from Arviat $\left(61.1078^{\circ} \mathrm{N}, 94.0624^{\circ} \mathrm{W}\right)$, Naujaat $\left(66.5283^{\circ} \mathrm{N}\right.$, $\left.86.2447^{\circ} \mathrm{W}\right)$, Sanikiluaq $\left(56.5408^{\circ} \mathrm{N}, 79.2232^{\circ} \mathrm{W}\right)$, and Iqaluit $\left(63.7467^{\circ} \mathrm{N}, 68.5170^{\circ} \mathrm{W}\right)$, Nunavut, Canada (Figure 3.1). Tissues from the seals were harvested with permits from the Department of Fisheries and Oceans (DFO; DFO LFSP S-17/18 1005-NU), approval from the Nunavut Wildlife Management Board (NWMB), and support from the Arviat, Arviq, Sanikiluaq, and Amaruq Hunter and Trapper Organizations. The species, sex, and body measurements of the seals were recorded by the hunters. The relative age of some seals were determined by the hunters, while for other seals the lower right canine teeth were sent to Matson's Laboratory (Montana, U.S.A.) to determine age via counting cementum annuli from a cross-sectioned portion of the tooth (Stewart et al., 1996). The seal stomachs were removed by the hunters, placed into low-density polyethylene bags and frozen to be analysed at a later date. Other tissues were taken by the hunters for studies involving the health of the seals, including pathology and contaminants.

In April 2019, the seal stomachs were shipped frozen to Carleton University (Ottawa, Canada) to be dissected and inspected for accumulated plastics. In the laboratory the seal stomachs were thawed and weighed. The stomachs were then cut open with a pair of clean scissors and the stomach contents were visually inspected. The dominant diet items were noted, but not quantified. The stomach contents were then removed, weighed, and sieved through nested stainless-steel sieves (mesh size $850 \mu \mathrm{m}$ and $425 \mu \mathrm{m}$ ) and rinsed using tap water. Material 
retained by the $850 \mu \mathrm{m}$ sieves were visually inspected for any plastics. Visual inspection involved thoroughly picking through sections of the stomach contents using forceps and running tap water. Any material that was hard, floated, was sheet like, or was of bright colour was placed into a Petri dish to be inspected more closely under a microscope. The material retained by the $425 \mu \mathrm{m}$ sieves were rinsed into Petri dishes and carefully inspected under a Leica stereomicroscope at 50 times magnification.

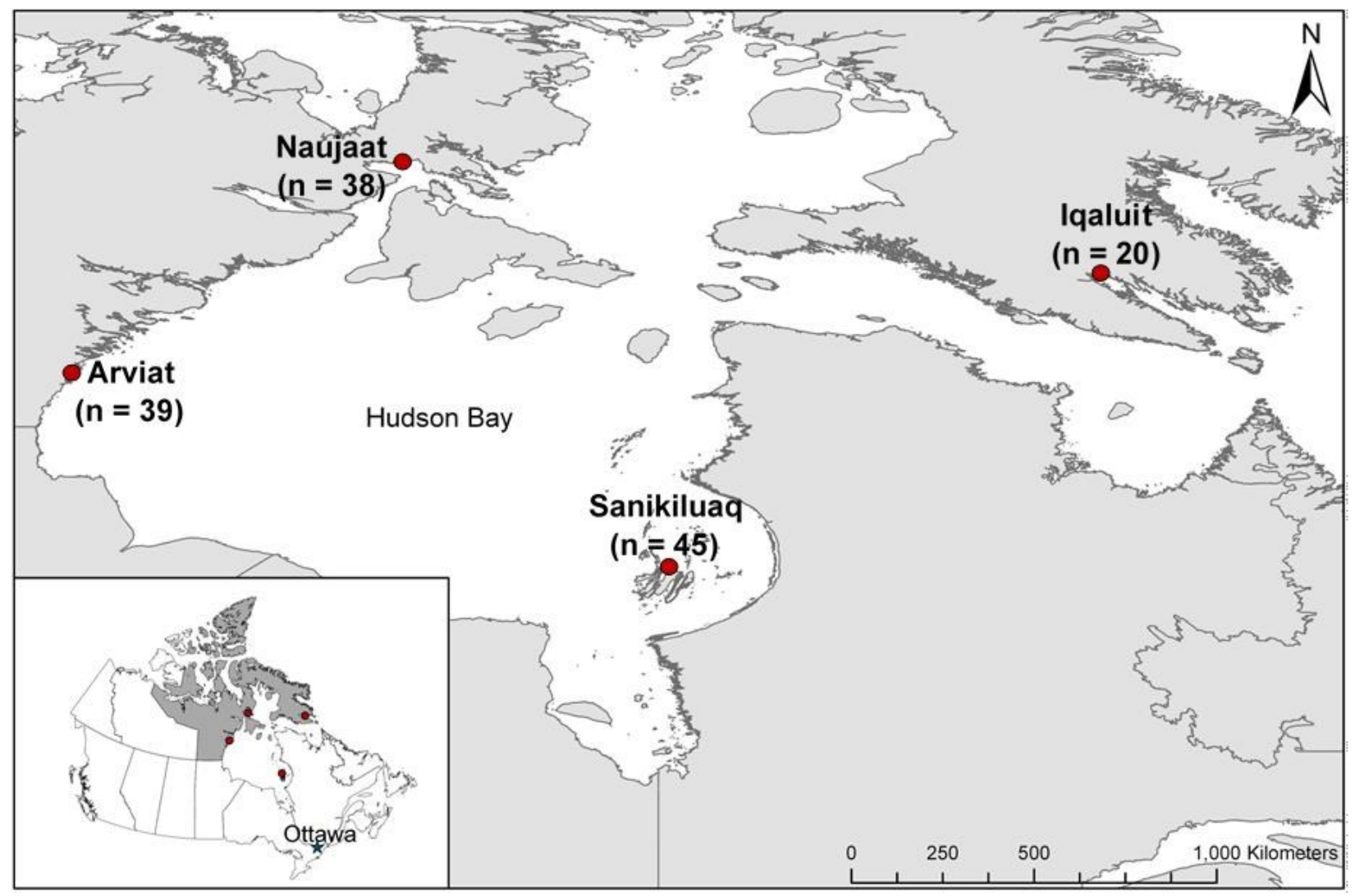

Figure 3.1: Locations in Nunavut, Canada, where Inuit subsistence hunters collected seal stomachs for this study: Arviat $\left(61.1078^{\circ} \mathrm{N}, 94.0624^{\circ} \mathrm{W}\right)$; Naujaat $\left(66.5283^{\circ} \mathrm{N}, 86.2447^{\circ} \mathrm{W}\right)$; Sanikiluaq $\left(56.5408^{\circ} \mathrm{N}, 79.2232^{\circ} \mathrm{W}\right)$; and Iqaluit $\left(63.7467^{\circ} \mathrm{N}, 68.5170^{\circ} \mathrm{W}\right)$. The numbers of seals collected from each location are indicated on the map. 


\subsection{Results}

This study focused on the ingestion and retention of plastics $>425 \mu \mathrm{m}$ in size, as the sampling methodology, specimen storage, and size of the stomachs would have made analysis of smaller plastic particles difficult given uncertainties around airborne contamination by microfibres (Torre et al., 2016) and the amount of organic material that would require digestion in order to isolate these smaller plastics (Lusher et al., 2017). Due to the uncertainties of atmospheric contamination by microfibres (both at the time of sampling and in the laboratory) we did not quantify microfibres in the stomach contents although a few were visible under the microscope. Although we are confident in the caution exerted in inspecting the sieves, we acknowledge that without conducting a digestion of the stomach contents, it is possible that small clear film-like plastics could have been overlooked amongst the organic prey items.

Of the 142 seal stomachs, the majority were from ringed seals $(n=135)$, along with some bearded seals $(n=6)$ and a single harbour seal $(n=1)$. The harvested seals ranged in age from juvenile to 30 years old and of the harvested seals there were 61 female, 78 male, and 3 unknown (Table 3.1 with full dataset in Table 7.2). The standard length of the seals ranged from $77 \mathrm{~cm}$ to $252 \mathrm{~cm}($ mean $=111 \mathrm{~cm})$. The weight of the seal stomachs ranged from $123 \mathrm{~g}$ to $6210 \mathrm{~g}(\mathrm{mean}=$ $494 \mathrm{~g}$ ). The weight of stomach contents ranged from $0 \mathrm{~g}$ to $3446 \mathrm{~g}$ (mean $=148 \mathrm{~g}$ ). Approximately $21 \%(n=31)$ of the seal stomachs were empty, which is similar to what has been reported in other seal diet studies (Gjertz and Lydersen, 1986; Holst et al., 2001; Labansen et al., 2007; Ogloff et al., 2019; Siegstad et al., 1998). The contents of the seal stomachs were fairly homogenous with either exclusively euphausiids $(n=60)$ or exclusively small fish $(n=19)$ making up the bulk of the stomach contents, however, a few stomachs had a mix of euphausiids and fish $(n=9)$ (Figure 3.2A, Figure 3.2B [I, II]). Less prevalent stomach contents included 
parasitic roundworms $(n=10)$, kelp $(n=2)$, and rocks $(n=1)$ (Figure 3.2A, Figure 3.2B [III, IV, V]). Four of the six bearded seal stomachs only contained large quantities of parasitic roundworms, while one contained fish and the other contained a large amount of sand, gravel and larger rocks, together weighing approximately $3.4 \mathrm{~kg}$ (Figure 3.2B [V, VI]). The harbour seal stomach contained fish. The stomach contents of a few seals $(n=10)$ were not identifiable given the state of digestion.

Table 3.1: Distribution of species and sex of seals harvested from four communities in Nunavut, Canada between 2007 and 2019.

\begin{tabular}{lccccccc}
\hline Community & Year & \multicolumn{3}{c}{ Species } & \multicolumn{3}{c}{ Sex } \\
\hline Arviat & & Ringed & Bearded & Harbour & Male & Female & Unknown \\
& 2008 & 32 & 5 & 1 & 18 & 19 & 1 \\
Naujaat & 2018 & 1 & 0 & 0 & 0 & 0 & 1 \\
Sanikiluaq & 2008 & 38 & 0 & 0 & 18 & 19 & 1 \\
& 2007 & 33 & 1 & 0 & 21 & 13 & 0 \\
Iqaluit & 2008 & 11 & 0 & 0 & 7 & 4 & 0 \\
& 2018 & 18 & 0 & 0 & 12 & 6 & 0 \\
\hline
\end{tabular}




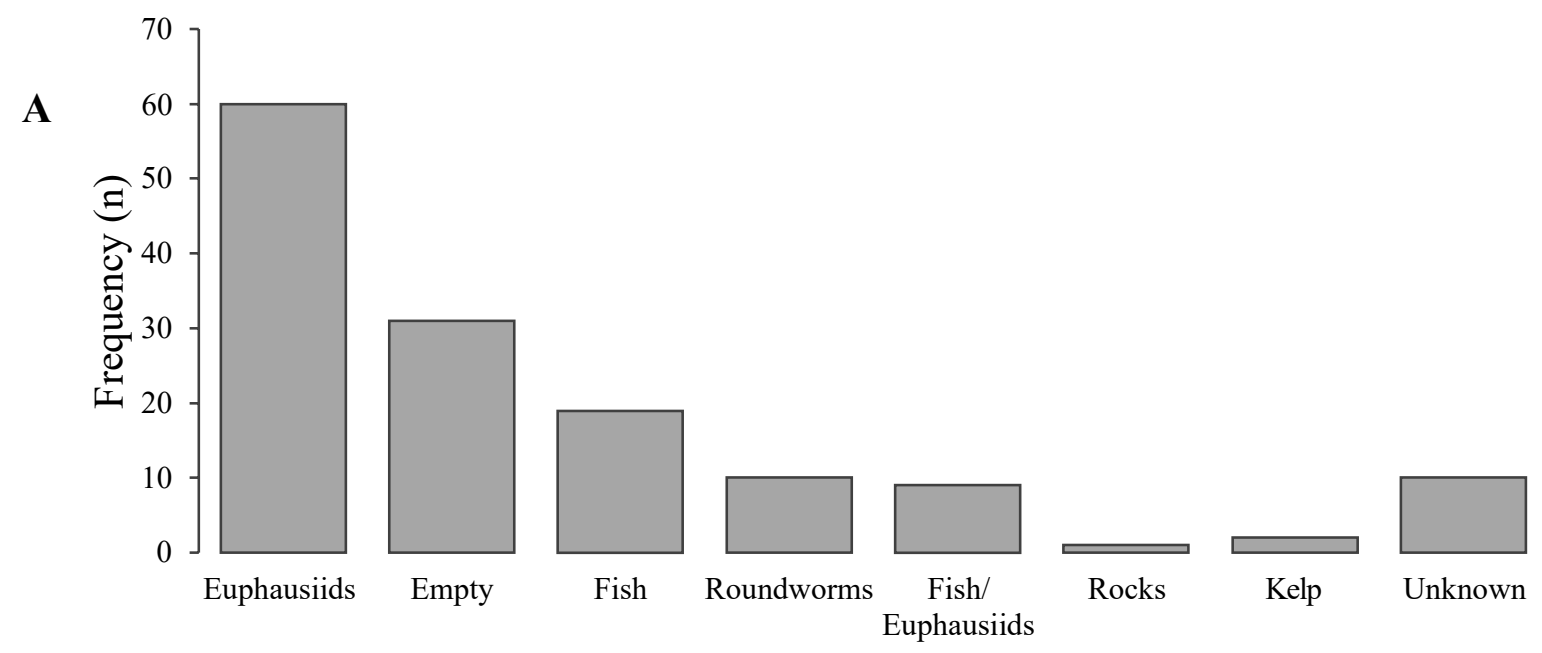

Dominant stomach contents

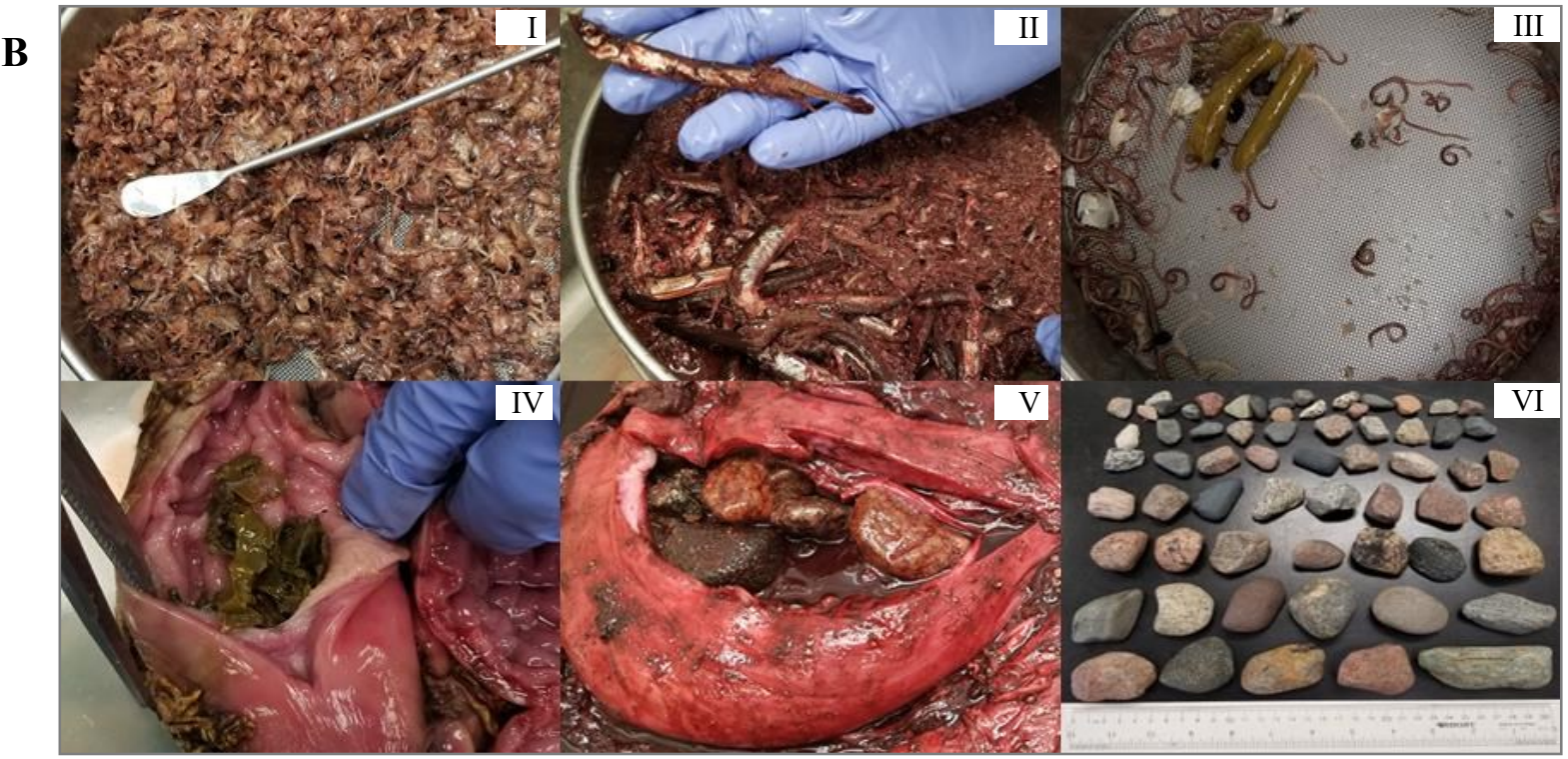

Figure 3.2: Stomach contents from the 142 seals examined for this study. A: the frequency distribution of dominant stomach contents from the 142 seals. B: the dominant stomach contents observed during dissections, including euphausiids (I), fish (II), roundworms (III), kelp (IV), and rocks (V). (VI) shows the large rocks removed from the same stomach shown in (V). 


\subsection{Discussion}

We detected no accumulated plastic particles $>425 \mu \mathrm{m}$ in the stomachs examined, which suggests that seals in the eastern Canadian Arctic are not retaining plastics in their stomachs. Although our study does not rule out the possibility that seals may be ingesting plastics that are passing through their digestive system, our fairly large sample size $(n=142)$ and the absence of plastic in any of the samples suggests a low ingestion rate of larger plastics, if any. These results indicate that unlike Arctic seabirds collected from the same region, seals are 1) not as exposed to plastic pollution when feeding; 2) not ingesting plastics if they are exposed to plastic pollution when feeding; and/or 3) not retaining plastics in their gastrointestinal systems. Furthermore, these results provide important baseline data for plastic retention in seal stomachs that can be used to assess future rates of plastic ingestion/retention in seals as the concentration of plastic pollution in the Arctic increases.

Previous studies have reported on plastic ingestion by fur seals (Arctocephalus ssp.) from the Southwestern Atlantic Ocean, the Eastern Pacific Ocean, and the Southwestern Pacific Ocean (Denuncio et al., 2017; Donohue et al., 2019; Eriksson and Burton, 2003), Hooker's sea lions (Phocarctos hookeri) from the Southwestern Pacific Ocean (McMahon et al., 1999), grey seals (Halichoerus grypus) from the Celtic and North seas (Hernandez-Milian et al., 2019; Nelms et al., 2019, 2018; Unger et al., 2017), harbour seals from the North Sea (Bravo Rebolledo et al., 2013; Nelms et al., 2019; Unger et al., 2017), and Mediterranean monk seals (Monachus monachus) from the Aegean Sea (Salman et al., 2001). Six of these studies found plastics in the stomachs and gastrointestinal tracts (GITs) of the sampled seals, and three studies found plastics in seal scat. Denuncio et al. (2017), Salman et al. (2001), and Unger et al. (2017) found macroplastics in the seal stomachs and GITs, which were predominately fishing-related debris, 
while Bravo Rebolledo et al. (2013), Hernandez-Milian et al. (2019), and Nelms et al. (2019) found microplastics in the stomachs and/or GITs of seals, of which the most common particles were fibres followed by fragments.

It has been suggested that the microplastics found in seal scat originated from secondary ingestion whereby the seals ingested prey already containing the plastic particles (Donohue et al., 2019; Eriksson and Burton, 2003; Nelms et al., 2018). McMahon et al. (1999) reported on microplastics in $11.5 \%$ of scats collected from Hooker's sea lions on Macquarie Island, also suggesting secondary ingestion of plastics after plastic fragments were found concurrently with otoliths from lanternfish (Electrona subaspera). Although the frequency of occurrence has been shown to be low, Kühn et al. (2018) and Morgana et al. (2018) both reported on plastics in polar cod (Boreogadus saida), a species commonly preyed upon by Arctic seals, highlighting the potential for Arctic seals to ingest microplastics through their prey. Similarly, low numbers of macro- and/or microplastics have been reported in the GITs of other marine mammals such as cetaceans (Lusher et al., 2018; Moore et al., 2020; Panti et al., 2019; Unger et al., 2017; van Franeker et al., 2018), suggesting fairly widespread exposure of marine mammals to plastics. Although plastics were found in all of the above studies, many of these authors noted the low occurrences of macro- and/or microplastics in stomachs and GITs, and suggested that plastics may not be retained for long periods of time in the GITs.

While seals are readily available in the region for monitoring chemical contaminants (Houde et al., 2017), the lack of plastic ingestion may indicate that seals may be less useful for tracking plastic pollution in the region. Importantly, most plastic debris either floats at the surface (e.g. polypropylene) or sinks to the bottom (e.g. polyvinyl chloride). The finding of mostly euphausiids in the diet suggests that the ringed seals are likely feeding in the middle of 
the water column, and thus are less likely to be exposed to plastic debris. In seabirds, similar trends have been found with surface feeders having the most plastic ingestion, whereas benthic and pelagic feeders having less accumulation of plastics (Poon et al., 2017; Provencher et al., 2014).

Although there was no evidence of plastic material in any of the stomachs dissected for this study, it is possible that there could have been microplastics $<425 \mu \mathrm{m}$ that were not captured in the sieves, and which would have likely passed through the GIT of the seals. It is also possible that the prey within the seal stomachs (euphausiids and fish) could have contained microplastics, thus contributing to an indirect ingestion of microplastics by the seals. Although Arctic waters have been suggested as a final resting place for some plastic debris, the concentration of plastics in Canada's eastern Arctic waters are likely lower than in temperate or equatorial areas (Cózar et al., 2017), possibly resulting in marine mammals such as seals being less exposed to plastics. This study therefore provides important baseline data for plastic ingestion and concentrations in the eastern Canadian Arctic.

Numerous studies have reported plastic ingestion by a variety of organisms, however, few studies have published results showing zero plastic ingestion rates. Liboiron et al. (2018) published findings of zero percent plastic ingestion rates of silver hake (Merluccius bilinearis) from off the south coast of Newfoundland, Canada, while Ryan et al. (2016) published their findings of zero plastic particles in Antarctic fur seal scat from three islands in the Indian and South Atlantic Oceans. Both of these articles suggest that there is a general lack of reporting null results of plastic ingestion within the literature. In order to gain a complete understanding of the extent of plastic pollution and to mitigate the impacts on the environment, it is paramount that we identify the species and regions in which plastic ingestion is occurring. 


\subsection{Acknowledgements}

We would like to thank all of the Inuit hunters that contributed samples to the different contaminant and health research programs over the years. In particular we would like to thank the Hunter and Trapper groups that supported the project; the Arviat Hunter and Trapper Organization, the Arviq Hunter and Trapper Organization, the Sanikiluaq Hunter and Trapper Association, and the Amaruq Hunter and Trapper Organization. Some of the samples were collected as part of work carried out with support from the Northern Contaminants Program under Crown and Indigenous Relations and Northern Affairs Canada. Support was also provided by the National Science and Engineering Research Council (NSERC), the Northern Student Training Program (NSTP), Fisheries \& Oceans Canada, Nunavut Wildlife Management Board, Nunavut Research Institute in partnership with Irving Shipbuilding Inc., and Coastal Environmental Baseline Program. Special thanks to Pierre-Yves Daoust and Jan van Franeker for providing helpful comments on the manuscript. 


\section{Breeding Seabirds as Vectors of Microplastics From Sea to Land: Evidence From Colonies in Arctic Canada}

Madelaine P.T. Bourdages ${ }^{1}$, Jennifer F. Provencher ${ }^{2}$, Julia E. Baak ${ }^{3}$, Mark L. Mallory ${ }^{3}$, Jesse C. Vermaire $^{1,4}$

${ }^{1}$ Carleton University, Geography and Environmental Studies, 1125 Colonel By Drive, Ottawa, ON K1S 5B6, Canada

${ }^{2}$ Environment and Climate Change Canada, National Wildlife Research Centre, 1125 Colonel By Drive, Ottawa, ON K1S 5B6, Canada

${ }^{3}$ Acadia University, Biology Department, 15 University Drive, Wolfville, NS B4P 2R6, Canada

${ }^{4}$ Carleton University, Institute for Environmental and Interdisciplinary Sciences, 1125 Colonel By Drive, Ottawa, ON K1S 5B6, Canada

This paper has been submitted to Science of the Total Environment - Plastic Pollution in the Arctic special issue. 


\subsection{Introduction}

Plastic debris is ubiquitous across marine and terrestrial habitats, and marine plastic pollution has been identified as an environmental concern largely due to its abundance and persistence in the environment (Gall and Thompson, 2015). Plastics have been found in all environments on Earth, and the Arctic has recently been suggested as a potential sink of plastic and microplastic pollution (Cózar et al., 2017; Peeken et al., 2018). Plastic debris is known to have deleterious effects on a wide range of animals through entanglement and ingestion (Derraik, 2002; Gall and Thompson, 2015; Kühn et al., 2015; Laist, 1997), and these encounters have become more frequent over time (Gall and Thompson, 2015). With the increasing amount of studies examining the effects of plastic pollution in the environment, more and more species are being found entangled in and/or having ingested plastics (Gall and Thompson, 2015; Provencher et al., 2017).

The majority of studies on the ingestion of anthropogenic debris by biota in the Arctic have focused on seabirds (Provencher et al., 2017; Trevail et al., 2015). As such, some species of seabirds have been used as effective monitoring species for plastic pollution in the Arctic (Provencher et al., 2017). Ingestion of plastic pollution by seabirds in Canada has been recorded since the early 1960s (Rothstein, 1973; Threlfall, 1968), and since then, there have been many more studies that have reported ingestion of plastics by seabirds (Provencher et al., 2017). The ingestion of plastic pollution can have many detrimental effects including physical damage to the digestive tract (Carey, 2011; Kühn et al., 2015; Pettit et al., 1981), poor nutrition or starvation as a result of plastics obstructing the passage of food (Auman et al., 1997; Dickerman and Goelet, 1987; Pierce et al., 2004), and appetite suppression and reduced growth rates (Ryan, 1988; Sievert and Sileo, 1993). Studies have also found that both chemicals associated with plastic 
pollution and those that have adsorbed onto plastics prior to ingestion can be passed to the organisms that have ingested the plastics (Lavers et al., 2014; Lu et al., 2019; Tanaka et al., 2013; Teuten et al., 2009).

Northern fulmars (Fulmarus glacialis; hereafter referred to as fulmars) are known to ingest and accumulate large amounts of plastic (Avery-Gomm et al., 2018; Poon et al., 2017; Trevail et al., 2015; van Franeker et al., 2011; van Franeker and Law, 2015). Similarly, other species of seabirds such as the thick-billed murre (Uria lomvia; hereafter referred to as murres) have also been reported to ingest plastic debris (Bond et al., 2013; Provencher et al., 2010), however, surface feeding seabirds such as fulmars tend to ingest plastics more frequently than pursuit/diving feeders such as murres (O’Hanlon et al., 2017; Poon et al., 2017). Many studies that have looked at plastics in the Arctic have focused on larger, meso- and macroplastics, and much less is known about the ingestion, retention, excretion, and trophic transfer of microplastics (plastics smaller than $5 \mathrm{~mm}$ ) in Arctic environments (Provencher et al., 2019).

Recently, microplastics were detected in northern fulmar guano from the Labrador Sea (Provencher et al., 2018), suggesting that seabirds could be acting as vectors for transporting microplastics from marine to remote terrestrial environments. Researching the excretion of microplastics via seabird guano is of particular interest as seabirds are often colonial breeders, and are known to act as vectors for nutrients and contaminants from the marine environment and concentrating them in remote Arctic terrestrial environments around their colonies (Blais et al., 2007, 2005; Choy et al., 2010; Michelutti et al., 2009). However, there has yet to be any research quantifying the amount of microplastics that may be deposited through guano around seabird colonies. This is an important aspect of plastic pollution to consider as many seabird colonies are within protected areas where monitoring efforts are being established (Mallory et al., 2019). 
Further, assessing how seabirds excrete microplastics could potentially provide a less invasive method of monitoring plastic ingestion and accumulation (Provencher et al., 2018).

The objectives of this study were to quantify microplastic concentrations in the faecal precursors (i.e. guano) of two common Arctic seabirds (fulmars and murres), test if the microplastic concentration in the faecal precursors is correlated to the concentration of larger ingested plastic debris in the birds, and identify whether seabird guano could be used as a nonlethal sampling technique of plastic pollution accumulation in seabirds. We predicted microplastics to be found in the faecal precursors of both species, but that fulmars would on average have more microplastics in their guano than murres because of the reported higher accumulation rates of plastics in this species (Provencher et al., 2017). The fulmars that have previously been examined for plastic pollution in gastrointestinal tracts and guano from the Labrador Sea (Avery-Gomm et al., 2018; Provencher et al., 2018) had more accumulated plastics than the fulmars used in this current study (Baak et al., 2020). Therefore, we also predicted that the fulmars in this study would excrete fewer microplastics than what was shown in Provencher et al. (2018). By scaling up our estimates of microplastic concentration in guano with data on colony size and guano deposition rates we also provide the first estimates of microplastic deposition that may be occurring on remote Arctic seabird colonies via seabird guano. Together these data provide important information on the quantity and cycling of microplastic pollution in remote Arctic environments.

\subsection{Methods}

\subsubsection{Sample Collection}

In collaboration with local Inuit hunters from Qikiqtarjuaq, Nunavut, Environment and Climate Change Canada (ECCC) collected fulmars from a colony in the Qaqulluit National 
Wildlife Area $\left(67.2333^{\circ} \mathrm{N}, 62.4667^{\circ} \mathrm{W}\right)$ and murres from a colony in the Akpait National Wildlife Area $\left(66.9333^{\circ} \mathrm{N}, 61.7667^{\circ} \mathrm{W}\right)$, both located in Nunavut, Canada, in August 2018

(Figure 4.1). All seabird collections were conducted with the following approvals and permits: Canadian Council on Animal Care (CCAC) guidelines (Acadia University Permit ACC 02-18), federal permits for work on seabirds and within the National Wildlife Areas (ECCC NUNNWA-18-02, NUN-SCI-18-02), and territorial permits (GN-WL-2018-004; NIRB-17YN069; NPC-148645). The activities for this project were carried out in consultation and collaboration with the Sululiit Area Co-Management Committee (ACMC), which is made up of community members and representatives from ECCC who are responsible for managing the National Wildlife Area visited for this project. Upon collection, all seabird carcasses were stored in individual bags in coolers and given unique identification numbers. Carcasses were then kept at $3-4^{\circ} \mathrm{C}$ until they were frozen within $72 \mathrm{~h}$ of collection.

The birds were transported frozen to the Nunavut Arctic College in Iqaluit, Nunavut, to be dissected and assessed by Environmental Technology Program students (Provencher et al., 2013). Detailed dissection methods can be found in Baak et al. (2020). Briefly, the gastrointestinal tracts (GIT; proventriculus, gizzard, intestines) of each bird was removed and shipped frozen to Acadia University, Wolfville, Nova Scotia, Canada, for dissection. The sex and various morphometric features were recorded during initial dissections. During dissections of the GIT, the last approximately $10 \mathrm{~cm}$ of the GIT including a segment of the small intestine and the cloaca (hereafter referred to as the faecal precursor sample, see Provencher et al., 2018) were removed, re-frozen and shipped to Carleton University, Ottawa, Ontario, Canada, to be analysed for microplastics. We obtained both GIT and faecal precursor samples from a total of 27 fulmars and 30 murres. 


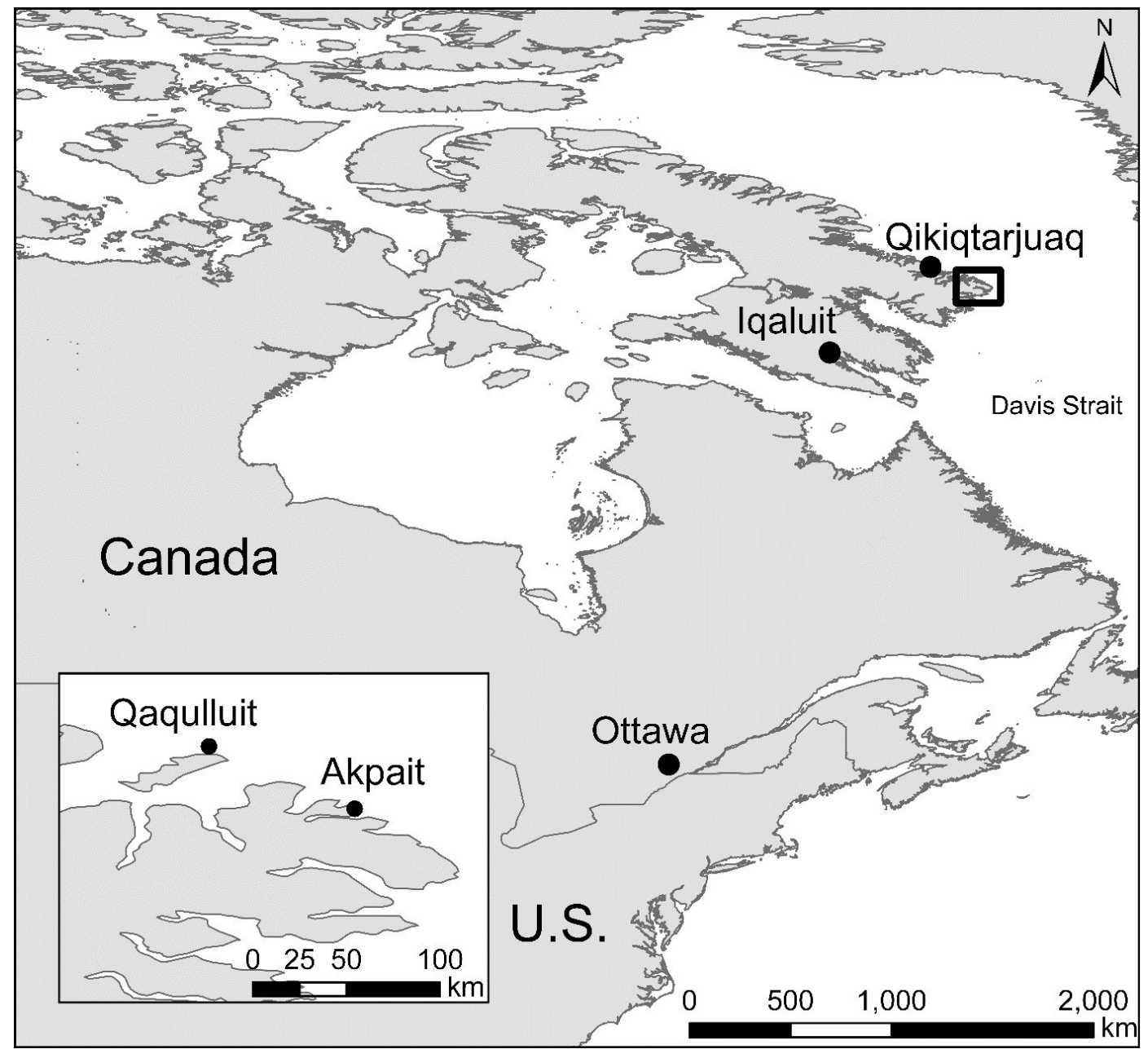

Figure 4.1: Map showing the Qaqulluit and Akpait National Wildlife Areas (NWA) located near Qikiqtarjuaq, Nunavut in the eastern Canadian Arctic. In August 2018, northern fulmars were collected from the Qaqulluit NWA (67.2333 $\left.\mathrm{N}, 62.4667^{\circ} \mathrm{W}\right)$ and thick-billed murres were collected from the Akpait NWA $\left(66.9333^{\circ} \mathrm{N}, 61.7667^{\circ} \mathrm{W}\right)$.

\subsubsection{Sample Processing}

At Carleton University faecal precursor samples were placed into separate clean beakers and chemically digested in $10 \%$ potassium hydroxide $(\mathrm{KOH})$ heated to $50^{\circ} \mathrm{C}$ for 24 to $48 \mathrm{~h}$, until most of the organic material was visibly removed. Once digestion was complete, the samples were filtered through clean $80 \mu \mathrm{m}$ nylon mesh filters $(\mathrm{MS} \circledast$ Nylon Mesh Filter, Membrane Solutions). Under a Leica stereo-microscope, suspected plastic particles were counted, 
categorized by broad colours (see Provencher et al., 2017) and category (fibre, fragment, film and foam), placed onto double sided tape using forceps, and photographed using Leica LAS EZ software. Any particles that were visually suspected as potentially being anthropogenic were picked from the filters for later chemical identification.

All suspected plastic particles were chemically identified using micro-Raman spectroscopy at the University of Toronto (Xplora Plus; Horiba Scientific with LabSpec 6 software) by matching the spectra using various spectral libraries. Since the total count of microplastics found in the samples was relatively low, all particles were identified with spectroscopy. Particles were categorized by polymer type, or as anthropogenic cellulosic

(cellulose fibre that is visibly recognized as being dyed), cellulose (cellulose fibre without obvious dye), synthetic dye (where spectra only matched with a synthetic dye), anthropogenic unknown (where a match was unsuccessful but the particle colour is clearly unnatural), and unknown (where a match was unsuccessful but the particle colour was not clearly unnatural).

\subsubsection{QA/QC for Microplastics}

To reduce any procedural contamination from airborne fibres, all tools, glassware and equipment were washed and triple rinsed with deionized (DI) water prior to use and in between samples. Glassware was promptly covered with clean aluminum foil to reduce exposure to air. Work areas were thoroughly wiped down with DI water before any work was done, and all filtering and microscopy work occurred under a clean air vertical flow workstation equipped with a HEPA filter (DFMZ model CAW4-V). White cotton lab coats were also worn whenever handling samples and six laboratory blanks using DI water in clean beakers were taken to estimate potential contamination in the laboratory (one laboratory blank for approximately every 10 samples). A total of 13 microfibres were recovered from the six laboratory blanks (mean of 
2.2 particles per blank) that included 3 black, 5 blue, 1 brown, 1 pink, and 3 white fibres. These microfibres were subtracted based on colour from the samples that corresponded to the specific blanks where the microfibres were found. No other anthropogenic particle type was recovered from the blanks.

\subsubsection{Data Analysis}

The frequency of occurrence (FO) of plastics in the GITs and faecal precursor samples were calculated with a $95 \%$ confidence interval using Jeffreys interval. To test the relationship between larger plastics in the GIT and microplastics in the faecal precursor samples for each species, the FO of plastics in the faecal precursor samples were analysed using a Generalized Linear Model (GzLM) with a binomial distribution and logit function, with the FO of plastics in the stomachs as a predictor. The FO of plastics in the GITs and in the faecal precursor samples were also analysed using a GzLM with species and sex as predictors. All statistical analyses were conducted using R statistical environment version 3.6.3 (R Core Team, 2020).

\subsubsection{Estimates of Microplastics Deposited Around the Colonies}

Using the faecal precursor data from the fulmars and murres, as well as population surveys conducted at the bird colonies in 2018 (Mallory et al., 2020a), we estimated how many microplastics could be deposited to the environment surrounding these colonies annually. In 2018, the colony in the Qaqulluit National Wildlife Area was occupied by 25,000 breeding pairs of northern fulmars (Mallory et al., 2020a). Fulmars are typically at the colony for approximately 75 days during the breeding period, and both parents are rarely present at the same time (Gaston et al., 2006; Mallory et al., 2020b). Although the first incubation shift by the males tends to be longer, average incubation shifts for the fulmars is approximately 5 days (Mallory, 2009), thus only one member of each pair is at the colony for approximately 5 days at a time. Excretion 
frequencies or habits have not been quantified for northern fulmars, however, Hilton et al. (2000) observed an approximately 10 hour retention time for fulmars during a study on North Atlantic seabird digestion, and indicated that guano was collected at approximately 2-3 hour intervals for more than 19 hours after ingestion. Fulmars at the Qaqulluit colony have been observed to excrete upon leaving the colony during switch overs with their mate (Mallory, unpubl. data), though the birds are likely to excrete during the first 24 hours following the return of their foraging period, depending on when their last feeding occurred. Given the data from Hilton et al. (2000), we estimate that the fulmars excrete approximately 10 times per incubation shift ( $\sim 5$ days), and since the birds are at the colony for approximately 75 days, each pair of fulmars would excrete at least 150 times at the colony during the season. To calculate the amount of microplastics potentially being deposited into the environment surrounding the colony, we multiplied the frequency of excretion (150 times) by the population (25,000 pairs), and then by the mean count of particles per bird (0.89). We also use the above equation with the $95 \%$ confidence interval of the mean (0.43) to calculate the confidence interval of our estimate of particle deposition.

The population of thick-billed murres at the Akpait colony is estimated to be around 130,000 pairs (Gaston et al., 2012), and these birds inhabit the colony on average for approximately 53 days during the breeding period (Gaston et al., 2006; Gaston and Hipfner, 2020). Unlike the fulmars who take longer incubation periods, the incubation shifts for murres average around $12 \mathrm{~h}$ (Gaston et al., 2013). In the study by Hilton et al. (2000), the common murre (Uria aalge) had an approximately 6 hour retention time as well as one of the highest cumulative guano outputs with over 12 grams of guano produced in 12 hours from their last meal. Since the common murre is closely related to the thick-billed murre (Birkhead and 
Nettleship, 1987), we assume that these data can be relatively comparable to that of the thickbilled murre. Guano was collected at the same frequency as for the fulmars (Hilton et al., 2000), therefore we are estimating that the murres also excrete at least 10 times following their feeding, most of which would likely occur at the colony during their incubation shift. Thus, we estimate that the murres excrete approximately 10 times per incubation shift ( $\sim 12$ hours), and since the birds are at the colony for approximately 53 days, each pair of murres would excrete at least 1060 times at the colony during the breeding season. We use the same calculation as with the fulmars and multiply the frequency of excretion (1060 times) by the population (130,000 pairs), and then by the mean count of particles per bird (0.33). Again, we then use the $95 \%$ confidence interval of the mean (0.34) in the equation to calculate the confidence interval of our estimate of particle deposition.

\subsection{Results}

All particles from the GITs and faecal precursor samples were categorized as user plastics, however, particle shape classifications ranged between stomachs and faecal precursor samples (Figure 4.2; Table 4.1 with full dataset of particle counts and shape categories in Table 7.3). Sixty-one particles were picked from the filters and identified via micro-Raman spectroscopy (46 from the fulmar samples and 15 from the murre samples). Of these particles, 34 were confirmed as anthropogenic ( 24 from the fulmars and 10 from the murres). The other 27 particles were either identified as cellulose or unknown. Anthropogenic particles from the fulmar faecal precursors were dominated by synthetic dyes (Figure 4.3), whereas the murre faecal precursors were dominated by anthropogenic unknown particles, followed by polyethylene particles (Figure 4.4). A full list of the shape, colour, and polymer classification of all anthropogenic particles found in the bird faecal precursors is provided in Table 7.4. 
A

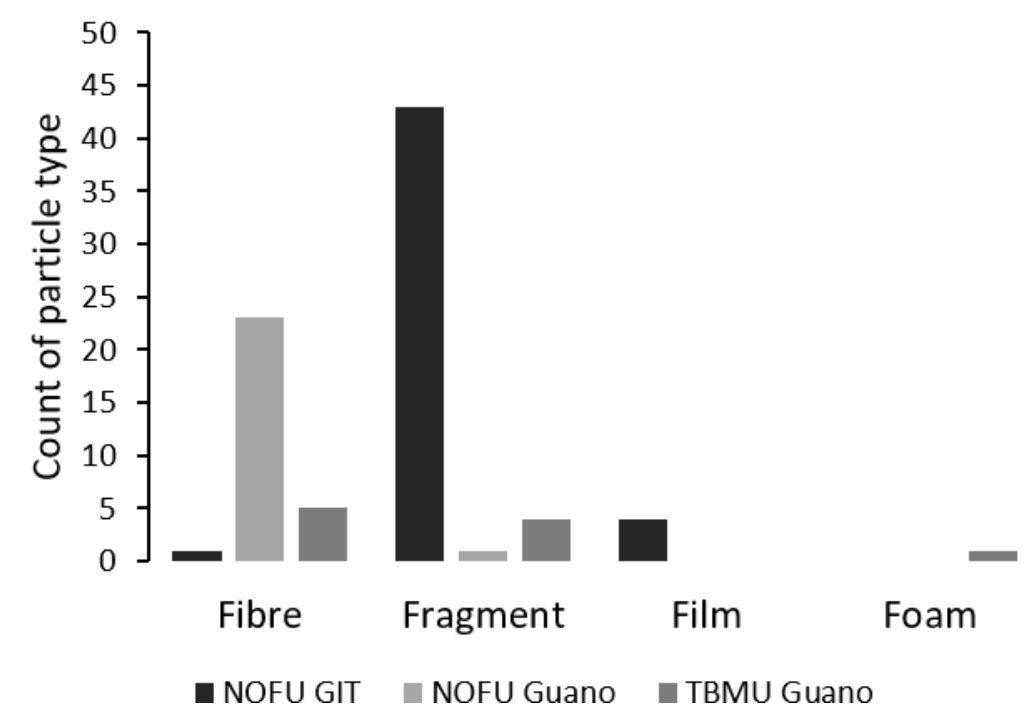

B

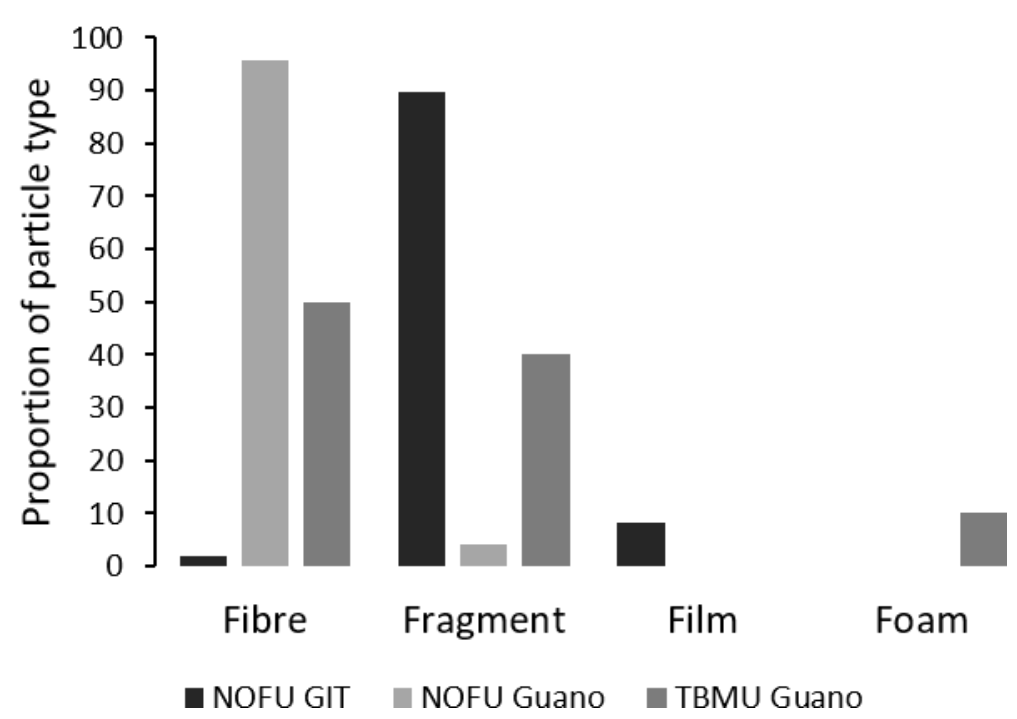

Figure 4.2: Distribution of particle shape categories from the stomach and faecal precursor samples of northern fulmars (NOFU) and thick-billed murres (TBMU), with (A) showing the count of particles and (B) showing the proportion of particles. 


\section{Northern fulmar (Fulmarus glacialis)}
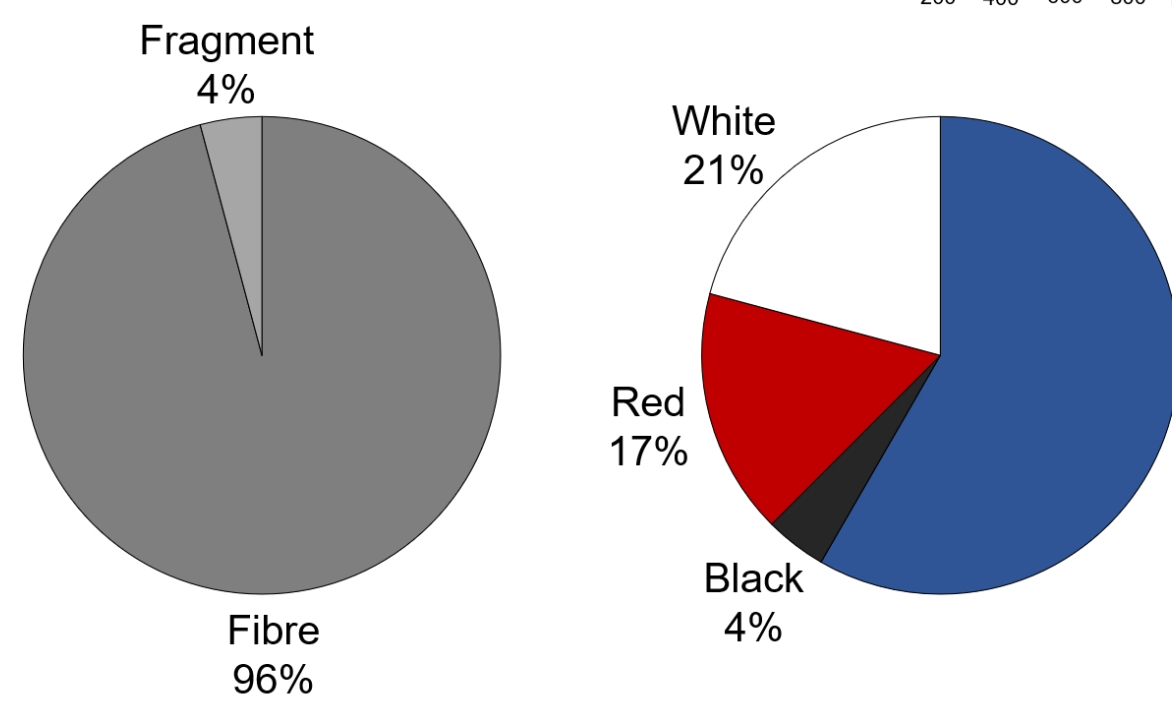
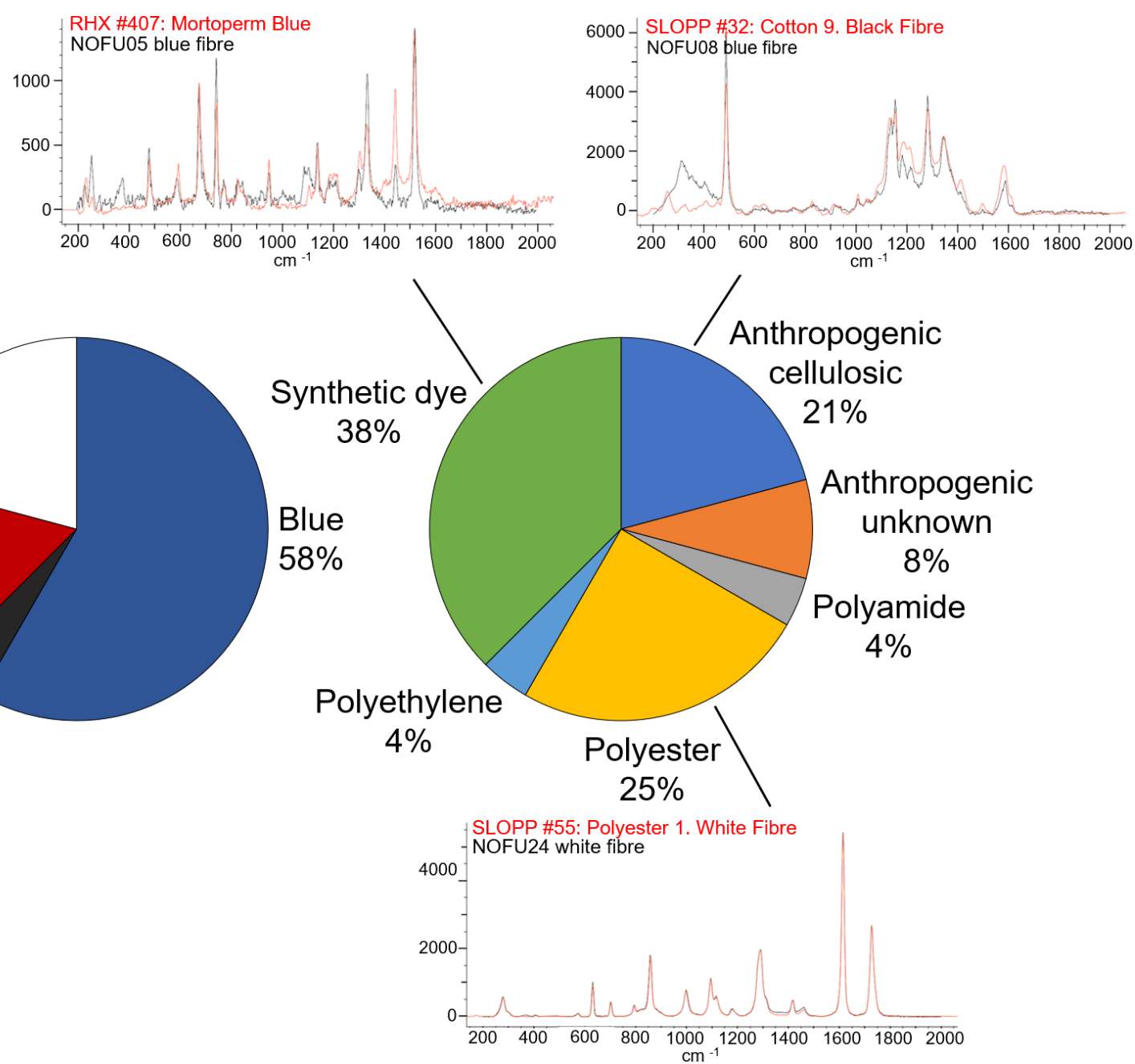

Figure 4.3: Shape categories, colours, and chemical classifications of particles recovered from the faecal precursor samples of northern fulmars. Examples of spectral matches from micro-Raman spectroscopy are provided for different chemical classification types. Each black wavelength represents a sample particle spectrum and each red wavelength represents a known spectrum from the spectral libraries. The $\mathrm{x}$-axes show the wavelengths $\left(\mathrm{cm}^{-1}\right)$ and the y-axes show the Raman intensity. 


\section{Thick-billed murre (Uria lomvia)}
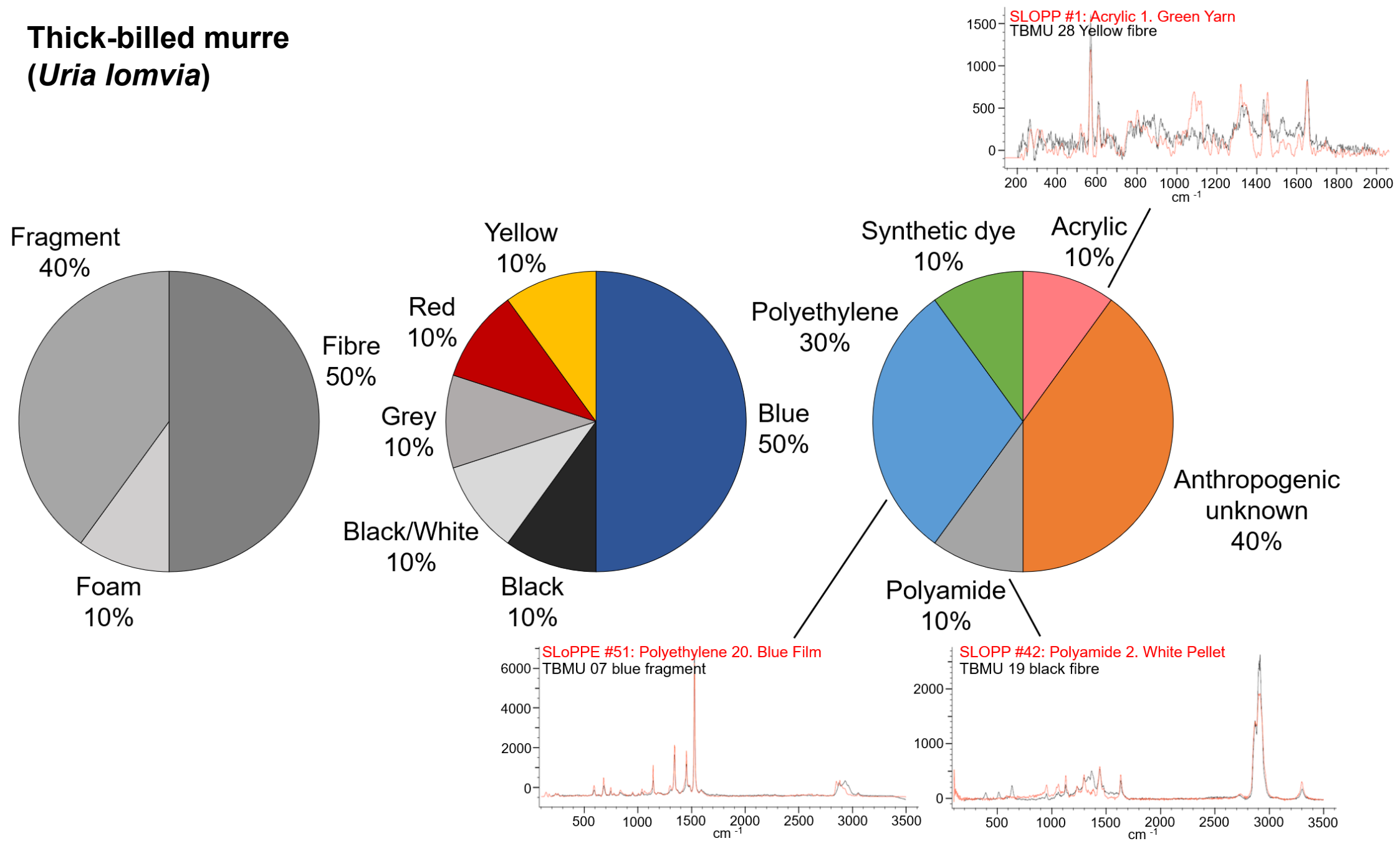

Figure 4.4: Shape categories, colours, and chemical classifications of particles recovered from the faecal precursor samples of thickbilled murres. Examples of spectral matches from micro-Raman spectroscopy are provided for different chemical classification types. Each black wavelength represents a sample particle spectrum and each red wavelength represents a known spectrum from the spectral libraries. The $\mathrm{x}$-axes show the wavelengths $\left(\mathrm{cm}^{-1}\right)$ and the $\mathrm{y}$-axes show the Raman intensity. 
Table 4.1: Count, frequency of occurrence (with Jeffreys 95\% confidence interval), mean, median, and range of all anthropogenic particles and different categories of particles recovered from the stomachs (Baak et al., 2020) and faecal precursor samples of northern fulmars and thick-billed murres collected in August 2018 from two colonies near Qikiqtarjuaq, Nunavut.

\begin{tabular}{|c|c|c|c|c|}
\hline & \multicolumn{2}{|c|}{ Northern fulmar } & \multicolumn{2}{|c|}{ Thick-billed murre } \\
\hline & Stomach & $\begin{array}{l}\text { Faecal } \\
\text { precursor }\end{array}$ & Stomach & $\begin{array}{l}\text { Faecal } \\
\text { precursor }\end{array}$ \\
\hline \multicolumn{5}{|c|}{$\begin{array}{l}\text { All anthropogenic } \\
\text { particles }\end{array}$} \\
\hline$n$ & 48 & 24 & 0 & 10 \\
\hline FO $(95 \%)$ & $74(56-88)$ & $56(37-73)$ & 0 & $17(7-33)$ \\
\hline Mean (SD) & $1.8(1.6)$ & $0.9(1.1)$ & NA & $0.3(0.9)$ \\
\hline Median & 1 & 1 & 0 & 0 \\
\hline Range of \# & $0-6$ & $0-4$ & 0 & $0-4$ \\
\hline \multicolumn{5}{|l|}{ Fragment } \\
\hline$n$ & 43 & 1 & 0 & 4 \\
\hline FO $(95 \%)$ & $74(56-88)$ & $4(0-16)$ & 0 & $7(1-20)$ \\
\hline Mean (SD) & $1.6(1.5)$ & $0.04(0.2)$ & NA & $0.1(0.6)$ \\
\hline Median & 1 & 0 & 0 & 0 \\
\hline Range of \# & $0-6$ & $0-1$ & 0 & $0-3$ \\
\hline \multicolumn{5}{|l|}{ Fibre } \\
\hline$n$ & 1 & 23 & 0 & 5 \\
\hline FO $(95 \%)$ & $4(0-16)$ & $56(37-73)$ & 0 & $10(3-24)$ \\
\hline Mean (SD) & $0.04(0.2)$ & $0.9(1.0)$ & NA & $0.2(0.6)$ \\
\hline Median & 0 & 1 & 0 & 0 \\
\hline Range of \# & $0-1$ & $0-4$ & 0 & $0-3$ \\
\hline \multicolumn{5}{|l|}{ Film } \\
\hline$n$ & 4 & 0 & 0 & 0 \\
\hline FO $(95 \%)$ & $7(2-22)$ & 0 & 0 & 0 \\
\hline Mean (SD) & $0.2(0.6)$ & NA & NA & NA \\
\hline Median & 0 & 0 & 0 & 0 \\
\hline Range of \# & $0-3$ & 0 & 0 & 0 \\
\hline \multicolumn{5}{|l|}{ Foam } \\
\hline$n$ & 0 & 0 & 0 & 1 \\
\hline FO $(95 \%)$ & 0 & 0 & 0 & $3(0-15)$ \\
\hline Mean (SD) & NA & NA & NA & $0.03(0.2)$ \\
\hline Median & 0 & 0 & 0 & 0 \\
\hline Range of \# & 0 & 0 & 0 & $0-1$ \\
\hline
\end{tabular}


Anthropogenic particles were found in 74\% (20/27) of the fulmar GITs (see Baak et al., 2020 for a breakdown of categories) and in 56\% (15/27) of the fulmar faecal precursor samples, which is similar to the findings in Provencher et al., 2018 (Table 4.1). Primarily fibres were identified in the fulmar faecal precursor samples $(23 / 24 ; 96 \%)$ in addition to one fragment $(1 / 24$; 4\%; Figure 4.4a-b). None of the murres had plastics in their GITs, but $17 \%(5 / 30)$ of the murre faecal precursor samples contained anthropogenic particles. Fibres accounted for half of the particles recovered from the murre faecal precursor samples $(5 / 10)$, followed by fragments $(4 / 10$; $40 \%)$, and foam $(1 / 10 ; 10 \%$; Figure $4.4 c-d)$.

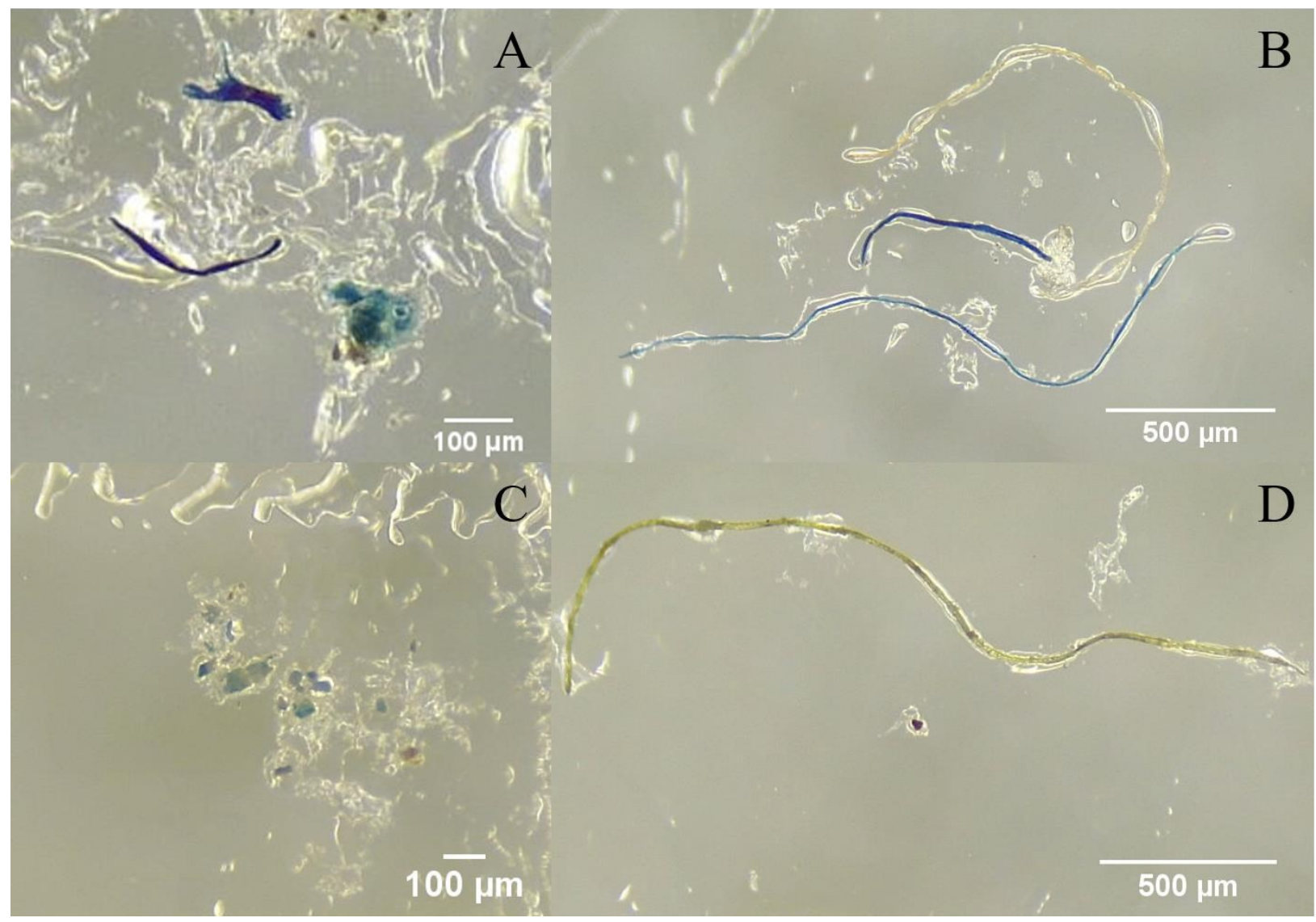

Figure 4.5: Examples of anthropogenic particles recovered from the faecal precursor samples of northern fulmars (A-B) and thick-billed murres (C-D). A: a blue synthetic dye fibre, an anthropogenic unknown fibre, and a blue polyethylene fragment. B: a white polyester fibre and two blue synthetic dye fibres. C: a blue polyethylene fragment. D: an acrylic yellow fibre. 
As predicted, the FO of anthropogenic particles in the fulmar faecal precursors was greater than the FO of particles in the murre faecal precursors (GzLM, $p<0.005$ ). However, the proportion of fulmars with plastics in their GIT did not significantly differ from the proportion of fulmars with plastics in their faecal precursors (GzLM, $p=0.92)$. Similar to how the FO of plastics in the GIT of fulmars did not differ between sex (Baak et al., 2020), there was no relationship in the FO of plastics in faecal precursors between sex for either fulmars (GzLM, $p=$ 0.38 ) or murres (GzLM, $p=0.41)$.

When we multiply the population with the frequency of excretion and mean count of anthropogenic particles per bird, we estimate that fulmars could potentially be depositing up to $3.34 \pm 1.61$ million anthropogenic particles around the colony in the Qaqulluit National Wildlife Area within the breeding period. When we run the same calculation for the murres as with the fulmars, we estimate that murres could be depositing approximately $45.5 \pm 46.9$ million anthropogenic particles annually around the colony in the Akpait National Wildlife Area via guano at the current levels of plastic pollution ingestion by this species. Since limited data exists for excretion frequencies and colony population variability during the breeding season, our calculations do not account for other potential sources of error. Calculations for each species are shown in Table 4.2. 
Table 4.2: Calculations for estimating the potential deposition of anthropogenic particles via guano for northern fulmars (NOFU) and thick-billed murres (TBMU) during the breeding season at colonies near Qikiqtarjuaq, Nunavut.

\begin{tabular}{cccccccccc}
\hline Species & $\begin{array}{c}\text { Population } \\
\text { (pairs) }\end{array}$ & $\begin{array}{c}\text { Frequency } \\
\text { of } \\
\text { excretion }\end{array}$ & $\begin{array}{c}\text { Mean count } \\
\text { of particles } \\
\text { / bird }\end{array}$ & $\begin{array}{c}\text { 95\% CI of the } \\
\text { mean count of } \\
\text { particles / bird }\end{array}$ & $\begin{array}{c}\text { Estimate } \\
\text { deposition of } \\
\text { anthropogenic } \\
\text { particles }\end{array}$ \\
\hline NOFU & 25,000 & $\mathrm{x}$ & 150 & $\mathrm{x}$ & 0.89 & $\mathrm{x}$ & $/$ & $=$ & $3,337,500$ \\
& 25,000 & $\mathrm{x}$ & 150 & $\mathrm{x}$ & $/$ & $\mathrm{x}$ & 0.43 & $=$ & $1,612,500$ \\
TBMU & 130,000 & $\mathrm{x}$ & 1060 & $\mathrm{x}$ & 0.33 & $\mathrm{x}$ & $/$ & $=$ & $45,474,000$ \\
& 130,000 & $\mathrm{x}$ & 1060 & $\mathrm{x}$ & $/$ & $\mathrm{x}$ & 0.34 & $=$ & $46,852,000$ \\
\hline
\end{tabular}

\subsection{Discussion}

The movement and cycling of plastic pollution in the environment has been recognized as a research priority for understanding how plastic pollution affects biota (ECCC, 2019;

Provencher et al., 2020b). We assessed the excretion of microplastics by two species of Arctic colonial seabirds known to ingest plastic pollution and accumulate it in their stomachs. We know that microplastics are in Arctic environments (e.g. Bergmann et al., 2017; Huntington et al., 2020; Lusher et al., 2015; Morgana et al., 2018; Peeken et al., 2018) and that seabirds move and concentrate nutrients and other contaminants from the marine environment to terrestrial and freshwater environments surrounding their colonies via their guano (e.g. Blais et al., 2005, 2007; Brimble et al., 2009; Choy et al., 2010; Hargan et al., 2017; Michelutti et al., 2009). Thus, we expect that these seabirds may similarly be concentrating microplastics in these environments. The movement of microplastics has been thought to be primarily from the terrestrial environment to the marine, but recent work has shown that microplastics may also move from the marine environment to the terrestrial landscapes (Allen et al., 2020). Our findings further support this idea that microplastics are likely transported back to land. 
We identified anthropogenic particles in the faecal precursor samples of both fulmars and murres, however, these particles were present in more of the fulmars than the murres. None of the murres had plastics in their GIT, but 17\% had anthropogenic particles in their faecal precursor samples, while $74 \%$ of the fulmars had plastics in their GIT and $56 \%$ had anthropogenic particles in their faecal precursor samples. Although murres have previously been found to ingest plastics (Bond et al., 2013; Provencher et al., 2010), these results were somewhat expected given the foraging methods of murres as they feed primarily in the middle of the water column (Bradstreet, 1980), a location where plastics do not readily accumulate as they are more likely to float or sink (Moser and Lee, 1992; Provencher et al., 2014). Studies have found that surface feeders (e.g. fulmars) have a greater frequency of plastic ingestion and accumulation as opposed to pursuit/diving feeders such as murres (O’Hanlon et al., 2017; Poon et al., 2017; Provencher et al., 2014).

Plastic pollution ingestion by seabirds has been widely studied and continues to be important to monitor. Currently the only way to accurately monitor accumulated plastics is through necropsy or regurgitation techniques (Provencher et al., 2017), however, finding a less invasive method to assess plastic ingestion would be beneficial. Recently, Provencher et al. (2020a) tested whether phthalate esters from northern fulmar preen oil could be used to assess the exposure to plastics; a method previously attempted with shearwaters and terns (Hardesty et al., 2015). Although Hardesty et al. (2015) identified a correlation between phthalates from the preen oil and counts of ingested plastics in certain birds, Provencher et al. (2020a) were unable to detect phthalate concentrations in northern fulmars that also had plastics in their GIT, indicating further need for monitoring alternatives. 
Provencher et al. (2018) examined the faecal precursors of 30 northern fulmars collected from the Labrador Sea in 2015 to assess the relationship between microplastics in guano and plastics in the bird GITs. Their study found plastics in $97 \%$ of the bird GITs and microplastics in $47 \%$ of the bird faecal precursor samples, suggesting that birds may be acting as vectors for transporting microplastics. Although there were slightly more fulmars in the current study that contained anthropogenic particles in their faecal precursor samples than in Provencher et al. (2018), we found a lower mean count of anthropogenic particles per bird ( 0.89 as opposed to 1.9 in Provencher et al., 2018). These differences could be attributable to trends that have indicated potentially lower rates of plastic ingestion by fulmars with increased latitude (Provencher et al., 2017). Additionally, in this study we chemically identified all particles from the faecal precursor samples using micro-Raman spectroscopy, which allowed us to exclude potentially natural particles from our analyses. Forty-four percent of the initial particles found on the filters were natural or unknown, highlighting the importance of particle identification to reduce overestimations of anthropogenic particles, especially when dealing with small particle sizes (Lenz et al., 2015; Munno et al., 2020).

Plastic pollution ingested by birds is thought to be retained in the gizzard and mechanically broken down over time until it is able to pass through the intestines and be excreted through the cloaca (Provencher et al., 2018; Reynolds and Ryan, 2018; van Franeker and Law, 2015). Although excreted microplastics may represent plastic pollution that has been retained and ground up by the gizzard, microplastics that are too small to be retained presumably represent a large portion of excreted microplastics (Provencher et al., 2018). This was the case in this study as none of the murres contained plastics in their GITs, yet microplastics and other anthropogenic particles were identified in their faecal precursor samples. As such, quantifying 
microplastics and other anthropogenic particles in seabird guano without inspection of GITs may not be a sufficient way of monitoring ingested and accumulated plastics, however, monitoring guano could be an important means of monitoring the distribution of microplastics in the environment.

From our calculations, seabird guano could represent an important vector of microplastic pollution in the Arctic environment. We estimated that breeding fulmars and murres may excrete up to $3.34 \pm 1.61$ and $45.5 \pm 46.9$ million anthropogenic particles, respectively, per year to the regions around their breeding colonies. Our estimates represent a range of the microplastics that could be deposited around colonies by these two seabird species. The frequency of excretion for the fulmars is very conservative as it does not account for the shorter incubation periods during chick rearing (Mallory, 2009), or the occasions where both members of the pair are at the colony. Although the frequency of anthropogenic particles is lower in murre guano than that of the fulmars, the population of the murre colony is far greater, as is the frequency of which murres excrete at the colony. As such, the deposition of anthropogenic particles we estimated is greater for the murres than the fulmars, which is slightly counter-intuitive given the accumulation levels of plastic pollution in these two species.

Chicks from many seabird species ingest plastics via parental feedings (e.g. Rapp et al., 2017; Rodríguez et al., 2012; van Franeker and Bell, 1988), most commonly of which are albatrosses (Diomedeidae spp.; Auman et al., 1997; Fry et al., 1987; Rapp et al., 2017; Sievert and Sileo, 1993) and shearwaters (Ardenna spp.; Carey, 2011; Cousin et al., 2015; Fry et al., 1987; Lavers et al., 2014; Verlis et al., 2018, 2013). Acampora et al. (2017) also found plastic pollution in chick regurgitates from black-legged kittiwakes (Rissa tridactyla), northern fulmars and great cormorants (Phalacrocorax carbo) from breeding colonies in Ireland. However, chicks 
from the Arctic have been largely understudied for plastic ingestion, and to our knowledge there are no studies that have assessed microplastics in chick guano. As such, the estimates we present do not account for the potential input from chick guano in either calculation, even though Arctic seabird chicks produce a large amount of guano (Stempniewicz, 1990).

Although these estimates portray seemingly large counts, they are still relatively low compared to other known inputs of microplastics to the environment. Wastewater effluent has been largely recognized as an important conduit for microplastic pollution in aquatic environments (Leslie et al., 2017; Mason et al., 2016; Talvitie et al., 2015; Vermaire et al., 2017; Ziajahromi et al., 2017). Although studies have found that conventional wastewater treatment is effective at removing up to $99 \%$ of microplastics (Gies et al., 2018; Murphy et al., 2016), because the volume of effluent discharged by wastewater treatment plants daily is so large, high quantities of microplastics can still be discharged into receiving waters (Talvitie et al., 2017). A recent report even estimates that municipal wastewater releases up to 3.5 quadrillion $\left(3.5 \times 10^{15}\right)$ microfibres into aquatic environments each year in Canada and the U.S.A. (Vassilenko et al., 2019). Much of the research investigating the input from wastewater treatment plants has focused primarily on areas with larger populations, therefore, the concentrations from these studies could be less representative in the Arctic where populations are smaller. However, other studies identify transport of plastics towards the Arctic via ocean currents (Cózar et al., 2017; Lusher et al., 2015b), and thus inputs from urban areas farther south are likely a source for Arctic plastic pollution, as suggested by Huntington et al. (2020).

Another potential input of microplastics in the Arctic is atmospheric deposition. Longrange transport of various contaminants to the Arctic via atmospheric deposition have been documented (Barrie et al., 1992; Cotham and Bidleman, 1991; Macdonald and Bewers, 1996; 
Zhang et al., 2013), therefore microplastics may be transported to the Arctic in the same way. Bergmann et al. (2019) found up to 14,000 microplastics per litre of Arctic snow, indicating that microplastics are likely being transported to the Arctic in the atmosphere before binding to snow and being deposited. Although sample volumes were low, Huntington et al. (2020) found one polyethylene fibre from snow samples collected in Alert, Nunavut, Canada. Atmospheric transport and deposition of microplastics to the Arctic is still an area needing further research, however, this phenomenon has been recorded in studies looking at other areas around the world including urban (e.g. Cai et al., 2017; Dehghani et al., 2017; Dris et al., 2016, 2015) and remote locations (e.g. Allen et al., 2019; Free et al., 2014). Reported concentrations of microplastics in urban areas have ranged from 2 to 355 particles $\mathrm{m}^{-2} \mathrm{~d}^{-1}$ in atmospheric fallout around Paris, France (Dris et al., 2016), and 88 to 605 microplastics per $30 \mathrm{~g}$ of urban dust in Tehran, Iran (Dehghani et al., 2017). Further, a remote mountain catchment in the French Pyrenees was reported to have an average atmospheric deposition of $365 \pm 69$ microplastic particles $\mathrm{m}^{-2} \mathrm{~d}^{-1}$ (Allen et al., 2019). When these reported values are scaled up to represent the larger areas of the seabird colonies, the potential daily values from atmospheric deposition would exceed the seasonal estimates of microplastics that are potentially being deposited via seabird guano around the two colonies in this study.

Although the field of plastic and microplastic pollution is growing, more work needs to be done to assess the sources, cycling and fate of microplastics in the Arctic. Results from the faecal precursor samples indicated that anthropogenic particles are being excreted by both species, however, since the murres had no plastics in their GITs, seabird guano may not be suitable as a standalone monitoring technique for accumulated plastics. Nonetheless, this study indicates that colonial seabirds could act as another important source of localized environmental 
microplastic contamination in the Arctic, as they do with chemical contaminants (e.g. Blais et al., 2005).

\subsection{Acknowledgments}

The Sululiit Area Co-Management Committee (ACMC), which is comprised of community members and representatives from Environment and Climate Change Canada who are responsible for managing the National Wildlife Areas visited for this project was consulted throughout the project. The authors are particularly appreciative to the sampling teams, including Jaypootee Aliqatuqtuq, Jonathan Aliqatuqtuq, Harry Alookie, Uluraik Amarualik, Stevie Aulaqiaq, Cody Dey, Catherine Geoffroy, Jaloo Kooneeliusie, Peter Kooneeliusie, and Jeanie Toomasie. Importantly, support in Qikiqtarjuaq was provided by the Nattivak Hunter and Trapper Organisation by Alison Kopalie and Members of the Board. Thanks also to Rian Dickson who supported the project through logistics coordination and community consultations. We would also like to thank Dr. Chelsea Rochman for providing the micro-Raman spectrometer used for particle identification, and to Bonnie Hamilton and other members of the Rochman Lab for providing training on the equipment. Funding for this work was provided by a network of partnerships that included Environment and Climate Change Canada, Nunavut Wildlife Management Board, Natural Sciences and Engineering Research Council of Canada, Acadia University, and Crown Indigenous Relations and Northern Affairs Canada. 


\section{Conclusion}

This thesis investigated how seals and seabirds from the eastern Canadian Arctic are currently interacting with plastic pollution. The primary objectives of this thesis were to assess the retention of plastic pollution by seals and the transport and excretion of microplastic pollution by seabirds. Certain species of seabirds have been reported to ingest and retain plastics in their gastrointestinal tracts, however, far less is known about the ingestion and accumulation of plastics by Arctic mammals. Moreover, even though northern fulmars have been reported to excrete microplastics in their guano (Provencher et al., 2018), how seabirds may be acting as vectors of plastic pollution in the Arctic and to what extent has not yet been extensively researched.

To answer the question of retention of plastic pollution in seals, in Chapter 3, I dissected the stomach contents of 142 seals from four communities in the eastern Canadian Arctic to assess whether the seals that are being harvested by Inuit for subsistence are ingesting and retaining plastics $(>425 \mu \mathrm{m})$ in their stomachs. We found no evidence of accumulated plastics in seal stomachs, suggesting that this culturally and ecologically important animal may currently have limited exposure to plastic pollution in the eastern Canadian Arctic. These results are more representative of ringed seals because they accounted for the largest sample size in the study. More data is needed to confidently comment on the ingestion and retention of plastics by bearded and harbour seals. Our findings are optimistic and provide valuable baseline data for plastic retention in seal stomachs in the Canadian Arctic which can be used to assess future rates of plastic ingestion and retention in seals as the concentration of plastic pollution in the Arctic likely increases. Certainly, as other studies have identified microplastic particles smaller than $425 \mu \mathrm{m}$ in marine mammals (e.g. Hernandez-Milian et al., 2019; Moore et al., 2020), it is 
possible that plastics smaller than $425 \mu \mathrm{m}$ were present in the stomach contents or within prey items (i.e. euphausiids and/or fish). Particles of this size would have likely passed through the seal GITs and been excreted, which is something that has been observed in other studies (e.g. Donohue et al., 2019; Nelms et al., 2018), however, this was outside of the scope of this study. Nonetheless, assessing the passage of plastic particles smaller than $425 \mu \mathrm{m}$ through seal gastrointestinal tracts could be an opportunity for future research that would help further understand the movement of microplastics throughout the environment.

The transport of plastic pollution by seabirds was addressed in Chapter 4, where the faecal precursors (the last approximately $10 \mathrm{~cm}$ of gastrointestinal tract) of northern fulmars and thick-billed murres were inspected for microplastic pollution. The objective of this study was to assess whether seabirds are excreting microplastics via their guano, and if there was a relationship between plastics in the bird gastrointestinal tracts and microplastics in their faecal precursors. I identified microplastic and anthropogenic cellulosic particles in both species of seabirds, however, there was no significant relationship between plastics in the stomachs and microplastics in the faecal precursors of the birds. Our results indicated that seabirds are excreting microplastics to the environment via their guano, however at this time, the use of guano as a standalone method to monitor accumulated plastic in seabirds is not a sufficient replacement for the existing more invasive monitoring methods. Further to quantifying the presence of microplastic particles in seabird faecal precursor samples, I used the data along with estimated excretion frequencies and population surveys (Mallory et al., 2020a) to estimate that fulmars and murres could be depositing up to $3.34 \pm 1.61$ and $45.5 \pm 46.9$ million anthropogenic particles, respectively, per year into the environment during their breeding period at the specific colonies studied. 
This thesis provides not only important information on the interaction with and current threat plastic pollution poses to seals and seabirds in the eastern Canadian Arctic, but it also provides insight into potential monitoring methods of plastic and microplastic pollution in the Arctic. For example, although our study in Chapter 3 found no evidence of plastics larger than $425 \mu \mathrm{m}$ being accumulated in seal stomachs, seals stomachs can be readily available for monitoring given their harvest for subsistence, and it may be worth continuing to dissect and monitor seal stomach contents to establish any trends over a longer period of time. Additionally, monitoring seal stomachs for microplastic pollution could be useful to increase our knowledge on the movement of microplastics throughout environmental systems. Furthermore, the results from Chapter 4 indicated that seabird guano may not be an effective replacement for invasive monitoring techniques in seabirds, however, monitoring environmental concentrations of microplastic pollution around seabird colonies could be useful to establish trends in the accumulation and concentration of microplastics from the marine environment to the terrestrial environment.

Although the research from this thesis provides a glimpse into the interactions that two important animals from the eastern Canadian Arctic currently have with plastic pollution, more work needs to be done to understand the effects and fate of plastic and microplastic pollution in the Arctic. Given that this thesis focused on the eastern Canadian Arctic, more work should be done to further explore the role of plastic pollution throughout other regions of the Canadian Arctic to identify whether the patterns documented in this thesis correspond elsewhere. As Canada continues to collaborate with international partners to address the issue of plastic pollution, finding and establishing an effective monitoring program for plastic pollution in the Arctic is becoming increasingly important (PAME, 2019). From this research, we now know 
that currently, seals in the eastern Canadian Arctic are not likely actively ingesting plastic pollution larger than $425 \mu \mathrm{m}$, yet they may be ingesting smaller particles that would likely be excreted with their faeces. Future work could both continue collecting data on the stomach contents of seals in the Arctic to monitor any changes that may occur over time, as well as expand on the questions of microplastic particles smaller than $425 \mu \mathrm{m}$ in seal GITs by conducting dissections where the stomach contents are chemically digested and inspected for smaller particles. Additionally, the results from Chapter 4 indicated that colonial seabirds such as northern fulmars and thick-billed murres are excreting microplastics via their guano regardless of levels of plastic pollution accumulation in their stomachs. Given the population of seabirds present at breeding colonies every year, seabird guano could represent an important contributor to environmental microplastic concentrations in the Arctic, and as such, research should continue monitoring this input of microplastic pollution to the terrestrial environment, along with expanded research to identify whether environmental concentrations surrounding these colonies can be identified. Since plastic pollution is likely to continue increasing in the Arctic (Cózar et al., 2017), it is crucial to continue monitoring the movement of plastic pollution throughout the Arctic and the interactions this pollution has with Arctic animals. 


\section{References}

Acampora, H., Newton, S., O’Connor, I., 2017. Opportunistic sampling to quantify plastics in the diet of unfledged Black Legged Kittiwakes (Rissa tridactyla), Northern Fulmars (Fulmarus glacialis) and Great Cormorants (Phalacrocorax carbo). Mar. Pollut. Bull. 119, 171-174. https://doi.org/10.1016/j.marpolbul.2017.04.016

Allen, S., Allen, D., Moss, K., Le Roux, G., Phoenix, V.R., Sonke, J.E., 2020. Examination of the ocean as a source for atmospheric microplastics. PLoS One 15, 1-14. https://doi.org/10.1371/journal.pone.0232746

Allen, S., Allen, D., Phoenix, V.R., Le Roux, G., Durántez Jiménez, P., Simonneau, A., Binet, S., Galop, D., 2019. Atmospheric transport and deposition of microplastics in a remote mountain catchment. Nat. Geosci. 12, 339-344. https://doi.org/10.1038/s41561-019-0335-5

Almroth, B.M.C., Åström, L., Roslund, S., Petersson, H., Johansson, M., Persson, N.K., 2018. Quantifying shedding of synthetic fibers from textiles; a source of microplastics released into the environment. Environ. Sci. Pollut. Res. 25, 1191-1199. https://doi.org/10.1007/s11356-017-0528-7

Andrady, A.L., 2011. Microplastics in the marine environment. Mar. Pollut. Bull. 62, 15961605. https://doi.org/10.1016/j.marpolbul.2011.05.030

Andrady, A.L., 2003. Plastics and the Environment. John Wiley \& Sons, Inc., Honoken, New Jersey.

Arthur, C., Baker, J., 2011. Proceedings of the Second Research Workshop on Microplastic Debris. November 5-6, 2010. NOAA Technical Memorandum NOS-OR\&R-39.

Attademo, F.L.N., Balensiefer, D.C., Freire, A.C. da B., de Sousa, G.P., da Cunha, F.A.G.C., Luna, F. de O., 2015. Debris ingestion by the Antillean Manatee (Trichechus manatus manatus). Mar. Pollut. Bull. 101, 284-287. https://doi.org/10.1016/j.marpolbul.2015.09.040

Auman, H.J., Ludwig, J.P., Giesy, J.P., Colborn, T., 1997. Plastic ingestion by Laysan Albatross chicks on Sand Island, Midway Atoll, in 1994 and 1995, in: Robinson, G., Gales, R. (Eds.), Albatross Biology and Conservation. Surrey Beatty \& Sons, Chipping Norton, pp. 239-244.

Avery-Gomm, S., Provencher, J.F., Liboiron, M., Poon, F.E., Smith, P.A., 2018. Plastic pollution in the Labrador Sea: An assessment using the seabird northern fulmar Fulmarus glacialis as a biological monitoring species. Mar. Pollut. Bull. 127, 817-822. https://doi.org/10.1016/j.marpolbul.2017.10.001

Azzarello, M.Y., Van Vleet, E.S., 1987. Marine birds and plastic pollution. Mar. Ecol. Prog. Ser. 37, 295-303. https://doi.org/10.3354/meps037295

Baak, J.E., Provencher, J.F., Mallory, M.L., 2020. Plastic ingestion by four seabird species in the Canadian Arctic: Comparisons across species and time. Mar. Pollut. Bull. 158, 1-8. https://doi.org/10.1016/j.marpolbul.2020.111386

Barnes, D.K.A., Galgani, F., Thompson, R.C., Barlaz, M., Barnes, D.K.A., Galgani, F., Thompson, R.C., Barlaz, M., 2009. Accumulation and Fragmentation of Plastic Debris in Global Environments. Philos. Trans. Biol. Sci. 364, 1985-1998. 
Barrie, L.A., Gregor, D., Hargrave, B., Lake, R., Muir, D., Shearer, R., Tracey, B., Bidleman, T., 1992. Arctic contaminants: sources, occurrence and pathways. Sci. Total Environ. 122, 174. https://doi.org/https://doi-org.proxy.library.carleton.ca/10.1016/0048-9697(92)90245-N

Beck, C.A., Barros, N.B., 1991. The impact of debris on the Florida manatee. Mar. Pollut. Bull. 22, 508-510. https://doi.org/10.1016/0025-326X(91)90406-I

Bergmann, M., Mützel, S., Primpke, S., Tekman, M.B., Trachsel, J., Gerdts, G., 2019. White and wonderful? Microplastics prevail in snow from the Alps to the Arctic. Sci. Adv. 5, 1-11. https://doi.org/DOI: 10.1126/sciadv.aax1157

Bergmann, M., Wirzberger, V., Krumpen, T., Lorenz, C., Primpke, S., Tekman, M.B., Gerdts, G., 2017. High quantities of microplastic in Arctic deep-sea sediments from the HAUSGARTEN Observatory. Environ. Sci. Technol. 51, 11000-11010. https://doi.org/10.1021/acs.est.7b03331

Berrow, S., Ryan, C., O’Brien, J., 2010. Goose barnacle ( Conchoderma auritum ( L .)) attached to tooth of stranded Sowerby' s beaked whale (Mesoplodon bidens Sowerby). Irish Nat. J. $31,136$.

Berrow, S., Massett, N., O’Brien, J., 2007. Humpback Whale Megaptera novaeangliae off Cos Kerry and Galway. Irish Nat. J. 28, 339-340.

Besseling, E., Foekema, E.M., van Franeker, J.A., Leopold, M.F., Kühn, S., Bravo Rebolledo, E.L., Heße, E., Mielke, L., IJzer, J., Kamminga, P., Koelmans, A.A., 2015. Microplastic in a macro filter feeder: Humpback whale Megaptera novaeangliae. Mar. Pollut. Bull. 95, 248252. https://doi.org/10.1016/j.marpolbul.2015.04.007

Birkhead, T.R., Nettleship, D.N., 1987. Ecological relationships between common murres, Uria aalge, and thick-billid murres, Uria lomvia, at the Gannet Islands, Labrador. I.

Morphometrics and timing of breeding. Can. J. Zool. 65, 1621-1629. https://doi.org/10.1139/z87-253

Blais, J.M., Kimpe, L.E., McMahon, D., Keatley, B.E., Mallory, M.L., Douglas, M.S.V., Smol, J.P., 2005. Arctic seabirds transport marine-derived contaminants. Science. 309, 445. https://doi.org/10.1126/science. 1112658

Blais, J.M., Macdonald, R.W., Mackay, D., Webster, E., Harvey, C., Smol, J.P., 2007. Biologically mediated transport of contaminants to aquatic systems. Environ. Sci. Technol. 41, 1075-1084. https://doi.org/10.1021/es061314a

Bond, A.L., Provencher, J.F., Elliot, R.D., Ryan, P.C., Rowe, S., Jones, I.L., Robertson, G.J., Wilhelm, S.I., 2013. Ingestion of plastic marine debris by Common and Thick-billed Murres in the northwestern Atlantic from 1985 to 2012. Mar. Pollut. Bull. 77, 192-195. https://doi.org/10.1016/j.marpolbul.2013.10.005

Bourdages, M.P.T., Provencher, J.F., Sudlovenick, E., Ferguson, S.H., Young, B.G., Pelletier, N., Murphy, M.J.J., D’Addario, A., Vermaire, J.C., 2020. No plastics detected in seal (Phocidae) stomachs harvested in the eastern Canadian Arctic. Mar. Pollut. Bull. 150, 1-5. https://doi.org/10.1016/j.marpolbul.2019.110772

Bradstreet, M.S.W., 1980. Thick-billed murres and black guillemots in the Barrow Strait area, 
N.W.T., during spring: diets and food availability along ice edges. Can. J. Zool. 58, 21202140. https://doi.org/10.1139/z80-292

Bråte, I.L.N., Eidsvoll, D.P., Steindal, C.C., Thomas, K. V., 2016. Plastic ingestion by Atlantic cod (Gadus morhua) from the Norwegian coast. Mar. Pollut. Bull. 112, 105-110. https://doi.org/10.1016/j.marpolbul.2016.08.034

Bravo Rebolledo, E.L., Van Franeker, J.A., Jansen, O.E., Brasseur, S.M.J.M., 2013. Plastic ingestion by harbour seals (Phoca vitulina) in The Netherlands. Mar. Pollut. Bull. 67, 200202. https://doi.org/10.1016/j.marpolbul.2012.11.035

Brimble, S.K., Blais, J.M., Kimpe, L.E., Mallory, M.L., Keatley, B.E., Douglas, M.S.V., Smol, J.P., 2009. Bioenrichment of trace elements in a series of ponds near a northern fulmar (Fulmarus glacialis) colony at Cape Vera, Devon Island. Can. J. Fish. Aquat. Sci. 66, 949958. https://doi.org/10.1139/F09-053

Browne, M.A., Dissanayake, A., Galloway, T.S., Lowe, D.M., Thompson, R.C., 2008. Ingested microscopic plastic translocates to the circulatory system of the mussel, Mytilus edulis (L.). Environ. Sci. Technol. 42, 5026-5031. https://doi.org/10.1021/es800249a

Browne, M.A., Galloway, T., Thompson, R., 2007. Microplastic - an emerging contaminant of potential concern? Integr. Environ. Assess. Manag. 3, 559-566.

Cai, L., Wang, J., Peng, J., Tan, Z., Zhan, Z., Tan, X., Chen, Q., 2017. Characteristic of microplastics in the atmospheric fallout from Dongguan city, China: preliminary research and first evidence. Environ. Sci. Pollut. Res. 24, 24928-24935. https://doi.org/10.1007/s11356-017-0116-x

Carey, M.J., 2011. Intergenerational transfer of plastic debris by Short-tailed Shearwaters (Ardenna tenuirostris). Emu 111, 229-234. https://doi.org/10.1071/MU10085

Carpenter, E.J., Anderson, S.J., Harvey, G.R., Miklas, H.P., Peck, B.B., 1972. Polystyrene Spherules in Coastal Waters. Science. 178, 749-750.

Carpenter, E.J., Smith, K.L.J., 1972. Plastics on the Sargasso Sea Surface. Science. 175, 12401241.

Catarino, A.I., Macchia, V., Sanderson, W.G., Thompson, R.C., Henry, T.B., 2018. Low levels of microplastics (MP) in wild mussels indicate that MP ingestion by humans is minimal compared to exposure via household fibres fallout during a meal. Environ. Pollut. 237, 675684. https://doi.org/10.1016/j.envpol.2018.02.069

Choy, E.S., Kimpe, L.E., Mallory, M.L., Smol, J.P., Blais, J.M., 2010. Contamination of an arctic terrestrial food web with marine-derived persistent organic pollutants transported by breeding seabirds. Environ. Pollut. 158, 3431-3438.

https://doi.org/10.1016/j.envpol.2010.07.014

Cole, M., Webb, H., Lindeque, P.K., Fileman, E.S., Halsband, C., Galloway, T.S., 2014. Isolation of microplastics in biota-rich seawater samples and marine organisms. Sci. Rep. 4, 1-8. https://doi.org/10.1038/srep04528

Cole, M., Lindeque, P., Fileman, E., Halsband, C., Goodhead, R., Moger, J., Galloway, T.S., 
2013. Microplastic Ingestion by Zooplankton. Environ. Sci. Technol. 47, 6646-6655.

Cole, M., Lindeque, P., Halsband, C., Galloway, T.S., 2011. Microplastics as contaminants in the marine environment: A review. Mar. Pollut. Bull. 62, 2588-2597. https://doi.org/10.1016/j.marpolbul.2011.09.025

Cotham, W.E.J., Bidleman, T.F., 1991. Estimating the atmospheric deposition of organichlorine contaminants to the arctic. Chemosphere 22, 165-188.

Cousin, H.R., Auman, H.J., Alderman, R., Virtue, P., 2015. The frequency of ingested plastic debris and its effects on body condition of Short-tailed Shearwater (Puffinus tenuirostris) pre-fledging chicks in Tasmania, Australia. Emu 115, 6-11. https://doi.org/10.1071/MU13086

Covernton, G.A., Collicutt, B., Gurney-Smith, H., Pearce, C., Dower, J., Ross, P., Dudas, S., 2019. Microplastics in bivalves and their habitat in relation to shellfish aquaculture proximity in coastal British Columbia, Canada. Aquac. Environ. Interact. 11, 357-374. https://doi.org/10.3354/aei00316

Cózar, A., Martí, E., Duarte, C.M., García-de-Lomas, J., van Sebille, E., Ballatore, T.J., Eguíluz, V.M., Ignacio González-Gordillo, J., Pedrotti, M.L., Echevarría, F., Troublè, R., Irigoien, X., 2017. The Arctic Ocean as a dead end for floating plastics in the North Atlantic branch of the Thermohaline Circulation. Sci. Adv. 3, 1-8. https://doi.org/10.1126/sciadv.1600582

Crawford, C.B., Quinn, B., 2017. Microplastic identification techniques, Microplastic Pollutants. https://doi.org/10.1016/b978-0-12-809406-8.00010-4

de Stephanis, R., Giménez, J., Carpinelli, E., Gutierrez-Exposito, C., Cañadas, A., 2013. As main meal for sperm whales: Plastics debris. Mar. Pollut. Bull. 69, 206-214. https://doi.org/10.1016/j.marpolbul.2013.01.033

De Witte, B., Devriese, L., Bekaert, K., Hoffman, S., Vandermeersch, G., Cooreman, K., Robbens, J., 2014. Quality assessment of the blue mussel (Mytilus edulis): Comparison between commercial and wild types. Mar. Pollut. Bull. 85, 146-155. https://doi.org/10.1016/j.marpolbul.2014.06.006

Dehghani, S., Moore, F., Akhbarizadeh, R., 2017. Microplastic pollution in deposited urban dust, Tehran metropolis, Iran. Environ. Sci. Pollut. Res. 24, 20360-20371. https://doi.org/10.1007/s11356-017-9674-1

Denuncio, P., Mandiola, M.A., Pérez Salles, S.B., Machado, R., Ott, P.H., De Oliveira, L.R., Rodriguez, D., 2017. Marine debris ingestion by the South American Fur Seal from the Southwest Atlantic Ocean. Mar. Pollut. Bull. 122, 420-425. https://doi.org/10.1016/j.marpolbul.2017.07.013

Derraik, J.G.B., 2002. The pollution of the marine environment by plastic debris: a review. Mar. Pollut. Bull. 44, 842-852. https://doi.org/https://doi.org/10.1016/S0025-326X(02)00220-5

Dickerman, R.W., Goelet, R.G., 1987. Northern Gannet starvation after swallowing styrofoam. Mar. Pollut. Bull. 18, 293. https://doi.org/10.1016/0025-326X(87)90508-X

Donohue, M.J., Masura, J., Gelatt, T., Ream, R., Baker, J.D., Faulhaber, K., Lerner, D.T., 2019. 
Evaluating exposure of northern fur seals, Callorhinus ursinus, to microplastic pollution through fecal analysis. Mar. Pollut. Bull. 138, 213-221.

https://doi.org/10.1016/j.marpolbul.2018.11.036

Dris, R., Gasperi, J., Mirande, C., Mandin, C., Guerrouache, M., Langlois, V., Tassin, B., 2017. A first overview of textile fibers, including microplastics, in indoor and outdoor environments. Environ. Pollut. 221, 453-458. https://doi.org/10.1016/j.envpol.2016.12.013

Dris, R., Gasperi, J., Rocher, V., Saad, M., Renault, N., Tassin, B., 2015. Microplastic contamination in an urban area: A case study in Greater Paris. Environ. Chem. 12, 592-599. https://doi.org/10.1071/EN14167

Dris, R., Gasperi, J., Saad, M., Mirande, C., Tassin, B., 2016. Synthetic fibers in atmospheric fallout: A source of microplastics in the environment? Mar. Pollut. Bull. 104, 290-293. https://doi.org/10.1016/j.marpolbul.2016.01.006

Duis, K., Coors, A., 2016. Microplastics in the aquatic and terrestrial environment: sources (with a specific focus on personal care products), fate and effects. Environ. Sci. Eur. 28, 1-25. https://doi.org/10.1186/s12302-015-0069-y

Environment and Climate Change Canada (ECCC), 2020. Draft Science Assessment of Plastic Pollution. Retrieved from: https://www.canada.ca/en/environment-climatechange/services/evaluating-existing-substances/draft-science-assessment-plasticpollution.html

Environment and Climate Change Canada (ECCC), 2019. Canada's Plastics Science Agenda. Retrieved from: https://www.canada.ca/en/environment-climate-change/services/sciencetechnology.html

Eriksen, M., Lebreton, L.C.M., Carson, H.S., Thiel, M., Moore, C.J., Borerro, J.C., Galgani, F., Ryan, P.G., Reisser, J., 2014. Plastic Pollution in the World's Oceans: More than 5 Trillion Plastic Pieces Weighing over 250,000 Tons Afloat at Sea. PLoS One 9, 1-15. https://doi.org/10.1371/journal.pone.0111913

Eriksson, C., Burton, H., 2003. Origins and Biological Accumulation of Small Plastic Particles in Fur Seals from Macquarie Island. AMBIO A J. Hum. Environ. 32, 380-384. https://doi.org/10.1579/0044-7447-32.6.380

Fendall, L.S., Sewell, M.A., 2009. Contributing to marine pollution by washing your face: Microplastics in facial cleansers. Mar. Pollut. Bull. 58, 1225-1228. https://doi.org/10.1016/j.marpolbul.2009.04.025

Filella, M., 2015. Questions of size and numbers in environmental research on microplastics: methodological and conceptual aspects. Environ. Chem. 12, 527. https://doi.org/10.1071/en15012

Foekema, E.M., De Gruijter, C., Mergia, M.T., Van Franeker, J.A., Murk, A.J., Koelmans, A.A., 2013. Plastic in north sea fish. Environ. Sci. Technol. 47, 8818-8824. https://doi.org/10.1021/es400931b

Free, C.M., Jensen, O.P., Mason, S.A., Eriksen, M., Williamson, N.J., Boldgiv, B., 2014. Highlevels of microplastic pollution in a large, remote, mountain lake. Mar. Pollut. Bull. 85, 
156-163. https://doi.org/10.1016/j.marpolbul.2014.06.001

Fry, D.M., Fefer, S.I., Sileo, L., 1987. Ingestion of plastic debris by Laysan Albatrosses and Wedge-tailed Shearwaters in the Hawaiian Islands. Mar. Pollut. Bull. 18, 339-343. https://doi.org/10.1016/S0025-326X(87)80022-X

Gall, S.C., Thompson, R.C., 2015. The impact of debris on marine life. Mar. Pollut. Bull. 92, 170-179. https://doi.org/10.1016/j.marpolbul.2014.12.041

Gassner, I., Rogan, E., Bruton, T., 2005. A Live Stranding of True's Beaked Whale Mesoplodon mirus True. Irish Nat. J. 28, 170.

Gaston, A.J., Hipfner, J.M., 2020. Thick-billed Murre (Uria lomvia) [WWW Document]. Cornell Lab Ornithol. URL https://doi-org.proxy.library.carleton.ca/10.2173/bow.thbmur.01 (accessed 6.22.20).

Gaston, A.J., Elliott, K.H., Ropert-Coudert, Y., Kato, A., Macdonald, C.A., Mallory, M.L., Gilchrist, H.G., 2013. Modeling foraging range for breeding colonies of thick-billed murres Uria lomvia in the Eastern Canadian Arctic and potential overlap with industrial development. Biol. Conserv. 168, 134-143. https://doi.org/10.1016/j.biocon.2013.09.018

Gaston, A.J., Mallory, M.L., Gilchrist, H.G., 2012. Populations and trends of Canadian Arctic seabirds. Polar Biol. 35, 1221-1232. https://doi.org/10.1007/s00300-012-1168-5

Gaston, A.J., Mallory, M.L., Gilchrist, H.G., O’Donovan, K., 2006. Status, trends and attendance patterns of the northern fulmar Fulmarus glacialis in Nunavut, Canada. Arctic 59, 165-178. https://doi.org/10.14430/arctic339

GESAMP, 2015. Sources, fate and effects of microplastics in the marine environment: a global assessment. (Kershaw, P. J., ed.). (IMO/FAO/UNESCOIOC/UNIDO/WMO/IAEA/UN/UNEP/UNDP Joint Group of Experts on the Scientific Aspects of Marine Environmental Protection). Rep. Stud. GESAMP No. 90, 96 p.

Geyer, R., Jambeck, J.R., Law, K.L., 2017. Production, use, and fate of all plastics ever made. Sci. Adv. 3, 25-29.

Gies, E.A., LeNoble, J.L., Noël, M., Etemadifar, A., Bishay, F., Hall, E.R., Ross, P.S., 2018. Retention of microplastics in a major secondary wastewater treatment plant in Vancouver, Canada. Mar. Pollut. Bull. 133, 553-561. https://doi.org/10.1016/j.marpolbul.2018.06.006

Gil-Delgado, J.A., Guijarro, D., Gosálvez, R.U., López-Iborra, G.M., Ponz, A., Velasco, A., 2017. Presence of plastic particles in waterbirds faeces collected in Spanish lakes. Environ. Pollut. 220, 732-736. https://doi.org/10.1016/j.envpol.2016.09.054

Gjertz, I., Lydersen, C., 1986. The ringed seal (Phoca hispida) spring diet in northwestern Spitsbergen, Svalbard. Polar Res. 4, 53-56. https://doi.org/10.1111/j.17518369.1986.tb00518.x

Gregory, M.R., 1996. Plastic 'Scrubbers' in Hand Cleansers: a Further (and Minor) Source for Marine Pollution Identified. Mar. Pollut. Bull. 32, 867-871.

Gudger, E.W., Hoffmann, W.H., 1931. A Shark Encircled with a Rubber Automobile Tire. Sci. 
Mon. 33, 275-277.

Habib, D., Locke, D.C., Cannone, L.J., 1998. Synthetic fibers as indicators of municipal sewage. Water, Air Soil Pollut. 103, 1-8.

Halsband, C., Herzke, D., 2019. Plastic litter in the European Arctic: What do we know? Emerg. Contam. 5, 308-318. https://doi.org/10.1016/j.emcon.2019.11.001

Hardesty, B.D., Holdsworth, D., Revill, A.T., Wilcox, C., 2015. A biochemical approach for identifying plastics exposure in live wildlife. Methods Ecol. Evol. 6, 92-98.

https://doi.org/10.1111/2041-210X.12277

Hargan, K.E., Michelutti, N., Coleman, K., Grooms, C., Blais, J.M., Kimpe, L.E., Gilchrist, G., Mallory, M., Smol, J.P., 2017. Cliff-nesting seabirds influence production and sediment chemistry of lakes situated above their colony. Sci. Total Environ. 576, 85-98. https://doi.org/10.1016/j.scitotenv.2016.10.024

Hartmann, N.B., Hüffer, T., Thompson, R.C., Hassellöv, M., Verschoor, A., Daugaard, A.E., Rist, S., Karlsson, T., Brennholt, N., Cole, M., Herrling, M.P., Hess, M.C., Ivleva, N.P., Lusher, A.L., Wagner, M., 2019. Are We Speaking the Same Language? Recommendations for a Definition and Categorization Framework for Plastic Debris. Environ. Sci. Technol. 53, 1039-1047. https://doi.org/10.1021/acs.est.8b05297

Helm, P.A., 2017. Improving microplastics source apportionment: a role for microplastic morphology and taxonomy? Anal. Methods 9, 1328-1331. https://doi.org/10.1039/C7AY90016C

Hernandez-Milian, G., Lusher, A., MacGabban, S., Rogan, E., 2019. Microplastics in grey seal (Halichoerus grypus) intestines: Are they associated with parasite aggregations? Mar. Pollut. Bull. 146, 349-354. https://doi.org/10.1016/j.marpolbul.2019.06.014

Hilton, G.M., Furness, R.W., Houston, D.C., 2000. A comparative study of digestion in North Atlantic seabirds. J. Avian Biol. 31, 36-46.

Holst, M., Stirling, I., Hobson, K.A., 2001. Diet of ringed seals (Phoca hispida) on the east and west sides of the North Water Polynya, northern Baffin Bay. Mar. Mammal Sci. 17, 888908. https://doi.org/10.1111/j.1748-7692.2001.tb01304.x

Horton, A.A., Dixon, S.J., 2017. Microplastics: An introduction to environmental transport processes. Wiley Interdiscip. Rev. Water 5, e1268. https://doi.org/10.1002/wat2.1268

Houde, M., Wang, X., Ferguson, S.H., Gagnon, P., Brown, T.M., Tanabe, S., Kunito, T., Kwan, M., Muir, D.C.G., 2017. Spatial and temporal trends of alternative flame retardants and polybrominated diphenyl ethers in ringed seals (Phoca hispida) across the Canadian Arctic. Environ. Pollut. 223, 266-276. https://doi.org/10.1016/j.envpol.2017.01.023

Huntington, A., Corcoran, P.L., Jantunen, L.M., Thaysen, C., Bernstein, S., Stern, G.A., Rochman, C.M., 2020. A first assessment of microplastics and other anthropogenic particles in Hudson Bay and the surrounding Eastern Canadian Arctic waters of Nunavut. Facets 5, 432-454. https://doi.org/10.1139/facets-2019-0042

Hurley, R.R., Lusher, A.L., Olsen, M., Nizzetto, L., 2018. Validation of a Method for Extracting 
Microplastics from Complex, Organic-Rich, Environmental Matrices. Environ. Sci.

Technol. 52, 7409-7417. https://doi.org/10.1021/acs.est.8b01517

Jambeck, J.R., Geyer, R., Wilcox, C., Siegler, T.R., Perryman, M., Andrady, A., Narayan, R., Law, K.L., 2015. Plastic waste inputs from land into the ocean. Science. 347, 768-771. https://doi.org/10.1126/science. 1260352

Karlsson, T.M., Arneborg, L., Broström, G., Almroth, B.C., Gipperth, L., Hassellöv, M., 2018. The unaccountability case of plastic pellet pollution. Mar. Pollut. Bull. 129, 52-60. https://doi.org/10.1016/j.marpolbul.2018.01.041

Koelmans, A.A., Mohamed Nor, H.N., Hermsen, E., Kooi, M., Mintenig, S.M., De France, J., 2019. Microplastics in Freshwaters and Drinking Water: Critical Review and Assessment of Data Quality. Water Res. 155, 410-422. https://doi.org/https://doi.org/10.1016/j.watres.2019.02.054

Kole, P.J., Löhr, A.J., Van Belleghem, F.G.A.J., Ragas, A.M.J., 2017. Wear and tear of tyres: A stealthy source of microplastics in the environment. Int. J. Environ. Res. Public Health 14. https://doi.org/10.3390/ijerph14101265

Kühn, S., Bravo Rebolledo, E.L., van Franeker, J.A., 2015. Deleterious effects of litter on marine life, in: Bergmann, M., Gutow, L., Klages, M. (Eds.), Marine Anthropogenic Litter. Springer International Publishing, pp. 75-116. https://doi.org/10.1007/978-3-319-16510344

Kühn, S., Schaafsma, F.L., Werven, B. Van, Flores, H., Bergmann, M., Egelkraut-Holtus, M., Tekman, M.B., Van Franeker, J.A., 2018. Plastic ingestion by juvenile polar cod (Boreogadus saida) in the Arctic Ocean. Polar Biol. 41, 1269-1278. https://doi.org/10.1007/s00300-018-2283-8

Kühn, S., Werven, B. Van, Oyen, A. Van, Meijboom, A., Bravo, E.L., van Franeker, J.A., 2017. The use of potassium hydroxide $(\mathrm{KOH})$ solution as a suitable approach to isolate plastics ingested by marine organisms. Mar. Pollut. Bull. 115, 86-90. https://doi.org/10.1016/j.marpolbul.2016.11.034

Labansen, A.L., Lydersen, C., Haug, T., Kovacs, K.M., 2007. Spring diet of ringed seals (Phoca hispida) from northwestern Spitsbergen, Norway. ICES J. Mar. Sci. 64, 1246-1256. https://doi.org/10.1093/icesjms/fsm090

Laist, D.W., 1997. Impacts of marine debris: Entanglement of marine life in marine debris including a comprehensive list of species with entanglement and ingestion records, in: Coe, J.M., Rogers, D.B. (Eds.), Marine Debris: Sources, Impacts, and Solutions. Springer Series on Environmental Management, New York, pp. 99-139.

Lavers, J.L., Bond, A.L., Hutton, I., 2014. Plastic ingestion by flesh-footed shearwaters (Puffinus carneipes): Implications for fledgling body condition and the accumulation of plasticderived chemicals. Environ. Pollut. 187, 124-129. https://doi.org/10.1016/j.envpol.2013.12.020

Lechner, A., Keckeis, H., Lumesberger-Loisl, F., Zens, B., Krusch, R., Tritthart, M., Glas, M., Schludermann, E., 2014. The Danube so colourful: A potpourri of plastic litter outnumbers 
fish larvae in Europe's second largest river. Environ. Pollut. 188, 177-181.

https://doi.org/10.1016/j.envpol.2014.02.006

Lenz, R., Enders, K., Stedmon, C.A., MacKenzie, D.M.A., Nielsen, T.G., 2015. A critical assessment of visual identification of marine microplastic using Raman spectroscopy for analysis improvement. Mar. Pollut. Bull. 100, 82-91.

https://doi.org/10.1016/j.marpolbul.2015.09.026

Leslie, H.A., Brandsma, S.H., van Velzen, M.J.M., Vethaak, A.D., 2017. Microplastics en route: Field measurements in the Dutch river delta and Amsterdam canals, wastewater treatment plants, North Sea sediments and biota. Environ. Int. 101, 133-142. https://doi.org/10.1016/j.envint.2017.01.018

Leslie, H.A., 2014. Review of Microplastics in Cosmetics: Scientific background on a potential source of plastic particulate marine litter to support decision-making. VU, Amsterdam. 33 p.

Li, J., Lusher, A.L., Rotchell, J.M., Deudero, S., Turra, A., Bråte, I.L.N., Sun, C., Shahadat Hossain, M., Li, Q., Kolandhasamy, P., Shi, H., 2019. Using mussel as a global bioindicator of coastal microplastic pollution. Environ. Pollut. 244, 522-533.

https://doi.org/10.1016/j.envpol.2018.10.032

Liang, X., Li, J., Martyniuk, C.J., Wang, J., Mao, Y., Lu, H., Zha, J., 2017. Benzotriazole ultraviolet stabilizers alter the expression of the thyroid hormone pathway in zebrafish (Danio rerio) embryos. Chemosphere 182, 22-30. https://doi.org/10.1016/j.chemosphere.2017.05.015

Liboiron, F., Ammendolia, J., Saturno, J., Melvin, J., Zahara, A., Richárd, N., Liboiron, M., 2018. A zero percent plastic ingestion rate by silver hake (Merluccius bilinearis) from the south coast of Newfoundland, Canada. Mar. Pollut. Bull. 131, 267-275. https://doi.org/10.1016/j.marpolbul.2018.04.007

Lobelle, D., Cunliffe, M., 2011. Early microbial biofilm formation on marine plastic debris. Mar. Pollut. Bull. 62, 197-200. https://doi.org/10.1016/j.marpolbul.2010.10.013

Löder, M.G.J., Gerdts, G., 2015. Methodology Used for the Detection and Identification of Microplastics — A Critical Appraisal. https://doi.org/10.1007/978-3-319-16510-3

Lu, Z., De Silva, A.O., Provencher, J.F., Mallory, M.L., Kirk, J.L., Houde, M., Stewart, C., Braune, B.M., Avery-Gomm, S., Muir, D.C.G., 2019. Occurrence of substituted diphenylamine antioxidants and benzotriazole UV stabilizers in Arctic seabirds and seals. Sci. Total Environ. 663, 950-957. https://doi.org/10.1016/j.scitotenv.2019.01.354

Lusher, A.L., Hernandez-Milian, G., Berrow, S., Rogan, E., O’Connor, I., 2018. Incidence of marine debris in cetaceans stranded and bycaught in Ireland: Recent findings and a review of historical knowledge. Environ. Pollut. 232, 467-476. https://doi.org/10.1016/j.envpol.2017.09.070

Lusher, A.L., Welden, N.A., Sobral, P., Cole, M., 2017. Sampling, isolating and identifying microplastics ingested by fish and invertebrates. Anal. Methods 9, 1346-1360. https://doi.org/10.1039/c6ay02415g

Lusher, A.L., Hernandez-Milian, G., O’Brien, J., Berrow, S., O’Connor, I., Officer, R., $2015 a$. 
Microplastic and macroplastic ingestion by a deep diving, oceanic cetacean: The True's beaked whale Mesoplodon mirus. Environ. Pollut. 199, 185-191. https://doi.org/10.1016/j.envpol.2015.01.023

Lusher, A.L., Tirelli, V., O'Connor, I., Officer, R., 2015b. Microplastics in Arctic polar waters: The first reported values of particles in surface and sub-surface samples. Sci. Rep. 5, 1-9. https://doi.org/10.1038/srep14947

Macdonald, R.W., Bewers, J.M., 1996. Contaminants in the arctic marine environment: priorities for protection. ICES J. Mar. Sci. 53, 537-563.

Mahon, A.M., O’Connell, B., Healy, M.G., O’Connor, I., Officer, R., Nash, R., Morrison, L., 2017. Microplastics in Sewage Sludge: Effects of Treatment. Environ. Sci. Technol. 51, 810-818. https://doi.org/10.1021/acs.est.6b04048

Mallory, M.L., Dey, C.J., McIntyre, J., Pratte, I., Mallory, C.L., Francis, C.M., Black, A.L., Geoffroy, C., Dickson, R., Provencher, J.F., 2020a. Long-term declines in the size of Northern Fulmar (Fulmarus glacialis) colonies on Eastern Baffin Island, Canada. Arctic 73, 187-194. https://doi.org/10.14430/arctic70290

Mallory, M.L., Hatch, S.A., Nettleship, D.N., 2020b. Northern Fulmar (Fulmarus glacialis) [WWW Document]. Cornell Lab Ornithol. URL http://bna.birds.cornell.edu/bna/species/361; doi: 10.2173/bna.361 (accessed 6.22.20).

Mallory, M.L., Gaston, A.J., Provencher, J.F., Wong, S.N.P., Anderson, C., Elliott, K.H., Gilchrist, H.G., Janssen, M., Lazarus, T., Patterson, A., Pirie-Dominix, L., Spencer, N.C., 2019. Identifying key marine habitat sites for seabirds and sea ducks in the Canadian Arctic. Environ. Rev. 27, 215-240. https://doi.org/10.1139/er-2018-0067

Mallory, M.L., 2009. Incubation scheduling by Northern Fulmars (Fulmarus glacialis) in the Canadian High Arctic. J. Ornithol. 150, 175-181. https://doi.org/10.1007/s10336-008-03328

Mason, S.A., Garneau, D., Sutton, R., Chu, Y., Ehmann, K., Barnes, J., Fink, P., Papazissimos, D., Rogers, D.L., 2016. Microplastic pollution is widely detected in US municipal wastewater treatment plant effluent. Environ. Pollut. 218, 1045-1054. https://doi.org/10.1016/j.envpol.2016.08.056

McMahon, C.R., Holley, D., Robinson, S., 1999. The diet of itinerant male Hooker's sea lions, Phocarctos hookeri, at sub-Antarctic Macquarie Island. Wildl. Res. 26, 839-846. https://doi.org/10.1071/WR98079

Michelutti, N., Keatley, B.E., Brimble, S., Blais, J.M., Liu, H., Douglas, M.S.V., Mallory, M.L., MacDonald, R.W., Smol, J.P., 2009. Seabird-driven shifts in Arctic pond ecosystems. Proc. R. Soc. B Biol. Sci. 276, 591-596. https://doi.org/10.1098/rspb.2008.1103

Miller, M.E., Kroon, F.J., Motti, C.A., 2017. Recovering microplastics from marine samples: A review of current practices. Mar. Pollut. Bull. 123, 6-18. https://doi.org/10.1016/j.marpolbul.2017.08.058

Moore, C.J., Moore, S.L., Leecaster, M.K., Weisberg, S.B., 2001. A Comparison of Plastic and Plankton in the North Pacific Central Gyre. Mar. Pollut. Bull. 42, 1297-1300. 
Moore, R.C., Loseto, L., Noel, M., Etemadifar, A., Brewster, J.D., MacPhee, S., Bendell, L., Ross, P.S., 2020. Microplastics in beluga whales (Delphinapterus leucas) from the Eastern Beaufort Sea. Mar. Pollut. Bull. 150, 1-7. https://doi.org/10.1016/j.marpolbul.2019.110723

Morgana, S., Ghigliotti, L., Estévez-Calvar, N., Stifanese, R., Wieckzorek, A., Doyle, T., Christiansen, J.S., Faimali, M., Garaventa, F., 2018. Microplastics in the Arctic: A case study with sub-surface water and fish samples off Northeast Greenland. Environ. Pollut. 242, 1078-1086. https://doi.org/10.1016/j.envpol.2018.08.001

Moser, M.L., Lee, D.S., 1992. A Fourteen-Year Survey of Plastic Ingestion by Western North Atlantic Seabirds. Colon. Waterbirds 15, 83-94. https://doi.org/10.2307/1521357

Munno, K., De Frond, H., O’donnell, B., Rochman, C.M., 2020. Increasing the accessibility for characterizing microplastics: Introducing new application-based and spectral libraries of plastic particles (SLoPP and SLoPP-E). Anal. Chem. 92, 2443-2451.

https://doi.org/10.1021/acs.analchem.9b03626

Murphy, F., Ewins, C., Carbonnier, F., Quinn, B., 2016. Wastewater Treatment Works (WwTW) as a source of microplastics in the aquatic environment. Environ. Sci. Technol. 50, 58005808. https://doi.org/10.1021/acs.est.5b05416

Nelms, S.E., Barnett, J., Brownlow, A., Davison, N.J., Deaville, R., Galloway, T.S., Lindeque, P.K., Santillo, D., Godley, B.J., 2019. Microplastics in marine mammals stranded around the British coast: ubiquitous but transitory? Sci. Rep. 9, 1-8. https://doi.org/10.1038/s41598-018-37428-3

Nelms, S.E., Galloway, T.S., Godley, B.J., Jarvis, D.S., Lindeque, P.K., 2018. Investigating microplastic trophic transfer in marine top predators. Environ. Pollut. 238, 999-1007. https://doi.org/10.1016/j.envpol.2018.02.016

Nielsen, J., Hedeholm, R.B., Simon, M., Steffensen, J.F., 2014. Distribution and feeding ecology of the Greenland shark (Somniosus microcephalus) in Greenland waters. Polar Biol. 37, 37 46. https://doi.org/10.1007/s00300-013-1408-3

O’Hanlon, N.J., James, N.A., Masden, E.A., Bond, A.L., 2017. Seabirds and marine plastic debris in the northeastern Atlantic: A synthesis and recommendations for monitoring and research. Environ. Pollut. 231, 1291-1301. https://doi.org/10.1016/j.envpol.2017.08.101

Obbard, R.W., 2018. Microplastics in Polar Regions: The role of long range transport. Curr. Opin. Environ. Sci. Heal. 1, 24-29. https://doi.org/10.1016/j.coesh.2017.10.004

Obbard, R.W., Sadri, S., Wong, Y.Q., Khitun, A.A., Baker, I., Thompson, R.C., 2014. Global warming releases microplastic legacy frozen in Arctic Sea ice. AGU Earth's Futur. 315320. https://doi.org/10.1002/2014EF000240.Abstract

Ogloff, W.R., Yurkowski, D.J., Davoren, G.K., Ferguson, S.H., 2019. Diet and isotopic niche overlap elucidate competition potential between seasonally sympatric phocids in the Canadian Arctic. Mar. Biol. 166, 1-12. https://doi.org/10.1007/s00227-019-3549-6

Panti, C., Baini, M., Lusher, A., Hernandez-Milan, G., Bravo Rebolledo, E.L., Unger, B., Syberg, K., Simmonds, M.P., Fossi, M.C., 2019. Marine litter: One of the major threats for marine mammals. Outcomes from the European Cetacean Society workshop. Environ. 
Pollut. 247, 72-79. https://doi.org/10.1016/j.envpol.2019.01.029

Peeken, I., Primpke, S., Beyer, B., Gütermann, J., Katlein, C., Krumpen, T., Bergmann, M., Hehemann, L., Gerdts, G., 2018. Arctic sea ice is an important temporal sink and means of transport for microplastic. Nat. Commun. 9. https://doi.org/10.1038/s41467-018-03825-5

Perez-Venegas, D.J., Seguel, M., Pavés, H., Pulgar, J., Urbina, M., Ahrendt, C., GalbánMalagón, C., 2018. First detection of plastic microfibers in a wild population of South American fur seals (Arctocephalus australis) in the Chilean Northern Patagonia. Mar. Pollut. Bull. 136, 50-54. https://doi.org/10.1016/j.marpolbul.2018.08.065

Pettit, T.N., Grant, G.S., Whittow, G.C., 1981. Ingestion of Plastics by Laysan Albatross. Auk 98, 839-841. https://doi.org/https://doi.org/10.1093/auk/98.4.839a

Pierce, K.E., Harris, R.J., Larned, L.S., Pokras, M.A., 2004. Obstruction and starvation associated with plastic ingestion in a Northern Gannet Morus bassanus and a Greater Shearwater Puffinus gravis. Mar. Ornithol. 32, 187-189.

PlasticsEurope, 2019. Plastics - the Facts 2019: An analysis of European plastics production, demand and waste data. Retrieved from https://www.plasticseurope.org/

PlasticsEurope, 2008. The Compelling Facts About Plastics: An analysis of plastics production, demand and recovery for 2006 in Europe. https://www.plasticseurope.org/

Poon, F.E., Provencher, J.F., Mallory, M.L., Braune, B.M., Smith, P.A., 2017. Levels of ingested debris vary across species in Canadian Arctic seabirds. Mar. Pollut. Bull. 116, 517-520. https://doi.org/10.1016/j.marpolbul.2016.11.051

Primpke, S., Wirth, M., Lorenz, C., Gerdts, G., 2018. Reference database design for the automated analysis of microplastic samples based on Fourier transform infrared (FTIR) spectroscopy. Anal. Bioanal. Chem. 410, 5131-5141. https://doi.org/10.1007/s00216-018$1156-\mathrm{x}$

Protection of the Arctic Marine Environment (PAME), 2019. Desktop study on marine litter including microplastics in the Arctic.

Provencher, J.F., Avery-Gomm, S., Braune, B.M., Letcher, R.J., Dey, C.J., Mallory, M.L., 2020a. Are phthalate ester contaminants in northern fulmar preen oil higher in birds that have ingested more plastic? Mar. Pollut. Bull. 150, 110679. https://doi.org/10.1016/j.marpolbul.2019.110679

Provencher, J.F., Liboiron, M., Borrelle, S.B., Bond, A.L., Rochman, C., Lavers, J.L., AveryGomm, S., Yamashita, R., Ryan, P.G., Lusher, A.L., Hammer, S., Bradshaw, H., Khan, J., Mallory, M.L., 2020b. A Horizon Scan of research priorities to inform policies aimed at reducing the harm of plastic pollution to biota. Sci. Total Environ. 139381. https://doi.org/10.1016/j.scitotenv.2020.139381

Provencher, J.F., Ammendolia, J., Rochman, C.M., Mallory, M.L., 2019. Assessing plastic debris in aquatic food webs: What we know and don't know about uptake and trophic transfer. Environ. Rev. 27, 304-317. https://doi.org/10.1139/er-2018-0079

Provencher, J.F., Vermaire, J.C., Avery-Gomm, S., Braune, B.M., Mallory, M.L., 2018. Garbage 
in guano? Microplastic debris found in faecal precursors of seabirds known to ingest

plastics. Sci. Total Environ. 644, 1477-1484.

https://doi.org/10.1016/j.scitotenv.2018.07.101

Provencher, J.F., Bond, A.L., Avery-Gomm, S., Borrelle, S.B., Bravo Rebolledo, E.L., Hammer, S., Kühn, S., Lavers, J.L., Mallory, M.L., Trevail, A., van Franeker, J.A., 2017. Quantifying ingested debris in marine megafauna: a review and recommendations for standardization. Anal. Methods 9, 1454-1469. https://doi.org/10.1039/c6ay02419j

Provencher, J.F., Bond, A.L., Mallory, M.L., 2015. Marine birds and plastic debris in Canada: a national synthesis and a way forward. Environ. Rev. 13, 1-13. https://doi.org/10.1139/er2014-0039

Provencher, J.F., Bond, A.L., Hedd, A., Montevecchi, W.A., Muzaffar, S.B., Courchesne, S.J., Gilchrist, H.G., Jamieson, S.E., Merkel, F.R., Falk, K., Durinck, J., Mallory, M.L., 2014. Prevalence of marine debris in marine birds from the North Atlantic. Mar. Pollut. Bull. 84, 411-417. https://doi.org/10.1016/j.marpolbul.2014.04.044

Provencher, J.F., McEwan, M., Mallory, M.L., Braune, B.M., Carpenter, J., Harms, N.J., Savard, G., Gilchrist, H.G., 2013. How wildlife research can be used to promote wider community participation in the north. Arctic 66, 237-243.

https://doi.org/https://doi.org/10.14430/arctic4302

Provencher, J.F., Gaston, A.J., Mallory, M.L., O'hara, P.D., Gilchrist, H.G., 2010. Ingested plastic in a diving seabird, the thick-billed murre (Uria lomvia), in the eastern Canadian Arctic. Mar. Pollut. Bull. 60, 1406-1411. https://doi.org/10.1016/j.marpolbul.2010.05.017

R Core Team, 2020. R: A language and environment for statistical computing. R Foundation for Statistical Computing, Vienna, Austria. https://www.R-project.org/

Rapp, D.C., Youngren, S.M., Hartzell, P., David Hyrenbach, K., 2017. Community-wide patterns of plastic ingestion in seabirds breeding at French Frigate Shoals, Northwestern Hawaiian Islands. Mar. Pollut. Bull. 123, 269-278. https://doi.org/10.1016/j.marpolbul.2017.08.047

Reynolds, C., Ryan, P.G., 2018. Micro-plastic ingestion by waterbirds from contaminated wetlands in South Africa. Mar. Pollut. Bull. 126, 330-333. https://doi.org/10.1016/j.marpolbul.2017.11.021

Robards, M.D., Piatt, J.F., Wohl, K.D., 1995. Increasing frequency of plastic particles ingested by seabirds in the subarctic North Pacific. Mar. Pollut. Bull. 30, 151-157. https://doi.org/10.1016/0025-326X(94)00121-O

Rocha-Santos, T., Duarte, A.C., 2015. A critical overview of the analytical approaches to the occurrence, the fate and the behavior of microplastics in the environment. Trends Anal. Chem. 65, 47-53. https://doi.org/10.1016/j.trac.2014.10.011

Rochman, C.M., Brookson, C., Bikker, J., Djuric, N., Earn, A., Bucci, K., Athey, S., Huntington, A., McIlwraith, H., Munno, K., De Frond, H., Kolomijeca, A., Erdle, L., Grbic, J., Bayoumi, M., Borrelle, S.B., Wu, T., Santoro, S., Werbowski, L.M., Zhu, X., Giles, R.K., Hamilton, B.M., Thaysen, C., Kaura, A., Klasios, N., Ead, L., Kim, J., Sherlock, C., Ho, A., Hung, C., 2019. Rethinking microplastics as a diverse contaminant suite. Environ. Toxicol. 
Chem. 38, 703-711. https://doi.org/10.1002/etc.4371

Rochman, C.M., Regan, F., Thompson, R.C., 2017. On the harmonization of method for measuring the occurrence, fate and effects of microplastics. Anal. Methods 9, 1324-1325. https://doi.org/10.1039/C7AY90014G

Rodríguez, A., Rodríguez, B., Nazaret Carrasco, M., 2012. High prevalence of parental delivery of plastic debris in Cory's shearwaters (Calonectris diomedea). Mar. Pollut. Bull. 64, 22192223. https://doi.org/10.1016/j.marpolbul.2012.06.011

Rothstein, S.I., 1973. Plastic particle pollution of the surface of the Atlantic Ocean: Evidence from a seabird. Condor 75, 344-345. https://doi.org/10.2307/1366176

Rummel, C.D., Löder, M.G.J., Fricke, N.F., Lang, T., Griebeler, E.M., Janke, M., Gerdts, G., 2016. Plastic ingestion by pelagic and demersal fish from the North Sea and Baltic Sea. Mar. Pollut. Bull. 102, 134-141. https://doi.org/10.1016/j.marpolbul.2015.11.043

Ryan, P.G., de Bruyn, P.J.N., Bester, M.N., 2016. Regional differences in plastic ingestion among Southern Ocean fur seals and albatrosses. Mar. Pollut. Bull. 104, 207-210. https://doi.org/10.1016/j.marpolbul.2016.01.032

Ryan, P.G., Moore, C.J., van Franeker, J.A., Moloney, C.L., 2009. Monitoring the abundance of plastic debris in the marine environment. Philos. Trans. R. Soc. B 364, 1999-2012. https://doi.org/10.1098/rstb.2008.0207

Ryan, P.G., 1988. Effects of ingested plastic on seabird feeding: Evidence from chickens. Mar. Pollut. Bull. 19, 125-128. https://doi.org/10.1016/0025-326X(88)90708-4

Ryan, P.G., Jackson, S., 1986. Stomach Pumping: Is Killing Seabirds Necessary? Auk 103, 427428. https://doi.org/10.1093/auk/103.2.427

Salman, A., Bilecenoglu, M., Güçlüsoy, H., 2001. Stomach contents of two Mediterranean monk seals (Monachus monachus) from the Aegean Sea, Turkey. J. Mar. Biol. Assoc. United Kingdom 81, 719-720. https://doi.org/10.1017/S0025315401004519

Salvador Cesa, F., Turra, A., Baruque-Ramos, J., 2017. Synthetic fibers as microplastics in the marine environment: A review from textile perspective with a focus on domestic washings. Sci. Total Environ. 598, 1116-1129. https://doi.org/10.1016/j.scitotenv.2017.04.172

Schuyler, Q., Hardesty, B.D., Wilcox, C., Townsend, K., 2012. To eat or not to eat? debris selectivity by marine turtles. PLoS One 7, 1-9. https://doi.org/10.1371/journal.pone.0040884

Searles, E.Q., 2019. 'Fresh seal blood looks like beauty and life' \#Sealfies and subsistence in Nunavut. Hunt. Gatherer Res. 3, 677-696. https://doi.org/10.3828/hgr.2017.34

Siegstad, H., Neve, P.B., Heide-Jørgensen, M.P., Härkönen, T., 1998. Diet of the ringed seal (Phoca hispida) in Greenland. NAMMCO Sci. Publ. 1, 229-241. https://doi.org/10.7557/3.2991

Sievert, P.R., Sileo, L., 1993. The effects of ingested plastic on growth and survival of albatross chicks, in: Vermeer, K., Briggs, K.T., Morgan, K.H., Siegel-Causey, D. (Eds.), The Status, 
Ecology and Conservation of Marine Birds of the North Pacific. Canadian Wildlife Service, Environment Canada, Ottawa, pp. 212-217.

Stanton, T., Johnson, M., Nathanail, P., MacNaughtan, W., Gomes, R.L., 2019. Freshwater and airborne textile fibre populations are dominated by 'natural', not microplastic, fibres. Sci. Total Environ. 666, 377-389. https://doi.org/10.1016/j.scitotenv.2019.02.278

Stempniewicz, L., 1990. Biomass of Dovekie excreta in the vicinity of a breeding colony. Colon. Waterbirds 13, 62-66. https://doi.org/10.2307/1521421

Stewart, R.E.A., Stewart, B.E., Stirling, I., Street, E., 1996. Counts of growth layer groups in cementum and dentine in ringed seals (Phoca hispida). Mar. Mammal Sci. 12, 383-401. https://doi.org/10.1111/j.1748-7692.1996.tb00591.x

Talvitie, J., Mikola, A., Koistinen, A., Setala, O., 2017. Solutions to microplastic pollution Removal of microplastics from wastewater effluent with advanced wastewater treatment technologies. Water Res. 123, 401-407. https://doi.org/10.1016/j.watres.2017.07.005

Talvitie, J., Heinonen, M., Pääkkönen, J.P., Vahtera, E., Mikola, A., Setälä, O., Vahala, R., 2015. Do wastewater treatment plants act as a potential point source of microplastics? Preliminary study in the coastal Gulf of Finland, Baltic Sea. Water Sci. Technol. 72, 1495-1504. https://doi.org/10.2166/wst.2015.360

Tanaka, K., Takada, H., Yamashita, R., Mizukawa, K., Fukuwaka, M. aki, Watanuki, Y., 2013. Accumulation of plastic-derived chemicals in tissues of seabirds ingesting marine plastics. Mar. Pollut. Bull. 69, 219-222. https://doi.org/10.1016/j.marpolbul.2012.12.010

Tavares, D.C., de Moura, J.F., Merico, A., Siciliano, S., 2017. Incidence of marine debris in seabirds feeding at different water depths. Mar. Pollut. Bull. 119, 68-73. https://doi.org/10.1016/j.marpolbul.2017.04.012

Tekman, M.B., Krumpen, T., Bergmann, M., 2017. Marine litter on deep Arctic seafloor continues to increase and spreads to the North at the HAUSGARTEN observatory. Deep. Res. Part I Oceanogr. Res. Pap. 120, 88-99. https://doi.org/10.1016/j.dsr.2016.12.011

Teuten, E.L., Saquing, J.M., Knappe, D.R.U., Barlaz, M.A., Jonsson, S., Björn, A., Rowland, S.J., Thompson, R.C., Galloway, T.S., Yamashita, R., Ochi, D., Watanuki, Y., Moore, C., Viet, P.H., Tana, T.S., Prudente, M., Boonyatumanond, R., Zakaria, M.P., Akkhavong, K., Ogata, Y., Hirai, H., Iwasa, S., Mizukawa, K., Hagino, Y., Imamura, A., Saha, M., Takada, H., 2009. Transport and release of chemicals from plastics to the environment and to wildlife. Philos. Trans. R. Soc. B Biol. Sci. 364, 2027-2045. https://doi.org/10.1098/rstb.2008.0284

Thompson, R.C., Moore, C.J., vom Saal, F.S., Swan, S.H., 2009. Plastics, the environment and human health: current consensus and future trends. Philos. Trans. Biol. Sci. 364, 21532166. https://doi.org/10.1098/rstb.2009.0053

Threlfall, W., 1968. The food of three species of gulls in Newfoundland. Can. Field-Naturalist $82,176-180$.

Torre, M., Digka, N., Anastasopoulou, A., Tsangaris, C., Mytilineou, C., 2016. Anthropogenic microfibres pollution in marine biota. A new and simple methodology to minimize airborne 
contamination. Mar. Pollut. Bull. 113, 55-61.

https://doi.org/10.1016/j.marpolbul.2016.07.050

Trevail, A.M., Gabrielsen, G.W., Kühn, S., van Franeker, J.A., 2015. Elevated levels of ingested plastic in a high Arctic seabird, the northern fulmar (Fulmarus glacialis). Polar Biol. 38, 975-981. https://doi.org/10.1007/s00300-015-1657-4

Twiss, M.R., 2016. Standardized methods are required to assess and manage microplastic contamination of the Great Lakes system. J. Great Lakes Res. 42, 921-925. https://doi.org/10.1016/j.jglr.2016.07.032

Unger, B., Herr, H., Benke, H., Böhmert, M., Burkhardt-Holm, P., Dähne, M., Hillmann, M., Wolff-Schmidt, K., Wohlsein, P., Siebert, U., 2017. Marine debris in harbour porpoises and seals from German waters. Mar. Environ. Res. 130, 77-84. https://doi.org/10.1016/j.marenvres.2017.07.009

Van Cauwenberghe, L., Devriese, L., Galgani, F., Robbens, J., Janssen, C.R., 2015. Microplastics in sediments: A review of techniques, occurrence and effects. Mar. Environ. Res. 111, 5-17. https://doi.org/10.1016/j.marenvres.2015.06.007

Van Cauwenberghe, L., Janssen, C.R., 2014. Microplastics in bivalves cultured for human consumption. Environ. Pollut. 193, 65-70. https://doi.org/10.1016/j.envpol.2014.06.010

Van Cauwenberghe, L., Vanreusel, A., Mees, J., Janssen, C.R., 2013. Microplastic pollution in deep-sea sediments. Environ. Pollut. 182, 495-499. https://doi.org/10.1016/j.envpol.2013.08.013

van Franeker, J.A., Bravo Rebolledo, E.L., Hesse, E., Ijsseldijk, L.L., Kühn, S., Leopold, M., Mielke, L., 2018. Plastic ingestion by harbour porpoises Phocoena phocoena in the Netherlands: Establishing a standardised method. Ambio 47, 387-397. https://doi.org/10.1007/s13280-017-1002-y

van Franeker, J.A., Law, K.L., 2015. Seabirds, gyres and global trends in plastic pollution. Environ. Pollut. 203, 89-96. https://doi.org/10.1016/j.envpol.2015.02.034

van Franeker, J.A., Blaize, C., Danielsen, J., Fairclough, K., Gollan, J., Guse, N., Hansen, P., Heubeck, M., Jensen, J., Le, G., Olsen, B., Olsen, K., Pedersen, J., Stienen, E.W.M., Turner, D.M., 2011. Monitoring plastic ingestion by the northern fulmar Fulmarus glacialis in the North Sea. Environ. Pollut. 159, 2609-2615. https://doi.org/10.1016/j.envpol.2011.06.008

van Franeker, J.A., Bell, P.J., 1988. Plastic ingestion by petrels breeding in Antarctica. Mar. Pollut. Bull. 19, 672-674. https://doi.org/10.1016/0025-326X(88)90388-8

van Sebille, E., Chris, W., Laurent, L., Nikolai, M., Britta Denise, H., van Franeker, J.A., Marcus, E., David, S., Francois, G., Law, K.L., 2015. A global inventory of small floating plastic debris. Environ. Res. Lett. 10, 1-11. https://doi.org/10.1088/17489326/10/12/124006

Vassilenko, K., Watkins, M., Chastain, S., Posacka, A., Ross, P.S., 2019. Me, My Clothes and the Ocean: The role of textiles in microfiber pollution. Science Feature. Ocean Wise Conservation Association, Vancouver, Canada, 16 pp. 
Verlis, K.M., Campbell, M.L., Wilson, S.P., 2018. Seabirds and plastics don't mix: Examining the differences in marine plastic ingestion in wedge-tailed shearwater chicks at near-shore and offshore locations. Mar. Pollut. Bull. 135, 852-861.

https://doi.org/10.1016/j.marpolbul.2018.08.016

Verlis, K.M., Campbell, M.L., Wilson, S.P., 2013. Ingestion of marine debris plastic by the wedge-tailed shearwater Ardenna pacifica in the Great Barrier Reef, Australia. Mar. Pollut. Bull. 72, 244-249. https://doi.org/10.1016/j.marpolbul.2013.03.017

Vermaire, J.C., Pomeroy, C., Herczegh, S.M., Haggart, O., Murphy, M., 2017. Microplastic abundance and distribution in the open water and sediment of the Ottawa River, Canada, and its tributaries. Facets 2, 301-314. https://doi.org/10.1139/facets-2016-0070

Zalasiewicz, J., Waters, C.N., Ivar do Sul, J.A., Corcoran, P.L., Barnosky, A.D., Cearreta, A., Edgeworth, M., Gałuszka, A., Jeandel, C., Leinfelder, R., McNeill, J.R., Steffen, W., Summerhayes, C., Wagreich, M., Williams, M., Wolfe, A.P., Yonan, Y., 2016. The geological cycle of plastics and their use as a stratigraphic indicator of the Anthropocene. Anthropocene 13, 4-17. https://doi.org/10.1016/j.ancene.2016.01.002

Zhang, X., Meyer, T., Muir, D.C.G., Teixeira, C., Wang, X., Wania, F., 2013. Atmospheric deposition of current use pesticides in the Arctic: Snow core records from the Devon Island Ice Cap, Nunavut, Canada. Environ. Sci. Process. Impacts 15, 2304-2311. https://doi.org/10.1039/c3em00433c

Ziajahromi, S., Neale, P.A., Rintoul, L., Leusch, F.D.L., 2017. Wastewater treatment plants as a pathway for microplastics: Development of a new approach to sample wastewater-based microplastics. Water Res. 112, 93-99. https://doi.org/10.1016/j.watres.2017.01.042

Zubris, K.A. V., Richards, B.K., 2005. Synthetic fibers as an indicator of land application of sludge. Environ. Pollut. 138, 201-211. https://doi.org/10.1016/j.envpol.2005.04.013 


\section{Appendices}

\section{A. Review of Marine Debris Ingestion by Marine Mammals}

Table 7.1: Summary of a selection of studies reporting on the ingestion of anthropogenic debris by marine mammals.

\begin{tabular}{|c|c|c|c|c|c|c|c|c|c|c|c|}
\hline Taxa & Family & Species & $\begin{array}{l}\text { \# of } \\
\text { specimens }\end{array}$ & $\begin{array}{l}\# \text { of } \\
\text { specimens } \\
\text { with } \\
\text { ingested } \\
\text { debris }\end{array}$ & $\begin{array}{l}\text { Range \# } \\
\text { plastic / } \\
\text { specimen }\end{array}$ & $\begin{array}{l}\text { Total } \\
\# \\
\text { plastic }\end{array}$ & Year & Location & $\begin{array}{l}\text { Sample } \\
\text { type }\end{array}$ & $\begin{array}{l}\text { Plastic } \\
\text { size } \\
\text { class }\end{array}$ & Reference \\
\hline Cetacean & Balaenopteridae & Fin whale & 1 & 1 & $\mathrm{~N} / \mathrm{A}$ & 16 & 2012 & $\begin{array}{l}\text { The } \\
\text { Netherlands }\end{array}$ & GIT & Micro & $\begin{array}{l}\text { Besseling } \\
\text { et al. } \\
(2015)\end{array}$ \\
\hline Cetacean & Balaenopteridae & $\begin{array}{l}\text { Humpback } \\
\text { whale }\end{array}$ & 1 & 1 & N/A & 1 & 2006 & Irish coast & GIT & Macro & $\begin{array}{l}\text { Berrow et } \\
\text { al. (2007) }\end{array}$ \\
\hline Cetacean & Delphinidae & $\begin{array}{l}\text { Atlantic } \\
\text { white-sided } \\
\text { dolphin }\end{array}$ & 1 & 1 & N/A & 8 & 2016 & $\begin{array}{l}\text { United } \\
\text { Kingdom }\end{array}$ & GIT & Micro & $\begin{array}{l}\text { Nelms et } \\
\text { al. (2019) }\end{array}$ \\
\hline Cetacean & Delphinidae & $\begin{array}{l}\text { Bottlenose } \\
\text { dolphin }\end{array}$ & 1 & 1 & N/A & 6 & 2016 & $\begin{array}{l}\text { United } \\
\text { Kingdom }\end{array}$ & GIT & Micro & $\begin{array}{l}\text { Nelms et } \\
\text { al. (2019) }\end{array}$ \\
\hline Cetacean & Delphinidae & $\begin{array}{l}\text { Common } \\
\text { bottlenose } \\
\text { dolphin }\end{array}$ & 147 & $\begin{array}{l}3 \\
10 \\
1\end{array}$ & N/D & $\mathrm{N} / \mathrm{D}$ & $\begin{array}{l}2003- \\
2015\end{array}$ & Irish coast & GIT & $\begin{array}{l}\text { Macro } \\
\text { Micro } \\
\text { Both }\end{array}$ & $\begin{array}{l}\text { Lusher et } \\
\text { al. (2018) }\end{array}$ \\
\hline Cetacean & Delphinidae & $\begin{array}{l}\text { Common } \\
\text { dolphin }\end{array}$ & 16 & 16 & $1-12$ & 111 & $\begin{array}{l}2016- \\
2017\end{array}$ & $\begin{array}{l}\text { United } \\
\text { Kingdom }\end{array}$ & GIT & Micro & $\begin{array}{l}\text { Nelms et } \\
\text { al. (2019) }\end{array}$ \\
\hline Cetacean & Delphinidae & Killer whale & 5 & 1 & $\mathrm{~N} / \mathrm{D}$ & $\mathrm{N} / \mathrm{D}$ & 2001 & Irish coast & GIT & Macro & $\begin{array}{l}\text { Lusher et } \\
\text { al. (2018) }\end{array}$ \\
\hline Cetacean & Delphinidae & $\begin{array}{l}\text { Risso's } \\
\text { dolphin }\end{array}$ & 8 & 2 & $\mathrm{~N} / \mathrm{D}$ & N/D & $\begin{array}{l}1997- \\
2003\end{array}$ & Irish coast & GIT & Macro & $\begin{array}{l}\text { Lusher et } \\
\text { al. (2018) }\end{array}$ \\
\hline Cetacean & Delphinidae & $\begin{array}{l}\text { Risso's } \\
\text { dolphin }\end{array}$ & 1 & 1 & $\mathrm{~N} / \mathrm{A}$ & 9 & 2016 & $\begin{array}{l}\text { United } \\
\text { Kingdom }\end{array}$ & GIT & Micro & $\begin{array}{l}\text { Nelms et } \\
\text { al. (2019) }\end{array}$ \\
\hline Cetacean & Delphinidae & $\begin{array}{l}\text { Short-beaked } \\
\text { common } \\
\text { dolphin }\end{array}$ & 147 & $\begin{array}{l}3 \\
10\end{array}$ & N/D & N/D & $\begin{array}{l}2003- \\
2015\end{array}$ & Irish coast & GIT & $\begin{array}{l}\text { Macro } \\
\text { Micro }\end{array}$ & $\begin{array}{l}\text { Lusher et } \\
\text { al. (2018) }\end{array}$ \\
\hline Cetacean & Delphinidae & $\begin{array}{l}\text { Striped } \\
\text { dolphin }\end{array}$ & 1 & 1 & N/A & 7 & 2015 & $\begin{array}{l}\text { United } \\
\text { Kingdom }\end{array}$ & GIT & Micro & $\begin{array}{l}\text { Nelms et } \\
\text { al. (2019) }\end{array}$ \\
\hline Cetacean & Delphinidae & $\begin{array}{l}\text { White-beaked } \\
\text { dolphin }\end{array}$ & 1 & 1 & N/A & 3 & 2016 & $\begin{array}{l}\text { United } \\
\text { Kingdom }\end{array}$ & GIT & Micro & $\begin{array}{l}\text { Nelms et } \\
\text { al. (2019) }\end{array}$ \\
\hline
\end{tabular}




\begin{tabular}{|c|c|c|c|c|c|c|c|c|c|c|c|}
\hline Cetacean & Kogiidae & $\begin{array}{l}\text { Pygmy sperm } \\
\text { whale }\end{array}$ & 1 & 1 & N/A & 4 & 2011 & $\begin{array}{l}\text { United } \\
\text { Kingdom }\end{array}$ & GIT & Micro & $\begin{array}{l}\text { Nelms et } \\
\text { al. (2019) }\end{array}$ \\
\hline Cetacean & Monodontidae & Beluga whale & 7 & 7 & $18-147$ & 350 & $\begin{array}{l}2017- \\
2018\end{array}$ & $\begin{array}{l}\text { Tuktoyaktuk, } \\
\text { Northwest } \\
\text { Territories, } \\
\text { Canada }\end{array}$ & GIT & Micro & $\begin{array}{l}\text { Moore et } \\
\text { al. }(2020)\end{array}$ \\
\hline Cetacean & Phocoenidae & $\begin{array}{l}\text { Harbour } \\
\text { porpoise }\end{array}$ & 120 & $\begin{array}{l}6 \\
5\end{array}$ & N/D & N/D & $\begin{array}{l}1996- \\
2015\end{array}$ & Irish coast & GIT & $\begin{array}{l}\text { Macro } \\
\text { Micro }\end{array}$ & $\begin{array}{l}\text { Lusher et } \\
\text { al. (2018) }\end{array}$ \\
\hline Cetacean & Phocoenidae & $\begin{array}{l}\text { Harbour } \\
\text { porpoise }\end{array}$ & 21 & 21 & $2-11$ & 110 & $\begin{array}{l}2016- \\
2017\end{array}$ & $\begin{array}{l}\text { United } \\
\text { Kingdom }\end{array}$ & GIT & Micro & $\begin{array}{l}\text { Nelms et } \\
\text { al. (2019) }\end{array}$ \\
\hline Cetacean & Phocoenidae & $\begin{array}{l}\text { Harbour } \\
\text { porpoise }\end{array}$ & 548 & 4 & $1-3$ & 7 & $\begin{array}{l}1990- \\
2014\end{array}$ & $\begin{array}{l}\text { North and } \\
\text { Baltic Seas }\end{array}$ & GIT & Macro & $\begin{array}{l}\text { Unger et } \\
\text { al. }(2017)\end{array}$ \\
\hline Cetacean & Phocoenidae & $\begin{array}{l}\text { Harbour } \\
\text { porpoise }\end{array}$ & 654 & 47 & N/D & 76 & $\begin{array}{l}2003- \\
2007\end{array}$ & Dutch coast & GIT & Micro & $\begin{array}{l}\text { van } \\
\text { Franeker et } \\
\text { al. }(2018)\end{array}$ \\
\hline Cetacean & Physeteridae & Sperm whale & 1 & 1 & $\mathrm{~N} / \mathrm{A}$ & 58 & 2012 & Spain & GIT & Macro & $\begin{array}{l}\text { de } \\
\text { Stephanis } \\
\text { et al. } \\
(2013)\end{array}$ \\
\hline Cetacean & Physeteridae & Sperm whale & 13 & 10 & $\mathrm{~N} / \mathrm{D}$ & N/D & $\begin{array}{l}2009- \\
2016\end{array}$ & $\begin{array}{l}\text { Mediterranean } \\
\text { Sea }\end{array}$ & GIT & Macro & $\begin{array}{l}\text { Panti et al. } \\
\text { (2019) }\end{array}$ \\
\hline Cetacean & Ziphiidae & $\begin{array}{l}\text { Cuvier's } \\
\text { beaked whale }\end{array}$ & 6 & $\begin{array}{l}1 \\
1\end{array}$ & $\mathrm{~N} / \mathrm{D}$ & N/D & $\begin{array}{l}2014- \\
2015\end{array}$ & Irish coast & GIT & $\begin{array}{l}\text { Macro } \\
\text { Micro }\end{array}$ & $\begin{array}{l}\text { Lusher et } \\
\text { al. (2018) }\end{array}$ \\
\hline Cetacean & Ziphiidae & $\begin{array}{l}\text { Sowerby's } \\
\text { beaked whale }\end{array}$ & 1 & 1 & N/A & 1 & 2009 & Irish coast & GIT & Macro & $\begin{array}{l}\text { Berrow et } \\
\text { al. }(2010)\end{array}$ \\
\hline Cetacean & Ziphiidae & $\begin{array}{l}\text { True's beaked } \\
\text { whale }\end{array}$ & 1 & 1 & N/A & N/D & 1997 & Irish coast & GIT & Macro & $\begin{array}{l}\text { Gassner et } \\
\text { al. }(2005)\end{array}$ \\
\hline Cetacean & Ziphiidae & $\begin{array}{l}\text { True's beaked } \\
\text { whale }\end{array}$ & 3 & 2 & $2-88$ & 90 & 2013 & Ireland & GIT & $\begin{array}{l}\text { Macro } \\
\& \\
\text { Micro }\end{array}$ & $\begin{array}{l}\text { Lusher et } \\
\text { al. (2015) }\end{array}$ \\
\hline Pinniped & Otariidae & $\begin{array}{l}\text { Antarctic fur } \\
\text { seal }\end{array}$ & N/D & 145 scats & $1-4$ & 165 & $\begin{array}{l}1990- \\
1997\end{array}$ & $\begin{array}{l}\text { Macquarie } \\
\text { Island }\end{array}$ & Scat & Micro & $\begin{array}{l}\text { Eriksson } \\
\text { and Burton } \\
\text { (2003) }\end{array}$ \\
\hline Pinniped & Otariidae & $\begin{array}{l}\text { Hooker's sea } \\
\text { lion }\end{array}$ & 51 scats & $\mathrm{N} / \mathrm{D}$ & N/D & 10 & $\begin{array}{l}1996- \\
1997\end{array}$ & $\begin{array}{l}\text { Macquarie } \\
\text { Island }\end{array}$ & Scat & Micro & $\begin{array}{l}\text { McMahon } \\
\text { et al. } \\
\text { (1999) }\end{array}$ \\
\hline Pinniped & Otariidae & $\begin{array}{l}\text { Northern fur } \\
\text { seal }\end{array}$ & 44 scats & $\begin{array}{l}24 \\
\text { fragments } \\
18 \text { fibres }\end{array}$ & $\mathrm{N} / \mathrm{D}$ & 584 & 2015 & $\begin{array}{l}\text { Alaska } \\
\text { California }\end{array}$ & Scat & Micro & $\begin{array}{l}\text { Donohue et } \\
\text { al. (2019) }\end{array}$ \\
\hline
\end{tabular}




\begin{tabular}{|c|c|c|c|c|c|c|c|c|c|c|c|}
\hline Pinniped & Otariidae & $\begin{array}{l}\text { South } \\
\text { American fur } \\
\text { seal }\end{array}$ & 133 & 10 & $1-2$ & 13 & $\begin{array}{l}1994- \\
2015\end{array}$ & $\begin{array}{l}\text { Northern } \\
\text { Argentina } \\
\text { Southern } \\
\text { Brazil }\end{array}$ & Stomach & Macro & $\begin{array}{l}\text { Denuncio } \\
\text { et al. } \\
(2017)\end{array}$ \\
\hline Pinniped & Phocidae & Grey seal & 13 & 13 & $13-71$ & 363 & $\begin{array}{l}2012- \\
2014\end{array}$ & South Ireland & Intestine & Micro & $\begin{array}{l}\text { Hernandez- } \\
\text { Milian et } \\
\text { al. (2019) }\end{array}$ \\
\hline Pinniped & Phocidae & Grey seal & 123 & 2 & 1 & 2 & $\begin{array}{l}1990- \\
2014\end{array}$ & $\begin{array}{l}\text { North and } \\
\text { Baltic Seas }\end{array}$ & GIT & Macro & $\begin{array}{l}\text { Unger et } \\
\text { al. (2017) }\end{array}$ \\
\hline Pinniped & Phocidae & Grey seal & 3 & 3 & $4-8$ & 18 & $\begin{array}{l}2016- \\
2017\end{array}$ & $\begin{array}{l}\text { United } \\
\text { Kingdom }\end{array}$ & GIT & Micro & $\begin{array}{l}\text { Nelms et } \\
\text { al. (2019) }\end{array}$ \\
\hline Pinniped & Phocidae & Grey seal & $\begin{array}{l}31 \text { (sub- } \\
\text { sampled) }\end{array}$ & 15 & $0-4$ & 26 & N/A & $\begin{array}{l}\text { Cornish Seal } \\
\text { Sanctuary in } \\
\text { Gweek, } \\
\text { Cornwall, UK }\end{array}$ & Scat & Micro & $\begin{array}{l}\text { Nelms et } \\
\text { al. }(2018)\end{array}$ \\
\hline Pinniped & Phocidae & Harbour seal & $\begin{array}{l}107 \\
\text { stomachs } \\
100 \\
\text { intestines } \\
125 \text { scats }\end{array}$ & $\begin{array}{l}12 \\
1 \\
0\end{array}$ & $\begin{array}{l}1-8 \\
\mathrm{~N} / \mathrm{A}\end{array}$ & $\begin{array}{l}28 \\
7\end{array}$ & $\begin{array}{l}2001- \\
2010\end{array}$ & $\begin{array}{l}\text { The } \\
\text { Netherlands }\end{array}$ & $\begin{array}{l}\text { Stomach } \\
\text { GIT } \\
\text { Scat }\end{array}$ & Micro & $\begin{array}{l}\text { Bravo } \\
\text { Rebolledo } \\
\text { et al. } \\
(2013)\end{array}$ \\
\hline Pinniped & Phocidae & Harbour seal & 4 & 4 & $1-7$ & 17 & $\begin{array}{l}2014- \\
2016\end{array}$ & $\begin{array}{l}\text { United } \\
\text { Kingdom }\end{array}$ & GIT & Micro & $\begin{array}{l}\text { Nelms et } \\
\text { al. (2019) }\end{array}$ \\
\hline Pinniped & Phocidae & Harbour seal & 951 & 8 & $1-3$ & 11 & $\begin{array}{l}1990- \\
2014\end{array}$ & $\begin{array}{l}\text { North and } \\
\text { Baltic Seas }\end{array}$ & GIT & Macro & $\begin{array}{l}\text { Unger et } \\
\text { al. (2017) }\end{array}$ \\
\hline Pinniped & Phocidae & $\begin{array}{l}\text { Mediterranean } \\
\text { monk seal }\end{array}$ & 2 & 1 & $\mathrm{~N} / \mathrm{A}$ & 1 & $\begin{array}{l}1999- \\
2001\end{array}$ & Aegean Sea & Stomach & Macro & $\begin{array}{l}\text { Salman et } \\
\text { al. }(2001)\end{array}$ \\
\hline Sirenia & Trichechidae & $\begin{array}{l}\text { Antillean } \\
\text { manatee }\end{array}$ & $40^{*}$ & 4 & N/D & N/D & $\begin{array}{l}1994- \\
2015\end{array}$ & Brazil & N/D & N/D & $\begin{array}{l}\text { Attademo } \\
\text { et al. } \\
(2015)\end{array}$ \\
\hline Sirenia & Trichechidae & $\begin{array}{l}\text { Florida } \\
\text { manatee }\end{array}$ & 439 & 63 & $1-14$ & $\mathrm{~N} / \mathrm{D}$ & $\begin{array}{l}1978- \\
1986\end{array}$ & SE U.S.A. & GIT & $\begin{array}{l}\text { Macro } \\
\& \\
\text { Micro } \\
\end{array}$ & $\begin{array}{l}\text { Beck and } \\
\text { Barros } \\
(1991)\end{array}$ \\
\hline
\end{tabular}

$\mathrm{N} / \mathrm{D}=$ Not determined or indicated in the literature

$\mathrm{N} / \mathrm{A}=$ Not applicable to the study

* Specimens released as a result of reintroduction program 


\section{B. Seal Sample Collection and Dissection Data}

Table 7.2: Supplementary data including field measurements and dissection data of collected seal.

\begin{tabular}{|c|c|c|c|c|c|c|c|c|c|c|}
\hline $\begin{array}{l}\text { Sample } \\
\text { ID }\end{array}$ & Community & Species & Sex & Year & Month & $\begin{array}{l}\text { Length } \\
\text { (cm) }\end{array}$ & $\begin{array}{l}\text { Age } \\
\text { Estimate }\end{array}$ & $\begin{array}{l}\text { Stomach } \\
\text { weight (g) }\end{array}$ & $\begin{array}{l}\text { Stomach } \\
\text { contents (g) }\end{array}$ & Stomach contents \\
\hline $\begin{array}{l}\text { ARAR- } \\
08-0584\end{array}$ & Arviat & Bearded Seal & $\bar{M}$ & 2008 & NA & 247.5 & 9 & 1855 & 268 & Roundworms \\
\hline $\begin{array}{l}\text { ARAR- } \\
08-0598\end{array}$ & Arviat & Ringed Seal & $\mathrm{M}$ & 2008 & October & 82.0 & 0 & 241 & 34 & Unknown \\
\hline $\begin{array}{l}\text { ARAR- } \\
08-0599\end{array}$ & Arviat & Ringed Seal & $\mathrm{F}$ & 2008 & October & 86.0 & 0 & 191 & 1 & Unknown \\
\hline $\begin{array}{l}\text { ARAR- } \\
08-0600\end{array}$ & Arviat & Ringed Seal & M & 2008 & October & 100.0 & 0 & 223 & 0 & Empty \\
\hline $\begin{array}{l}\text { ARAR- } \\
08-0601\end{array}$ & Arviat & Ringed Seal & M & 2008 & October & 111.0 & 29 & 293 & 0 & Empty \\
\hline $\begin{array}{l}\text { ARAR- } \\
08-0602\end{array}$ & Arviat & Harbour Seal & $\mathrm{M}$ & 2008 & October & 94.0 & 0 & 518 & 96 & Fish \\
\hline $\begin{array}{l}\text { ARAR- } \\
08-0603\end{array}$ & Arviat & Ringed Seal & $\mathrm{F}$ & 2008 & October & 110.0 & 0 & 252 & 1 & Unknown \\
\hline $\begin{array}{l}\text { ARAR- } \\
08-0604\end{array}$ & Arviat & Ringed Seal & $\mathrm{F}$ & 2008 & October & 120.0 & 6 & 391 & 0 & Empty \\
\hline $\begin{array}{l}\text { ARAR- } \\
08-0605\end{array}$ & Arviat & Ringed Seal & $\mathrm{F}$ & 2008 & October & 120.0 & 27 & 448 & 0 & Empty \\
\hline $\begin{array}{l}\text { ARAR- } \\
08-0606\end{array}$ & Arviat & Ringed Seal & $\mathrm{M}$ & 2008 & October & 97.0 & 0 & 281 & 8 & Roundworms \\
\hline
\end{tabular}




\begin{tabular}{|c|c|c|c|c|c|c|c|c|c|c|}
\hline $\begin{array}{l}\text { ARAR- } \\
08-0607\end{array}$ & Arviat & Ringed Seal & $\mathrm{F}$ & 2008 & October & 107.0 & 14 & 356 & 0 & Empty \\
\hline $\begin{array}{l}\text { ARAR- } \\
08-0608\end{array}$ & Arviat & Ringed Seal & UK & 2008 & October & 77.0 & 0 & 177 & 0 & Empty \\
\hline $\begin{array}{l}\text { ARAR- } \\
\text { 08-0609 }\end{array}$ & Arviat & Ringed Seal & $\mathrm{F}$ & 2008 & October & 81.0 & 0 & 171 & 7 & Fish \\
\hline $\begin{array}{l}\text { ARAR- } \\
08-0610\end{array}$ & Arviat & Ringed Seal & $\mathrm{F}$ & 2008 & October & 96.0 & 0 & 612 & 403 & Kelp \\
\hline $\begin{array}{l}\text { ARAR- } \\
08-0611\end{array}$ & Arviat & Ringed Seal & $\mathrm{F}$ & 2008 & October & 82.0 & 0 & 153 & 0 & Empty \\
\hline $\begin{array}{l}\text { ARAR- } \\
08-0612\end{array}$ & Arviat & Ringed Seal & $\mathrm{F}$ & 2008 & October & 100.0 & 1 & 247 & 7 & Unknown \\
\hline $\begin{array}{l}\text { ARAR- } \\
08-0613\end{array}$ & Arviat & Bearded Seal & M & 2008 & NA & 165.0 & 1 & 2046 & 816 & Fish \\
\hline $\begin{array}{l}\text { ARAR- } \\
08-0614\end{array}$ & Arviat & Bearded Seal & $\mathrm{M}$ & 2008 & NA & 236.3 & 15 & 6210 & 3446 & Rocks \\
\hline $\begin{array}{l}\text { ARAR- } \\
08-0615\end{array}$ & Arviat & Bearded Seal & M & 2008 & November & 215.0 & 6 & 1664 & 65 & Roundworms \\
\hline $\begin{array}{l}\text { ARAR- } \\
08-0618\end{array}$ & Arviat & Bearded Seal & $\mathrm{F}$ & 2008 & November & 211.9 & 4 & 2400 & 185 & Roundworms \\
\hline $\begin{array}{l}\text { ARAR- } \\
08-0622\end{array}$ & Arviat & Ringed Seal & M & 2008 & November & 107.0 & 4 & 267 & 0 & Empty \\
\hline $\begin{array}{l}\text { ARAR- } \\
08-0623\end{array}$ & Arviat & Ringed Seal & M & 2008 & November & 125.0 & 7 & 837 & 17 & Fish \\
\hline $\begin{array}{l}\text { ARAR- } \\
08-0626\end{array}$ & Arviat & Ringed Seal & $\mathrm{F}$ & 2008 & November & 84.0 & 0 & 219 & 0 & Empty \\
\hline
\end{tabular}




\begin{tabular}{|c|c|c|c|c|c|c|c|c|c|c|}
\hline $\begin{array}{l}\text { ARAR- } \\
08-0627\end{array}$ & Arviat & Ringed Seal & $\mathrm{F}$ & 2008 & November & 117.0 & 20 & 383 & 0 & Empty \\
\hline $\begin{array}{l}\text { ARAR- } \\
\text { 08-0628 }\end{array}$ & Arviat & Ringed Seal & M & 2008 & November & 116.0 & 21 & 400 & 0 & Empty \\
\hline $\begin{array}{l}\text { ARAR- } \\
\text { 08-0629 }\end{array}$ & Arviat & Ringed Seal & $\mathrm{F}$ & 2008 & November & 112.0 & 2 & 316 & 9 & Kelp \\
\hline $\begin{array}{l}\text { ARAR- } \\
08-0630\end{array}$ & Arviat & Ringed Seal & $\mathrm{F}$ & 2008 & November & 102.0 & 3 & 260 & 0 & Empty \\
\hline $\begin{array}{l}\text { ARAR- } \\
08-0631\end{array}$ & Arviat & Ringed Seal & M & 2008 & November & 104.0 & 0 & 224 & 8 & Euphausiids \\
\hline $\begin{array}{l}\text { ARAR- } \\
\text { 08-0632 }\end{array}$ & Arviat & Ringed Seal & $\mathrm{F}$ & 2008 & November & 100.0 & 1 & 200 & 0 & Empty \\
\hline $\begin{array}{l}\text { ARAR- } \\
08-0633\end{array}$ & Arviat & Ringed Seal & M & 2008 & November & 108.0 & 14 & 400 & 4 & Unknown \\
\hline $\begin{array}{l}\text { ARAR- } \\
\text { 08-0634 }\end{array}$ & Arviat & Ringed Seal & $\mathrm{F}$ & 2008 & November & 112.0 & 2 & 235 & 0 & Empty \\
\hline $\begin{array}{l}\text { ARAR- } \\
08-0635\end{array}$ & Arviat & Ringed Seal & $\mathrm{F}$ & 2008 & November & 100.0 & 2 & 235 & 0 & Empty \\
\hline $\begin{array}{l}\text { ARAR- } \\
\text { 08-0636 }\end{array}$ & Arviat & Ringed Seal & M & 2008 & November & 90.0 & 0 & 167 & 0 & Empty \\
\hline $\begin{array}{l}\text { ARAR- } \\
\text { 08-0637 }\end{array}$ & Arviat & Ringed Seal & $\mathrm{F}$ & 2008 & November & 93.0 & 0 & 662 & 291 & Fish \\
\hline $\begin{array}{l}\text { ARAR- } \\
\text { 08-0638 }\end{array}$ & Arviat & Ringed Seal & M & 2008 & November & 121.0 & 19 & 313 & 0 & Empty \\
\hline $\begin{array}{l}\text { ARAR- } \\
08-0639\end{array}$ & Arviat & Ringed Seal & $\mathrm{F}$ & 2008 & November & 121.0 & 4 & 292 & 0 & Empty \\
\hline
\end{tabular}




\begin{tabular}{|c|c|c|c|c|c|c|c|c|c|c|}
\hline $\begin{array}{l}\text { ARAR- } \\
08-0640\end{array}$ & Arviat & Ringed Seal & M & 2008 & November & 108.0 & 6 & 322 & 0 & Empty \\
\hline $\begin{array}{l}\text { ARAR- } \\
08-0641\end{array}$ & Arviat & Ringed Seal & M & 2008 & November & 104.0 & 6 & 269 & 13 & Unknown \\
\hline $\begin{array}{l}\text { ARAR- } \\
18-0039\end{array}$ & Arviat & Ringed Seal & NA & 2018 & October & 139.0 & NA & 563 & 43 & Unknown \\
\hline $\begin{array}{l}\text { IQA- } \\
\text { RS-135 }\end{array}$ & Iqaluit & Ringed Seal & M & 2018 & August & 83.0 & Juvenile & 334 & 135 & Euphausiids \\
\hline $\begin{array}{l}\text { IQA- } \\
\text { RS-136 }\end{array}$ & Iqaluit & Ringed Seal & M & 2018 & August & 84.0 & YOY & 389 & 188 & Euphausiids \\
\hline $\begin{array}{l}\text { IQA- } \\
\text { RS-140 }\end{array}$ & Iqaluit & Ringed Seal & $\mathrm{F}$ & 2018 & September & 87.0 & YOY & 408 & 163 & Euphausiids \\
\hline $\begin{array}{l}\text { IQA- } \\
\text { RS-141 }\end{array}$ & Iqaluit & Ringed Seal & $\mathrm{F}$ & 2018 & September & 97.0 & YOY & 328 & 114 & Euphausiids \\
\hline $\begin{array}{l}\text { IQA- } \\
\text { RS-142 }\end{array}$ & Iqaluit & Ringed Seal & M & 2018 & September & 88.0 & YOY & 200 & 0 & Empty \\
\hline $\begin{array}{l}\text { IQA- } \\
\text { RS-143 }\end{array}$ & Iqaluit & Ringed Seal & M & 2018 & September & 85.0 & YOY & 374 & 208 & Euphausiids \\
\hline $\begin{array}{l}\text { IQA- } \\
\text { RS-144 }\end{array}$ & Iqaluit & Ringed Seal & $\mathrm{F}$ & 2018 & September & 100.0 & YOY & 496 & 212 & Euphausiids \\
\hline $\begin{array}{l}\text { IQA- } \\
\text { RS-145 }\end{array}$ & Iqaluit & Ringed Seal & M & 2018 & September & 90.0 & YOY & 636 & 445 & Euphausiids \\
\hline $\begin{array}{l}\text { IQA- } \\
\text { RS-187 }\end{array}$ & Iqaluit & Ringed Seal & $\mathrm{F}$ & 2018 & September & 97.0 & YOY & 490 & 311 & Euphausiids \\
\hline $\begin{array}{l}\text { IQA- } \\
\text { RS-188 }\end{array}$ & Iqaluit & Ringed Seal & M & 2018 & September & 97.0 & YOY & 521 & 264 & Euphausiids \\
\hline
\end{tabular}




\begin{tabular}{|c|c|c|c|c|c|c|c|c|c|c|}
\hline $\begin{array}{l}\text { IQA- } \\
\text { RS-189 }\end{array}$ & Iqaluit & Ringed Seal & M & 2018 & September & NA & Juvenile & 504 & 226 & Euphausiids \\
\hline $\begin{array}{l}\text { IQA- } \\
\text { RS-190 }\end{array}$ & Iqaluit & Ringed Seal & M & 2018 & September & 87.0 & YOY & 327 & 107 & Euphausiids \\
\hline $\begin{array}{l}\text { IQA- } \\
\text { RS-192 }\end{array}$ & Iqaluit & Ringed Seal & $\mathrm{F}$ & 2018 & September & NA & YOY & 210 & 0 & Empty \\
\hline $\begin{array}{l}\text { IQA- } \\
\text { RS-194 }\end{array}$ & Iqaluit & Ringed Seal & M & 2018 & September & NA & Juvenile & 317 & 75 & Unknown \\
\hline $\begin{array}{l}\text { IQA- } \\
\text { RS-203 }\end{array}$ & Iqaluit & Ringed Seal & M & 2018 & September & 91.0 & YOY & 579 & 323 & Euphausiids \\
\hline $\begin{array}{l}\text { IQA- } \\
\text { RS-204 }\end{array}$ & Iqaluit & Ringed Seal & M & 2018 & September & 94.0 & YOY & 422 & 31 & Euphausiids \\
\hline $\begin{array}{l}\text { IQA- } \\
\text { RS-205 }\end{array}$ & Iqaluit & Ringed Seal & M & 2018 & September & 85.0 & YOY & 322 & 95 & Euphausiids \\
\hline $\begin{array}{l}\text { IQA- } \\
\text { RS-206 }\end{array}$ & Iqaluit & Ringed Seal & $\mathrm{F}$ & 2018 & September & 121.0 & Adult & 412 & 55 & Euphausiids \\
\hline $\begin{array}{l}\text { IQA-19- } \\
01\end{array}$ & Iqaluit & Ringed Seal & M & 2019 & September & 70.0 & YOY & 200 & 30 & Euphausiids \\
\hline $\begin{array}{l}\text { IQA-19- } \\
02\end{array}$ & Iqaluit & Ringed Seal & M & 2019 & September & 110.0 & Juvenile & 400 & 60 & Euphausiids \\
\hline $\begin{array}{l}\text { ARRB- } \\
08-0036\end{array}$ & Naujaat & Ringed Seal & UK & 2008 & September & 120.3 & 2 & 366 & 236 & Euphausiids \\
\hline $\begin{array}{l}\text { ARRB- } \\
08-0037\end{array}$ & Naujaat & Ringed Seal & M & 2008 & September & 116.8 & 3 & 356 & 85 & Euphausiids \\
\hline $\begin{array}{l}\text { ARRB- } \\
08-0038\end{array}$ & Naujaat & Ringed Seal & M & 2008 & September & 109.2 & 3 & 300 & 14 & Euphausiids \\
\hline
\end{tabular}




\begin{tabular}{|c|c|c|c|c|c|c|c|c|c|c|}
\hline $\begin{array}{l}\text { ARRB- } \\
08-0039\end{array}$ & Naujaat & Ringed Seal & $\mathrm{M}$ & 2008 & September & 105.4 & 1 & 461 & 229 & Roundworms \\
\hline $\begin{array}{l}\text { ARRB- } \\
08-0044\end{array}$ & Naujaat & Ringed Seal & $\mathrm{F}$ & 2008 & October & 132.1 & 9 & 532 & 0 & Empty \\
\hline $\begin{array}{l}\text { ARRB- } \\
08-0046\end{array}$ & Naujaat & Ringed Seal & $\mathrm{M}$ & 2008 & September & 165.0 & 29 & 1360 & 189 & Fish \\
\hline $\begin{array}{l}\text { ARRB- } \\
08-0047\end{array}$ & Naujaat & Ringed Seal & $\mathrm{F}$ & 2008 & October & 218.4 & 0 & 222 & 51 & Euphausiids \\
\hline $\begin{array}{l}\text { ARRB- } \\
08-0050\end{array}$ & Naujaat & Ringed Seal & $\mathrm{M}$ & 2008 & September & 99.1 & 2 & 280 & 40 & Euphausiids \\
\hline $\begin{array}{l}\text { ARRB- } \\
08-0061\end{array}$ & Naujaat & Ringed Seal & $\mathrm{M}$ & 2008 & October & 96.0 & 0 & 287 & 63 & Euphausiids \\
\hline $\begin{array}{l}\text { ARRB- } \\
08-0062\end{array}$ & Naujaat & Ringed Seal & $\mathrm{F}$ & 2008 & October & 86.5 & 0 & 300 & 110 & Euphausiids \\
\hline $\begin{array}{l}\text { ARRB- } \\
08-0063\end{array}$ & Naujaat & Ringed Seal & $\mathrm{F}$ & 2008 & October & 141.0 & 18 & 907 & 308 & Fish \\
\hline $\begin{array}{l}\text { ARRB- } \\
08-0071\end{array}$ & Naujaat & Ringed Seal & $\mathrm{F}$ & 2008 & October & 132.0 & 8 & 555 & 248 & Euphausiids \\
\hline $\begin{array}{l}\text { ARRB- } \\
08-0072\end{array}$ & Naujaat & Ringed Seal & $\mathrm{F}$ & 2008 & September & 112.0 & 4 & 572 & 242 & Euphausiids \\
\hline $\begin{array}{l}\text { ARRB- } \\
08-0075\end{array}$ & Naujaat & Ringed Seal & $\mathrm{M}$ & 2008 & October & 144.8 & 14 & 604 & 273 & Euphausiids \\
\hline $\begin{array}{l}\text { ARRB- } \\
08-0086\end{array}$ & Naujaat & Ringed Seal & $\mathrm{F}$ & 2008 & October & 138.2 & 14 & 516 & 186 & Euphausiids \\
\hline $\begin{array}{l}\text { ARRB- } \\
08-0092\end{array}$ & Naujaat & Ringed Seal & $\mathrm{F}$ & 2008 & October & 105.0 & 4 & 373 & 136 & Euphausiids \\
\hline
\end{tabular}




\begin{tabular}{|c|c|c|c|c|c|c|c|c|c|c|}
\hline $\begin{array}{l}\text { ARRB- } \\
08-0094\end{array}$ & Naujaat & Ringed Seal & M & 2008 & October & 96.5 & 0 & 525 & 260 & Fish/Euphausiids \\
\hline $\begin{array}{l}\text { ARRB- } \\
08-0097\end{array}$ & Naujaat & Ringed Seal & $\mathrm{F}$ & 2008 & October & 90.2 & 0 & 149 & 0 & Empty \\
\hline $\begin{array}{l}\text { ARRB- } \\
08-0100\end{array}$ & Naujaat & Ringed Seal & M & 2008 & October & NA & 0 & 263 & 0 & Empty \\
\hline $\begin{array}{l}\text { ARRB- } \\
08-0108\end{array}$ & Naujaat & Ringed Seal & M & 2008 & September & 105.0 & 1 & 350 & 117 & Euphausiids \\
\hline $\begin{array}{l}\text { ARRB- } \\
08-0110\end{array}$ & Naujaat & Ringed Seal & $\mathrm{F}$ & 2008 & September & 114.0 & 15 & 437 & 127 & Euphausiids \\
\hline $\begin{array}{l}\text { ARRB- } \\
08-0116\end{array}$ & Naujaat & Ringed Seal & $\mathrm{M}$ & 2008 & September & 131.7 & 10 & 733 & 394 & Euphausiids \\
\hline $\begin{array}{l}\text { ARRB- } \\
08-0117\end{array}$ & Naujaat & Ringed Seal & M & 2008 & October & 127.0 & 24 & 562 & 188 & Euphausiids \\
\hline $\begin{array}{l}\text { ARRB- } \\
08-0121\end{array}$ & Naujaat & Ringed Seal & $\mathrm{F}$ & 2008 & September & 102.0 & 0 & 350 & 135 & Fish/Euphausiids \\
\hline $\begin{array}{l}\text { ARRB- } \\
08-0122\end{array}$ & Naujaat & Ringed Seal & $\mathrm{F}$ & 2008 & September & 124.0 & 30 & 344 & 0 & Empty \\
\hline $\begin{array}{l}\text { ARRB- } \\
08-0124\end{array}$ & Naujaat & Ringed Seal & M & 2008 & October & 133.0 & 11 & 596 & 166 & Euphausiids \\
\hline $\begin{array}{l}\text { ARRB- } \\
08-0125\end{array}$ & Naujaat & Ringed Seal & $\mathrm{F}$ & 2008 & September & 130.0 & 23 & 619 & 250 & Fish \\
\hline $\begin{array}{l}\text { ARRB- } \\
08-0126\end{array}$ & Naujaat & Ringed Seal & M & 2008 & October & 96.8 & 0 & 191 & 0 & Empty \\
\hline $\begin{array}{l}\text { ARRB- } \\
08-0127\end{array}$ & Naujaat & Ringed Seal & M & 2008 & September & 119.0 & 5 & 339 & 84 & Euphausiids \\
\hline
\end{tabular}




\begin{tabular}{|c|c|c|c|c|c|c|c|c|c|c|}
\hline $\begin{array}{l}\text { ARRB- } \\
08-0130\end{array}$ & Naujaat & Ringed Seal & M & 2008 & October & 92.0 & 0 & 181 & 0 & Euphausiids \\
\hline $\begin{array}{l}\text { ARRB- } \\
08-0133\end{array}$ & Naujaat & Ringed Seal & $\mathrm{F}$ & 2008 & October & 126.0 & 4 & 429 & 27 & Roundworms \\
\hline $\begin{array}{l}\text { ARRB- } \\
08-0134\end{array}$ & Naujaat & Ringed Seal & $\mathrm{F}$ & 2008 & September & 121.9 & 18 & 175 & 110 & Roundworms \\
\hline $\begin{array}{l}\text { ARRB- } \\
08-0137\end{array}$ & Naujaat & Ringed Seal & $\mathrm{F}$ & 2008 & October & 117.0 & 5 & 510 & 172 & Euphausiids \\
\hline $\begin{array}{l}\text { ARRB- } \\
08-0143\end{array}$ & Naujaat & Ringed Seal & $\mathrm{F}$ & 2008 & September & 101.6 & 0 & 536 & 368 & Euphausiids \\
\hline $\begin{array}{l}\text { ARRB- } \\
08-0151\end{array}$ & Naujaat & Ringed Seal & M & 2008 & September & 127.0 & 22 & 510 & 63 & Euphausiids \\
\hline $\begin{array}{l}\text { ARRB- } \\
08-0154\end{array}$ & Naujaat & Ringed Seal & $\mathrm{M}$ & 2008 & October & 88.0 & 0 & 123 & 0 & Empty \\
\hline $\begin{array}{l}\text { ARRB- } \\
08-0157\end{array}$ & Naujaat & Ringed Seal & $\mathrm{F}$ & 2008 & October & 83.8 & 0 & 325 & 171 & Euphausiids \\
\hline $\begin{array}{l}\text { ARRB- } \\
08-0158\end{array}$ & Naujaat & Ringed Seal & $\mathrm{F}$ & 2008 & September & 113.0 & 1 & 323 & 82 & Euphausiids \\
\hline $\begin{array}{l}\text { ARSQ- } \\
07-0521\end{array}$ & Sanikiluaq & Ringed Seal & $\mathrm{M}$ & 2007 & February & 125.1 & 4 & 714 & 309 & Fish \\
\hline $\begin{array}{l}\text { ARSQ- } \\
07-0523\end{array}$ & Sanikiluaq & Ringed Seal & $\mathrm{F}$ & 2007 & January & 105.4 & 1 & 485 & 135 & Fish/Euphausiids \\
\hline $\begin{array}{l}\text { ARSQ- } \\
07-0524\end{array}$ & Sanikiluaq & Ringed Seal & $\mathrm{M}$ & 2007 & January & 104.1 & 0 & 305 & 47 & Fish \\
\hline $\begin{array}{l}\text { ARSQ- } \\
07-0525\end{array}$ & Sanikiluaq & Ringed Seal & $\mathrm{M}$ & 2007 & February & 111.8 & 2 & 236 & 22 & Euphausiids \\
\hline
\end{tabular}




\begin{tabular}{|c|c|c|c|c|c|c|c|c|c|c|}
\hline $\begin{array}{l}\text { ARSQ- } \\
07-0526\end{array}$ & Sanikiluaq & Ringed Seal & M & 2007 & February & 110.5 & 2 & 288 & 36 & Fish/Euphausiids \\
\hline $\begin{array}{l}\text { ARSQ- } \\
07-0528\end{array}$ & Sanikiluaq & Ringed Seal & M & 2007 & September & 81.3 & 0 & 557 & 368 & Fish \\
\hline $\begin{array}{l}\text { ARSQ- } \\
07-0530\end{array}$ & Sanikiluaq & Ringed Seal & $\mathrm{F}$ & 2007 & September & 82.0 & NA & 437 & 230 & Fish/Euphausiids \\
\hline $\begin{array}{l}\text { ARSQ- } \\
07-0533\end{array}$ & Sanikiluaq & Ringed Seal & $\mathrm{F}$ & 2007 & September & 89.0 & 0 & 400 & 210 & Fish/Euphausiids \\
\hline $\begin{array}{l}\text { ARSQ- } \\
07-0536\end{array}$ & Sanikiluaq & Ringed Seal & M & 2007 & February & 99.7 & 1 & 305 & 80 & Euphausiids \\
\hline $\begin{array}{l}\text { ARSQ- } \\
07-0538\end{array}$ & Sanikiluaq & Ringed Seal & M & 2007 & February & 100.3 & 3 & 263 & 40 & Fish/Euphausiids \\
\hline $\begin{array}{l}\text { ARSQ- } \\
07-0539\end{array}$ & Sanikiluaq & Ringed Seal & M & 2007 & February & 125.1 & 5 & 725 & 289 & Roundworms \\
\hline $\begin{array}{l}\text { ARSQ- } \\
07-0541\end{array}$ & Sanikiluaq & Ringed Seal & M & 2007 & February & 83.8 & 0 & 204 & 39 & Euphausiids \\
\hline $\begin{array}{l}\text { ARSQ- } \\
07-0545\end{array}$ & Sanikiluaq & Ringed Seal & M & 2007 & February & 96.5 & 2 & 300 & 138 & Euphausiids \\
\hline $\begin{array}{l}\text { ARSQ- } \\
07-0548\end{array}$ & Sanikiluaq & Ringed Seal & M & 2007 & February & 96.5 & 0 & 207 & 57 & Euphausiids \\
\hline $\begin{array}{l}\text { ARSQ- } \\
07-0549\end{array}$ & Sanikiluaq & Ringed Seal & $\mathrm{F}$ & 2007 & February & 97.2 & 0 & 433 & 258 & Fish \\
\hline $\begin{array}{l}\text { ARSQ- } \\
07-0552\end{array}$ & Sanikiluaq & Ringed Seal & M & 2007 & February & 94.0 & 0 & 223 & 16 & Fish \\
\hline $\begin{array}{l}\text { ARSQ- } \\
07-0553\end{array}$ & Sanikiluaq & Ringed Seal & $\mathrm{F}$ & 2007 & February & 99.1 & 0 & 235 & 35 & Euphausiids \\
\hline
\end{tabular}




\begin{tabular}{|c|c|c|c|c|c|c|c|c|c|c|}
\hline $\begin{array}{l}\text { ARSQ- } \\
07-0558\end{array}$ & Sanikiluaq & Ringed Seal & $\mathrm{F}$ & 2007 & January & 122.6 & 18 & 348 & 26 & Fish \\
\hline $\begin{array}{l}\text { ARSQ- } \\
07-0559\end{array}$ & Sanikiluaq & Ringed Seal & M & 2007 & February & 96.5 & 0 & 207 & 46 & Euphausiids \\
\hline $\begin{array}{l}\text { ARSQ- } \\
07-0560\end{array}$ & Sanikiluaq & Ringed Seal & $\mathrm{F}$ & 2007 & January & 94.0 & 0 & 190 & 20 & Euphausiids \\
\hline $\begin{array}{l}\text { ARSQ- } \\
07-0562\end{array}$ & Sanikiluaq & Ringed Seal & $\mathrm{F}$ & 2007 & February & 91.4 & 0 & 281 & 99 & Euphausiids \\
\hline $\begin{array}{l}\text { ARSQ- } \\
07-0563\end{array}$ & Sanikiluaq & Ringed Seal & $\mathrm{M}$ & 2007 & February & 83.8 & 0 & 152 & 13 & Fish/Euphausiids \\
\hline $\begin{array}{l}\text { ARSQ- } \\
07-0564\end{array}$ & Sanikiluaq & Ringed Seal & $\mathrm{F}$ & 2007 & February & 100.3 & 0 & 359 & 58 & Fish \\
\hline $\begin{array}{l}\text { ARSQ- } \\
07-0566\end{array}$ & Sanikiluaq & Ringed Seal & $\mathrm{M}$ & 2007 & February & 78.7 & 0 & 218 & 76 & Euphausiids \\
\hline $\begin{array}{l}\text { ARSQ- } \\
07-0568\end{array}$ & Sanikiluaq & Ringed Seal & $\mathrm{M}$ & 2007 & February & 81.3 & 2 & 500 & 243 & Euphausiids \\
\hline $\begin{array}{l}\text { ARSQ- } \\
07-0578\end{array}$ & Sanikiluaq & Bearded Seal & $\mathrm{M}$ & 2007 & October & 251.5 & 9 & 3359 & 1362 & Roundworms \\
\hline $\begin{array}{l}\text { ARSQ- } \\
07-0584\end{array}$ & Sanikiluaq & Ringed Seal & M & 2007 & October & 103.5 & 1 & 203 & 5 & Unknown \\
\hline $\begin{array}{l}\text { ARSQ- } \\
07-0590\end{array}$ & Sanikiluaq & Ringed Seal & $\mathrm{M}$ & 2007 & March & 116.8 & 8 & 350 & 109 & Unknown \\
\hline $\begin{array}{l}\text { ARSQ- } \\
07-0598\end{array}$ & Sanikiluaq & Ringed Seal & $\mathrm{F}$ & 2007 & February & 106.7 & 0 & 413 & 165 & Euphausiids \\
\hline $\begin{array}{l}\text { ARSQ- } \\
07-0608\end{array}$ & Sanikiluaq & Ringed Seal & $\mathrm{F}$ & 2007 & May & 129.5 & 18 & 880 & 144 & Fish \\
\hline
\end{tabular}




\begin{tabular}{|c|c|c|c|c|c|c|c|c|c|c|}
\hline $\begin{array}{l}\text { ARSQ- } \\
07-0614\end{array}$ & Sanikiluaq & Ringed Seal & $\mathrm{F}$ & 2007 & February & 81.6 & 0 & 174 & 28 & Euphausiids \\
\hline $\begin{array}{l}\text { ARSQ- } \\
07-0623\end{array}$ & Sanikiluaq & Ringed Seal & $\mathrm{M}$ & 2007 & February & 95.0 & 0 & 506 & 363 & Euphausiids \\
\hline $\begin{array}{l}\text { ARSQ- } \\
07-0630\end{array}$ & Sanikiluaq & Ringed Seal & $\mathrm{F}$ & 2007 & February & 90.0 & 0 & 396 & 243 & Euphausiids \\
\hline $\begin{array}{l}\text { ARSQ- } \\
07-0634\end{array}$ & Sanikiluaq & Ringed Seal & $\mathrm{M}$ & 2007 & March & 96.3 & 0 & 814 & 582 & Euphausiids \\
\hline $\begin{array}{l}\text { ARSQ- } \\
07-0522\end{array}$ & Sanikiluaq & Ringed Seal & $\mathrm{M}$ & 2008 & February & 125.4 & 4 & 332 & 7 & Fish/Euphausiids \\
\hline $\begin{array}{l}\text { ARSQ- } \\
08-0643\end{array}$ & Sanikiluaq & Ringed Seal & $\mathrm{M}$ & 2008 & June & 94.0 & 0 & 261 & 116 & Euphausiids \\
\hline $\begin{array}{l}\text { ARSQ- } \\
08-0644\end{array}$ & Sanikiluaq & Ringed Seal & $\mathrm{M}$ & 2008 & June & 88.9 & 0 & 214 & 34 & Roundworms \\
\hline $\begin{array}{l}\text { ARSQ- } \\
08-0645\end{array}$ & Sanikiluaq & Ringed Seal & $\mathrm{M}$ & 2008 & June & 101.6 & 1 & 428 & 232 & Fish \\
\hline $\begin{array}{l}\text { ARSQ- } \\
08-0651\end{array}$ & Sanikiluaq & Ringed Seal & $\mathrm{M}$ & 2008 & June & 128.3 & 21 & 380 & 0 & Empty \\
\hline $\begin{array}{l}\text { ARSQ- } \\
08-0652\end{array}$ & Sanikiluaq & Ringed Seal & $\mathrm{F}$ & 2008 & June & 111.8 & 4 & 891 & 574 & Fish \\
\hline $\begin{array}{l}\text { ARSQ- } \\
08-0653\end{array}$ & Sanikiluaq & Ringed Seal & $\mathrm{F}$ & 2008 & June & 96.5 & 2 & 176 & 0 & Empty \\
\hline $\begin{array}{l}\text { ARSQ- } \\
08-0654\end{array}$ & Sanikiluaq & Ringed Seal & $\mathrm{F}$ & 2008 & June & 134.6 & 20 & 639 & 0 & Empty \\
\hline $\begin{array}{l}\text { ARSQ- } \\
08-0661\end{array}$ & Sanikiluaq & Ringed Seal & $\mathrm{M}$ & 2008 & June & 124.5 & 28 & 562 & 0 & Empty \\
\hline
\end{tabular}




\begin{tabular}{lllllllllll}
$\begin{array}{l}\text { ARSQ- } \\
08-0662\end{array}$ & Sanikiluaq & Ringed Seal & M & 2008 & June & 121.9 & 18 & 395 & 102 & Euphausiids \\
$\begin{array}{l}\text { ARSQ- } \\
08-0663\end{array}$ & Sanikiluaq & Ringed Seal & F & 2008 & June & 105.4 & 6 & 538 & 181 & Fish \\
\hline
\end{tabular}




\section{Bird GIT and Faecal Precursor Data}

Table 7.3: Counts and shape categories of plastics in gastrointestinal tracts and anthropogenic particles in guano samples for northern fulmars (NOFU) and thick-billed murres (TBMU).

\begin{tabular}{|c|c|c|c|c|c|c|c|c|c|c|c|c|c|c|c|}
\hline \multirow{2}{*}{ Bird ID } & \multirow{2}{*}{ Species } & \multirow{2}{*}{ Sex } & \multicolumn{7}{|c|}{ Plastics in GIT } & \multicolumn{6}{|c|}{ Anthropogenic Particles in Faecal Precursor } \\
\hline & & & $\mathbf{Y} / \mathbf{N}$ & $\#$ & Fibre & Fragment & Film & Foam & Other & $\mathbf{Y} / \mathbf{N}$ & $\#$ & Fibre & Fragment & Film & Foam \\
\hline $\begin{array}{l}\text { NOFU } \\
01\end{array}$ & NOFU & $\mathrm{F}$ & Y & 3 & 0 & 3 & 0 & 0 & 0 & $\mathrm{~N}$ & 0 & 0 & 0 & 0 & 0 \\
\hline $\begin{array}{l}\text { NOFU } \\
02\end{array}$ & NOFU & $\mathrm{F}$ & $\mathrm{N}$ & 0 & 0 & 0 & 0 & 0 & 0 & Y & 1 & 1 & 0 & 0 & 0 \\
\hline $\begin{array}{l}\text { NOFU } \\
03\end{array}$ & NOFU & $\mathrm{M}$ & $\mathrm{Y}$ & 1 & 0 & 1 & 0 & 0 & 0 & $\mathrm{~N}$ & 0 & 0 & 0 & 0 & 0 \\
\hline $\begin{array}{l}\text { NOFU } \\
04\end{array}$ & NOFU & $\mathrm{F}$ & $\mathrm{Y}$ & 2 & 0 & 2 & 0 & 0 & 0 & Y & 1 & 1 & 0 & 0 & 0 \\
\hline $\begin{array}{l}\text { NOFU } \\
05\end{array}$ & NOFU & $\mathrm{M}$ & $\mathrm{Y}$ & 1 & 0 & 1 & 0 & 0 & 0 & $\mathrm{Y}$ & 1 & 1 & 0 & 0 & 0 \\
\hline $\begin{array}{l}\text { NOFU } \\
06\end{array}$ & NOFU & F & Y & 4 & 1 & 3 & 0 & 0 & 0 & Y & 1 & 1 & 0 & 0 & 0 \\
\hline $\begin{array}{l}\text { NOFU } \\
07\end{array}$ & NOFU & $\mathrm{F}$ & $\mathrm{N}$ & 0 & 0 & 0 & 0 & 0 & 0 & Y & 2 & 2 & 0 & 0 & 0 \\
\hline $\begin{array}{l}\text { NOFU } \\
08\end{array}$ & NOFU & $\mathrm{F}$ & $\mathrm{N}$ & 0 & 0 & 0 & 0 & 0 & 0 & Y & 1 & 1 & 0 & 0 & 0 \\
\hline $\begin{array}{l}\text { NOFU } \\
09\end{array}$ & NOFU & $\mathrm{M}$ & Y & 2 & 0 & 1 & 1 & 0 & 0 & $\mathrm{~N}$ & 0 & 0 & 0 & 0 & 0 \\
\hline $\begin{array}{l}\text { NOFU } \\
10\end{array}$ & NOFU & $\mathrm{F}$ & Y & 2 & 0 & 2 & 0 & 0 & 0 & $\mathrm{~N}$ & 0 & 0 & 0 & 0 & 0 \\
\hline $\begin{array}{l}\text { NOFU } \\
11\end{array}$ & NOFU & $\mathrm{F}$ & $\mathrm{Y}$ & 3 & 0 & 3 & 0 & 0 & 0 & $\mathrm{Y}$ & 1 & 1 & 0 & 0 & 0 \\
\hline $\begin{array}{l}\text { NOFU } \\
12\end{array}$ & NOFU & $\mathrm{M}$ & $\mathrm{Y}$ & 1 & 0 & 1 & 0 & 0 & 0 & Y & 1 & 1 & 0 & 0 & 0 \\
\hline $\begin{array}{l}\text { NOFU } \\
13\end{array}$ & NOFU & $\mathrm{F}$ & $\mathrm{Y}$ & 3 & 0 & 3 & 0 & 0 & 0 & $\mathrm{~N}$ & 0 & 0 & 0 & 0 & 0 \\
\hline $\begin{array}{l}\text { NOFU } \\
14\end{array}$ & NOFU & $\mathrm{M}$ & $\mathrm{N}$ & 0 & 0 & 0 & 0 & 0 & 0 & $\mathrm{Y}$ & 3 & 2 & 1 & 0 & 0 \\
\hline
\end{tabular}




\begin{tabular}{|c|c|c|c|c|c|c|c|c|c|c|c|c|c|c|c|}
\hline $\begin{array}{l}\text { NOFU } \\
15\end{array}$ & NOFU & $\mathrm{F}$ & $\mathrm{Y}$ & 3 & 0 & 3 & 0 & 0 & 0 & $\mathrm{Y}$ & 4 & 4 & 0 & 0 & 0 \\
\hline $\begin{array}{l}\text { NOFU } \\
16\end{array}$ & NOFU & $\mathrm{F}$ & $\mathrm{Y}$ & 1 & 0 & 1 & 0 & 0 & 0 & $\mathrm{~N}$ & 0 & 0 & 0 & 0 & 0 \\
\hline $\begin{array}{l}\text { NOFU } \\
17\end{array}$ & NOFU & $\mathrm{M}$ & $\mathrm{N}$ & 0 & 0 & 0 & 0 & 0 & 0 & $\mathrm{~N}$ & 0 & 0 & 0 & 0 & 0 \\
\hline $\begin{array}{l}\text { NOFU } \\
18\end{array}$ & NOFU & $\mathrm{M}$ & $\mathrm{Y}$ & 4 & 0 & 1 & 3 & 0 & 0 & $\mathrm{Y}$ & 1 & 1 & 0 & 0 & 0 \\
\hline $\begin{array}{l}\text { NOFU } \\
19\end{array}$ & NOFU & M & $\mathrm{N}$ & 0 & 0 & 0 & 0 & 0 & 0 & NA & NA & NA & NA & NA & NA \\
\hline $\begin{array}{l}\text { NOFU } \\
20\end{array}$ & NOFU & $\mathrm{F}$ & $\mathrm{N}$ & 0 & 0 & 0 & 0 & 0 & 0 & $\mathrm{~N}$ & 0 & 0 & 0 & 0 & 0 \\
\hline $\begin{array}{l}\text { NOFU } \\
21\end{array}$ & NOFU & $\mathrm{M}$ & $\mathrm{N}$ & 0 & 0 & 0 & 0 & 0 & 0 & $\mathrm{~N}$ & 0 & 0 & 0 & 0 & 0 \\
\hline $\begin{array}{l}\text { NOFU } \\
22\end{array}$ & NOFU & $\mathrm{M}$ & $\mathrm{Y}$ & 3 & 0 & 3 & 0 & 0 & 0 & $\mathrm{~N}$ & 0 & 0 & 0 & 0 & 0 \\
\hline $\begin{array}{l}\text { NOFU } \\
23\end{array}$ & NOFU & $\mathrm{F}$ & $\mathrm{Y}$ & 2 & 0 & 1 & 0 & 0 & $1^{*}$ & NA & NA & NA & NA & NA & NA \\
\hline $\begin{array}{l}\text { NOFU } \\
24\end{array}$ & NOFU & $\mathrm{F}$ & $\mathrm{Y}$ & 3 & 0 & 3 & 0 & 0 & 0 & $\mathrm{Y}$ & 2 & 2 & 0 & 0 & 0 \\
\hline $\begin{array}{l}\text { NOFU } \\
25\end{array}$ & NOFU & $\mathrm{M}$ & $\mathrm{Y}$ & 1 & 0 & 1 & 0 & 0 & 0 & $\mathrm{~N}$ & 0 & 0 & 0 & 0 & 0 \\
\hline $\begin{array}{l}\text { NOFU } \\
27\end{array}$ & NOFU & $\mathrm{M}$ & Y & 6 & 0 & 6 & 0 & 0 & 0 & $\mathrm{Y}$ & 3 & 3 & 0 & 0 & 0 \\
\hline $\begin{array}{l}\text { NOFU } \\
28\end{array}$ & NOFU & $\mathrm{F}$ & Y & 3 & 0 & 3 & 0 & 0 & 0 & $\mathrm{~N}$ & 0 & 0 & 0 & 0 & 0 \\
\hline $\begin{array}{l}\text { NOFU } \\
29\end{array}$ & NOFU & $\mathrm{F}$ & $\mathrm{Y}$ & 1 & 0 & 1 & 0 & 0 & 0 & $\mathrm{Y}$ & 1 & 1 & 0 & 0 & 0 \\
\hline $\begin{array}{l}\text { NOFU } \\
30\end{array}$ & NOFU & $\mathrm{F}$ & Y & 1 & 0 & 1 & 0 & 0 & 0 & $\mathrm{Y}$ & 1 & 1 & 0 & 0 & 0 \\
\hline $\begin{array}{l}\text { TBMU } \\
01\end{array}$ & TBMU & $\mathrm{M}$ & $\mathrm{N}$ & 0 & 0 & 0 & 0 & 0 & 0 & $\mathrm{~N}$ & 0 & 0 & 0 & 0 & 0 \\
\hline $\begin{array}{l}\text { TBMU } \\
02\end{array}$ & TBMU & $\mathrm{M}$ & $\mathrm{N}$ & 0 & 0 & 0 & 0 & 0 & 0 & $\mathrm{~N}$ & 0 & 0 & 0 & 0 & 0 \\
\hline $\begin{array}{l}\text { TBMU } \\
03\end{array}$ & TBMU & $\mathrm{F}$ & $\mathrm{N}$ & 0 & 0 & 0 & 0 & 0 & 0 & $\mathrm{~N}$ & 0 & 0 & 0 & 0 & 0 \\
\hline
\end{tabular}




\begin{tabular}{|c|c|c|c|c|c|c|c|c|c|c|c|c|c|c|}
\hline $\begin{array}{l}\text { TBMU } \\
04\end{array}$ & TBMU & $\mathrm{F}$ & $\mathrm{N}$ & 0 & 0 & 0 & 0 & 0 & 0 & $\mathrm{~N}$ & 0 & 0 & 0 & 0 \\
\hline $\begin{array}{l}\text { TBMU } \\
05\end{array}$ & TBMU & M & $\mathrm{N}$ & 0 & 0 & 0 & 0 & 0 & 0 & $\mathrm{~N}$ & 0 & 0 & 0 & 0 \\
\hline $\begin{array}{l}\text { TBMU } \\
06\end{array}$ & TBMU & $\mathrm{F}$ & $\mathrm{N}$ & 0 & 0 & 0 & 0 & 0 & 0 & Y & 3 & 0 & 3 & 0 \\
\hline $\begin{array}{l}\text { TBMU } \\
07\end{array}$ & TBMU & M & $\mathrm{N}$ & 0 & 0 & 0 & 0 & 0 & 0 & Y & 1 & 0 & 1 & 0 \\
\hline $\begin{array}{l}\text { TBMU } \\
08\end{array}$ & TBMU & $\mathrm{M}$ & $\mathrm{N}$ & 0 & 0 & 0 & 0 & 0 & 0 & $\mathrm{~N}$ & 0 & 0 & 0 & 0 \\
\hline $\begin{array}{l}\text { TBMU } \\
09\end{array}$ & TBMU & $\mathrm{F}$ & $\mathrm{N}$ & 0 & 0 & 0 & 0 & 0 & 0 & $\mathrm{~N}$ & 0 & 0 & 0 & 0 \\
\hline $\begin{array}{l}\text { TBMU } \\
10\end{array}$ & TBMU & M & $\mathrm{N}$ & 0 & 0 & 0 & 0 & 0 & 0 & $\mathrm{~N}$ & 0 & 0 & 0 & 0 \\
\hline $\begin{array}{l}\text { TBMU } \\
11\end{array}$ & TBMU & $\mathrm{F}$ & $\mathrm{N}$ & 0 & 0 & 0 & 0 & 0 & 0 & $\mathrm{~N}$ & 0 & 0 & 0 & 0 \\
\hline $\begin{array}{l}\text { TBMU } \\
12\end{array}$ & TBMU & M & $\mathrm{N}$ & 0 & 0 & 0 & 0 & 0 & 0 & $\mathrm{~N}$ & 0 & 0 & 0 & 0 \\
\hline $\begin{array}{l}\text { TBMU } \\
13\end{array}$ & TBMU & $\mathrm{M}$ & $\mathrm{N}$ & 0 & 0 & 0 & 0 & 0 & 0 & $\mathrm{~N}$ & 0 & 0 & 0 & 0 \\
\hline $\begin{array}{l}\text { TBMU } \\
14\end{array}$ & TBMU & $\mathrm{M}$ & $\mathrm{N}$ & 0 & 0 & 0 & 0 & 0 & 0 & $\mathrm{~N}$ & 0 & 0 & 0 & 0 \\
\hline $\begin{array}{l}\text { TBMU } \\
15\end{array}$ & TBMU & M & $\mathrm{N}$ & 0 & 0 & 0 & 0 & 0 & 0 & $\mathrm{~N}$ & 0 & 0 & 0 & 0 \\
\hline $\begin{array}{l}\text { TBMU } \\
16\end{array}$ & TBMU & M & $\mathrm{N}$ & 0 & 0 & 0 & 0 & 0 & 0 & $\mathrm{~N}$ & 0 & 0 & 0 & 0 \\
\hline $\begin{array}{l}\text { TBMU } \\
17\end{array}$ & TBMU & $\mathrm{F}$ & $\mathrm{N}$ & 0 & 0 & 0 & 0 & 0 & 0 & $\mathrm{~N}$ & 0 & 0 & 0 & 0 \\
\hline $\begin{array}{l}\text { TBMU } \\
18\end{array}$ & TBMU & $\mathrm{M}$ & $\mathrm{N}$ & 0 & 0 & 0 & 0 & 0 & 0 & $\mathrm{Y}$ & 1 & 1 & 0 & 0 \\
\hline $\begin{array}{l}\text { TBMU } \\
19\end{array}$ & TBMU & M & $\mathrm{N}$ & 0 & 0 & 0 & 0 & 0 & 0 & $\mathrm{Y}$ & 4 & 3 & 0 & 0 \\
\hline $\begin{array}{l}\text { TBMU } \\
20\end{array}$ & TBMU & M & $\mathrm{N}$ & 0 & 0 & 0 & 0 & 0 & 0 & $\mathrm{~N}$ & 0 & 0 & 0 & 0 \\
\hline $\begin{array}{l}\text { TBMU } \\
21\end{array}$ & TBMU & $\mathrm{F}$ & $\mathrm{N}$ & 0 & 0 & 0 & 0 & 0 & 0 & $\mathrm{~N}$ & 0 & 0 & 0 & 0 \\
\hline
\end{tabular}




\begin{tabular}{|c|c|c|c|c|c|c|c|c|c|c|c|c|c|c|c|}
\hline TBMU & TBMU & M & $\mathrm{N}$ & 0 & 0 & 0 & 0 & 0 & 0 & $\mathrm{~N}$ & 0 & 0 & 0 & 0 & 0 \\
\hline & TBMU & $\mathrm{F}$ & $\mathrm{N}$ & 0 & 0 & 0 & 0 & 0 & 0 & $\mathrm{~N}$ & 0 & 0 & 0 & 0 & 0 \\
\hline & TBMU & M & $\mathrm{N}$ & 0 & 0 & 0 & 0 & 0 & 0 & $\mathrm{~N}$ & 0 & 0 & 0 & 0 & 0 \\
\hline & TBMU & $\mathrm{F}$ & $\mathrm{N}$ & 0 & 0 & 0 & 0 & 0 & 0 & $\mathrm{~N}$ & 0 & 0 & 0 & 0 & 0 \\
\hline & TBMU & M & $\mathrm{N}$ & 0 & 0 & 0 & 0 & 0 & 0 & $\mathrm{~N}$ & 0 & 0 & 0 & 0 & 0 \\
\hline & TBMU & M & $\mathrm{N}$ & 0 & 0 & 0 & 0 & 0 & 0 & $\mathrm{~N}$ & 0 & 0 & 0 & 0 & 0 \\
\hline & TBMU & M & $\mathrm{N}$ & 0 & 0 & 0 & 0 & 0 & 0 & Y & 1 & 1 & 0 & 0 & 0 \\
\hline 29 & TBMU & $\mathrm{F}$ & $\mathrm{N}$ & 0 & 0 & 0 & 0 & 0 & 0 & $\mathrm{~N}$ & 0 & 0 & 0 & 0 & 0 \\
\hline $\begin{array}{l}\text { TBMU } \\
30\end{array}$ & TBMU & $\mathrm{F}$ & $\mathrm{N}$ & 0 & 0 & 0 & 0 & 0 & 0 & $\mathrm{~N}$ & 0 & 0 & 0 & 0 & 0 \\
\hline
\end{tabular}

NOFU $=$ Northern fulmar

TBMU $=$ Thick-billed murre

$\mathrm{NA}=$ Not Available

* Band-aid found in GIT of NOFU 23 
Table 7.4: Shape, colour, and polymer classification of anthropogenic particles found in northern fulmar (NOFU) and thick-billed murre (TBMU) faecal precursors from colonies near Qikiqtarjuaq, NU.

\begin{tabular}{|c|c|c|c|c|c|c|c|}
\hline Bird ID & Species & Particle ID & Type & Colour & $\begin{array}{l}\text { Length } \\
(\mu \mathrm{m})\end{array}$ & $\begin{array}{l}\text { Width } \\
(\mu \mathrm{m})\end{array}$ & $\begin{array}{l}\text { Polymer } \\
\text { classification }\end{array}$ \\
\hline NOFU02 & NOFU & N02-20 & Fibre & Blue & 425.5 & & Synthetic dye \\
\hline NOFU04 & NOFU & N04-4 & Fibre & Blue & 303.9 & & $\begin{array}{l}\text { Anthropogenic } \\
\text { unknown }\end{array}$ \\
\hline NOFU05 & NOFU & N05-8 & Fibre & Blue & 1040.9 & & Synthetic dye \\
\hline NOFU06 & NOFU & N06-3 & Fibre & Blue & 1932.9 & & Polyester \\
\hline NOFU07 & NOFU & N07-15 & Fibre & Red & 574.5 & & $\begin{array}{l}\text { Anthropogenic } \\
\text { cellulosic }\end{array}$ \\
\hline NOFU07 & NOFU & N07-16 & Fibre & White & 4786.4 & & Polyester \\
\hline NOFU08 & NOFU & N08-17 & Fibre & Blue & 230.4 & & $\begin{array}{l}\text { Anthropogenic } \\
\text { cellulosic }\end{array}$ \\
\hline NOFU11 & NOFU & N11-50 & Fibre & White & 2617.5 & & Polyester \\
\hline NOFU12 & NOFU & N12-14 & Fibre & Blue & 603.2 & & Synthetic dye \\
\hline NOFU14 & NOFU & N14-7 & Fragment & Blue & 146.3 & 70.5 & Polyethylene \\
\hline NOFU14 & NOFU & N14-5 & Fibre & Blue & 167.8 & & Synthetic dye \\
\hline NOFU14 & NOFU & N14-6 & Fibre & Blue & 296.0 & & $\begin{array}{l}\text { Anthropogenic } \\
\text { unknown }\end{array}$ \\
\hline NOFU15 & NOFU & N15-11 & Fibre & Red & 539.3 & & $\begin{array}{l}\text { Anthropogenic } \\
\text { cellulosic }\end{array}$ \\
\hline NOFU15 & NOFU & N15-12 & Fibre & Red & 214.7 & & Synthetic dye \\
\hline NOFU15 & NOFU & N15-9 & Fibre & Blue & 817.6 & & Synthetic dye \\
\hline
\end{tabular}




\begin{tabular}{|c|c|c|c|c|c|c|c|}
\hline NOFU15 & NOFU & N15-10 & Fibre & Blue & 498.5 & & Polyester \\
\hline NOFU18 & NOFU & N18-43 & Fibre & Red & 297.8 & & $\begin{array}{l}\text { Anthropogenic } \\
\text { cellulosic }\end{array}$ \\
\hline NOFU24 & NOFU & $\mathrm{N} 24-31$ & Fibre & White & 838.5 & & Polyamide \\
\hline NOFU24 & NOFU & N24-32 & Fibre & White & 3382.4 & & Polyester \\
\hline NOFU27 & NOFU & N27-28 & Fibre & White & 1927.9 & & Polyester \\
\hline NOFU27 & NOFU & N27-1 & Fibre & Blue & 684.8 & & Synthetic dye \\
\hline NOFU27 & NOFU & $\mathrm{N} 27-2$ & Fibre & Blue & 2228.6 & & Synthetic dye \\
\hline NOFU29 & NOFU & N29-13 & Fibre & Black & 163.6 & & $\begin{array}{l}\text { Anthropogenic } \\
\text { cellulosic }\end{array}$ \\
\hline NOFU30 & NOFU & N30-18 & Fibre & Blue & 1340.7 & & Synthetic dye \\
\hline TBMU06 & TBMU & Т06-58 & Fragment & Blue & 95.8 & 66.7 & Polyethylene \\
\hline TBMU06 & TBMU & T06-59 & Fragment & Red & 41.7 & 33.4 & $\begin{array}{l}\text { Anthropogenic } \\
\text { unknown }\end{array}$ \\
\hline TBMU06 & TBMU & Т06-60 & Fragment & Grey & 223.5 & 139.6 & $\begin{array}{l}\text { Anthropogenic } \\
\text { unknown }\end{array}$ \\
\hline TBMU07 & TBMU & T07-56 & Fragment & Blue & 27.4 & 23.0 & Polyethylene \\
\hline TBMU18 & TBMU & T18-21 & Fibre & Blue & 1365.7 & & Synthetic dye \\
\hline TBMU19 & TBMU & T19-22 & Fibre & Blue & 1861.1 & & $\begin{array}{l}\text { Anthropogenic } \\
\text { unknown }\end{array}$ \\
\hline TBMU19 & TBMU & T19-23 & Fibre & Black & 272.5 & & $\begin{array}{l}\text { Anthropogenic } \\
\text { unknown }\end{array}$ \\
\hline TBMU19 & TBMU & T19-24 & Fibre & Black/White & 1992.4 & & Polyamide \\
\hline
\end{tabular}




\begin{tabular}{llllllll} 
TBMU19 & TBMU & T19-52 & Foam & Blue & 144.4 & 124.6 & Polyethylene \\
TBMU28 & TBMU & T28-25 & Fibre & Yellow & 2641.7 & Acrylic \\
\hline
\end{tabular}

